\title{
ForaminifERa CHEck LiSt AND the MAIN SPECIES Distribution IN THE AVEIRO Lagoon and Adjacent Continental Shelf (Portugal)
}

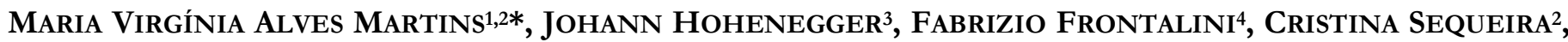 Paulo Miranda ${ }^{2,5}$, Maria ANTONieta da Conceição Rodrigues ${ }^{1}$, Wânia Duleba ${ }^{6}$, Lazaro LaUt ${ }^{7}$ and FERNANDO ROCHA ${ }^{2}$}

1 Universidade do Estado do Rio de Janeiro, UERJ, Faculdade de Geologia, Departamento de Estratigrafia e Paleontologia, Rio de Janeiro, RJ, Brazil

2 Universidade de Aveiro, Dpto. Geociências, GeoBioTec, CESAM, Aveiro, Portugal

3 Universität Wien, Geozentrum, Department of Palaeontology, Vienna, Austria.

4 Università degli Studi di Urbino "Carlo Bo", Dipartimento di Scienze Pure e Applicate (DiSPeA) Urbino, Italy

5 Direção-Geral do Território, Lisbon, Portugal

6 Universidade de São Paulo, Escola de Artes Ciências e Humanidades, São Paulo, SP, Brazil

7 Universidade Federal do Estado do Rio de Janeiro, UNIRIO, Laboratório de Micropaleontologia - LABMICRO, Rio de Janeiro, RJ, Brazil

*Corresponding Author, virginia.martins@ua.pt

Received on 11 December 2018

Received in revised form on 29 December 2018

Accepted on 2 January 2019

Editor: Sergio Bergamaschi, Universidade do Estado do Rio de Janeiro, Brazil
Citation:

Alves Martins, M.V., Hohenegger, J., Frontalini, F., Sequeira, C., Miranda, P., Rodrigues, M.A.C., Duleba, W., Laut, L., Rocha, F., 2019. Foraminifera check list and the main species distribution in the Aveiro Lagoon and Adjacent Continental Shelf (Portugal). Journal of Sedimentary Environments, 4 (1): 1-52.

\section{Abstract}

This work is based on a compilation of benthic foraminiferal data collected in the Aveiro Lagoon and in the adjacent continental shelf and upper slope (center of Portugal). It intends to provide an overall analysis from transitional to the outer continental shelf of the occurrence and distribution of species in living and to present updated taxonomic data and illustrations of most of the species found in the in the Aveiro Lagoon and in the adjacent continental shelf including in total assemblages. Correspondence analysis (CA) and Principal Components Analysis (PCA) interpreted as depth functions allow us to identify the main species in different ecoenvironments and sectors of the study area. The most unusual living assemblage was documented in the lagoon inlet under very strong tidal currents activity, composed

\section{Introduction}

With the increasing interest in environmental issues, methodologies to determine and control marine pollution over time have been the object of active research. Numerous studies have demonstrated the value of different organisms in evaluating the environmental quality and can be therefore used as bioindicators. A bioindicator can be defined as an organism or set of organisms, biological components, cells, biochemical processes, structures, biological functions, that mostly by the following species (both in living and total assemblages): Rotaliammina concava, Lepidodeuterammina ochracea, Quinqueloculina seminula, Gavelinopsis praegeri, Paratrochammina haynesi, Remaneica belgolandica and Remaneicella gonzalezi. The distribution patterns of some Trochamminidae and Remaneicidae species whose ecology and distribution pattern are poorly known, have proved to be a marker of more or less hydrodynamic and stable/unstable environments in coastal and transitional marine environments.

Keywords: Ecology. Taxonomy. Digital Imaging. Statistical Analysis Transitional and Marine Environments.

allow to characterize the state of an ecosystem and to show early natural and/or anthropic modifications (Livingstone, 1993). Indicators at different levels of biological organization provide complementary information necessary for ecological risk assessment (Cairns and Pratt, 1993). In order to be considered as a bioindicator, the organism would be easy to identify and to collect, have well-known ecological and biological characteristics, and be sensitive to environmental change. 
Many species of benthic foraminifera are known to have these characteristics (Murray, 2006; Schönfeld et al., 2012). They are sensitive to variations in the environment in which they live (Mendes et al., 2010; Charrieau et al., 2018), to disturbance of sedimentary environment (Koho et al., 2007), to low dissolved oxygen concentrations and $\mathrm{pH}$ (Sen Gupta and Machain-Castillo, 1993; Jorissen et al.,1995), to food quantity and quality (Koho et al, 2008; Martins et al., 2015a; Dessandier et al., 2015, 2016) and to pollution (Martins et al., 2010, 2013).

Foraminifera are bioindicators of great interest because they have short life cycles and react quickly to environmental changes (Debenay et al., 2000), thus can be used to describe and monitor natural or human-induced modifications (Bladin, 1986). Being small and abundant, they can be found in large numbers, in small amount of sediment, enabling statistically reliable and economically attractive studies (Scott et al., 2001). In light of it, foraminifera have been frequently used as bioindicators of polluted environments by the discharge of domestic or industrial sewage, fertilizers, aquaculture, trace elements, oil contamination and petroleum (Seiglie, 1975; Alve 1999, 2003; Samir, 2000; Debenay et al., 2001; Scott et al., 2001; Geslin et al., 2002; Romano et al., 2008; Mojtahid et al., 2008, among others) and in palaeoceanographic and paleoenvironmental studies (e.g. van der Zwaan, 1999; Leorri et al., 2011; Fatela et al., 2014; Quintela et al., 2016; Guo et al., 2017) in many regions of the global ocean.

In the Portuguese continental margin, several studies have been carried out to study the foraminiferal distribution and the processes influencing their distribution (Levy et al., 1993, 1995; Mendes et al., 2004; Martins et al., 2012, 2015b; Dessandier et al., 2015, 2016, 2018). A few works have been also performed in transitional areas (e.g. Fatela et al., 2007; Martins et al., 2010, 2013, 2015 a, 2016 b; Moreno et al., 2014; Camacho et al., 2015; Laut et al., 2016).

Diversity of benthic foraminifera in the Portuguese continental margin is not yet entirely known and the pattern of occurrence and ecology of many species is also yet poorly understood. Knowledge about biodiversity and species ecology are fundamental for paleoenvironmental and palaeoceanographic reconstructions. Thus, this work intends to contribute to the definition of a database of the species living in the central region of Portugal, including the Aveiro Lagoon, commonly known as the Ria de Aveiro, and in the adjacent continental shelf. It also intends to analyses the distribution patterns as a function of depth, from transitional regions to the outer continental shelf (a macroscale pattern) of foraminifera found in living and total assemblages (living + dead) of benthic foraminifera and to present updated taxonomic data and illustrations of most of the species found in this region.
RESEARCH PAPER

\section{Study Area}

The study area (Fig. $1 \mathrm{~A}$ ) is located in the central region of Portugal between Espinho (at north) and Cape Mondego (at south). In this sector, the continental shelf, with a width that varies between $38 \mathrm{~km}$ near the Aveiro Canyon (Fig. $1 \mathrm{~B}$, C) and $60 \mathrm{~km}$ in front of Cape Mondego, has a smooth flat surface. It is gently inclined to the west, with the very spaced bathymetries arranged mostly parallel to the coastline. Off Furadouro, the flat continental shelf is interrupted by the outcrop of Cretaceous carbonate formations (Pontal da Galega and Pontal da Cartola) and by the Morraceiros relief in front of Mira (Fig. 1 B, C), formed by Mesozoic and Cenozoic carbonate rocks (Vanney and Mougenot, 1981).

Climatologically the study area is located at the northern part of the northern-hemisphere subtropical high-pressure belt and its climate depends on the Azores anticyclone location (Lopes et al., 2009), at the northernmost limit of the Eastern North Atlantic Upwelling System (Peliz et al., 2002).

The currents system presents a strong seasonal variability by presenting an upwelling season (from May to September) associated with prevailing north winds and a winter regime characterized by the weakening of north winds and the occurrence of storms under the influence of south and southwest winds (Vitorino et al., 2002 a, b).

The Aveiro Canyon, with its headrest installed in Upper Cretaceous and Tertiary formations and the ESSE-WNW direction development, is located at about $30 \mathrm{~km}$ from the coastline and below $110 \mathrm{~m}$ depth. This submarine valley, has a wide U-shaped open (Pereira, 1992). It describes, in its upper section, a semicircle with about $10 \mathrm{~km}$ in diameter and drains into the Iberian Abyssal Plain (Vanney et al., 1979). The slope break, at the average depth of $160 \mathrm{~m}$ and more than $50 \mathrm{~km}$ from the coast, marks the edge of the continental shelf and the transition to the continental slope. The continental slope with average slopes of $1 \%$, extends up to $3000 \mathrm{~m}$ depth.

The surface sediments of the studied area are dominated by sand (Dias and Nittrouer, 1984, Dias, 1987; Abrantes et al., 1994; Magalhães, 1999). Other classes such as clay silt, sand-silt-clay and silt sand occur, but occasionally, depending on the rock outcroppings of the middle and outer or upper continental slopes. The sand is predominantly terrigenous and quartzous in the inner and middle shelf, whereas the biogenic component, mainly composed by foraminifera and mollusks shells, dominates in the outer continental shelf, the shelf break and upper continental slope (Dias and Nittrouer, 1984; Dias, 1987; Abrantes et al., 1994). The temperatures of the Aveiro coastal waters vary between $10^{\circ} \mathrm{C}$ in January and $20^{\circ} \mathrm{C}$ in September, whereas the mean salinity varies between 34.5 and 35.3 (Moita, 2001; Peliz et al., 2002). 


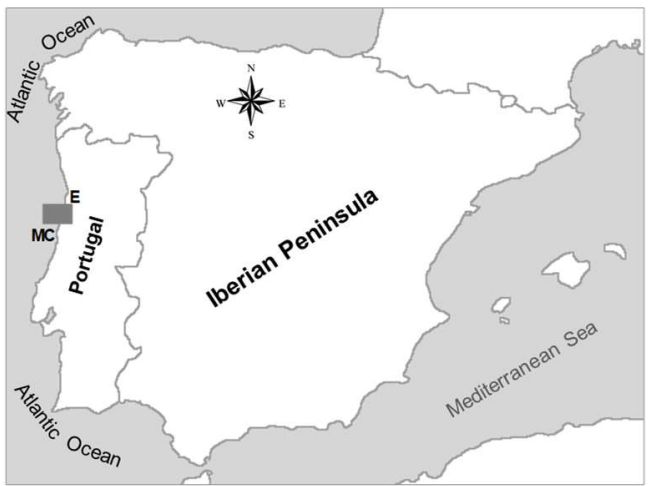

A

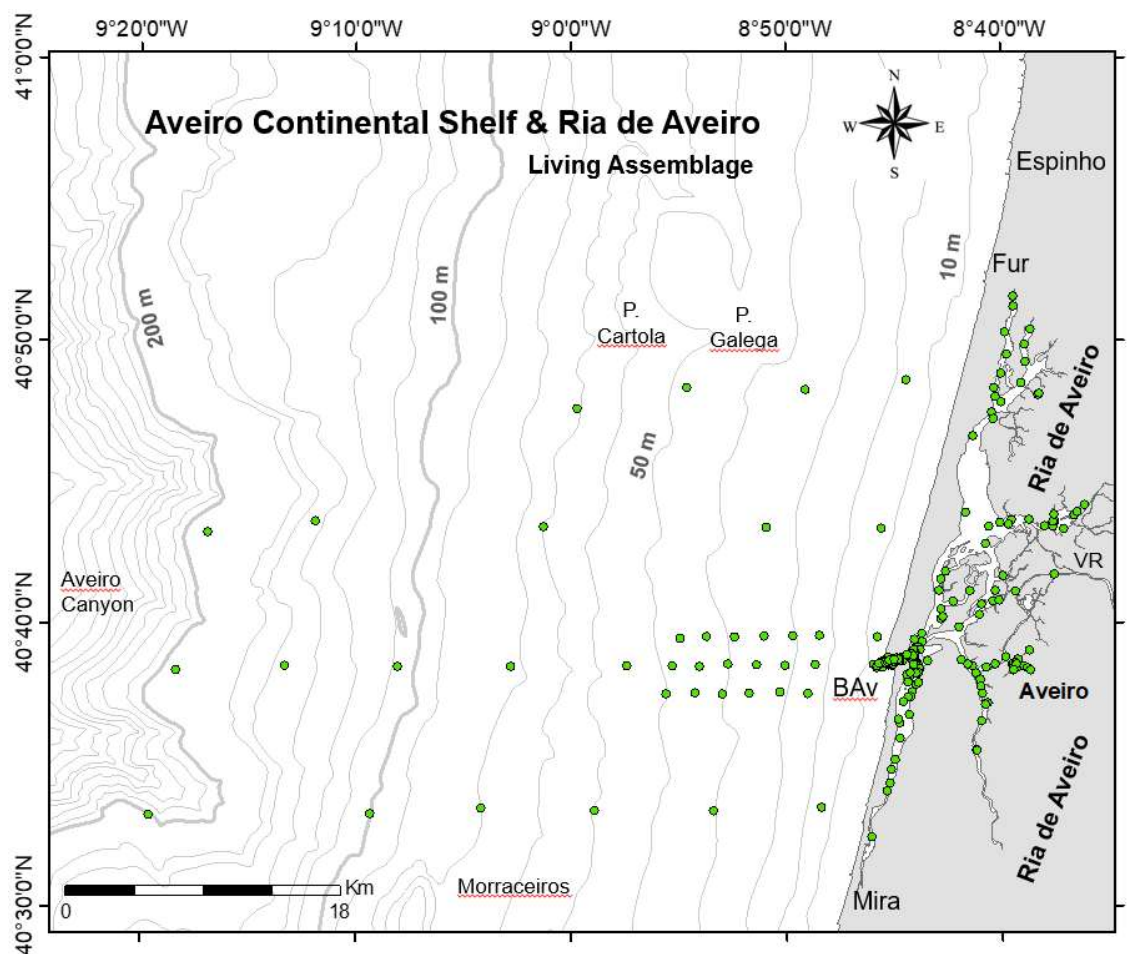

$\mathrm{B}$

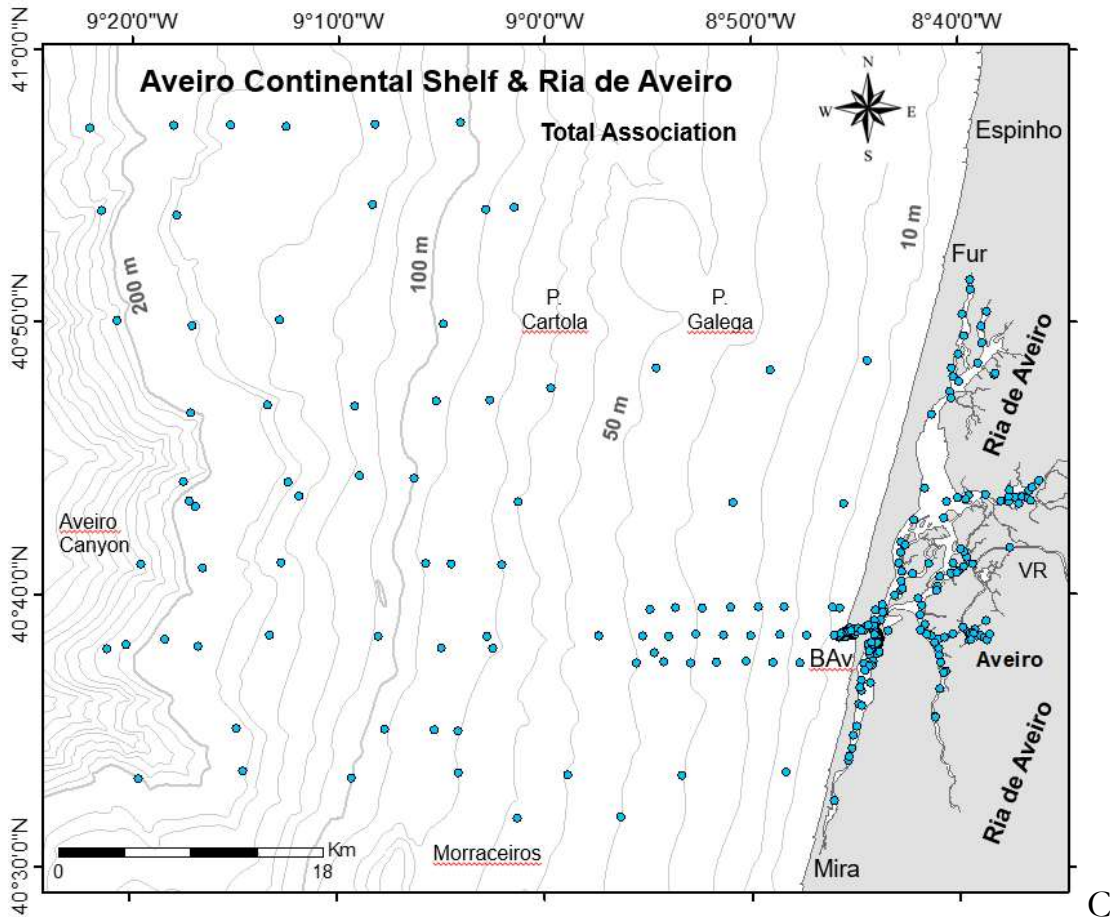

Fig. 1. A. Study area in Aveiro Continental Shelf and Ria de Aveiro (marked with a gray square). B. Sampling analyzed for living foraminiferal assemblages. C. Sampling analyzed for total foraminiferal (living + dead) assemblages. Legend: E - Espinho; MC - Cape Mondego; P. Cartola - Pontal da Cartola; P. Galega - Pontal da Galega; Fur - Furadouro; VR - Vouga River; BAv - Barra de Aveiro. Bathymetry with $10 \mathrm{~m}$ contour intervals.

During summer, the coastal water temperature, due to the occurrence of upwelling events, may decrease about $2^{\circ} \mathrm{C}$ relatively to the offshore temperature. From April to October, the upwelling system induces the increase of nutrients and phytoplankton biomass accumulation (Moita,
2001; Lopes et al., 2009). The coast adjacent to the study area, with rectilinear and NNE-SSW orientation, is interrupted by the Aveiro Lagoon mouth with an artificial inlet of $1.3 \mathrm{~km}$ long, $350 \mathrm{~m}$ wide and $20 \mathrm{~m}$ wide, commonly known as the Barra de Aveiro. This lagoon is located 
between the parallels $40^{\circ} 52^{\prime} \mathrm{N}$ and $40^{\circ} 30^{\prime} \mathrm{N}$ and can be considered as an enclosed by sandbars estuary, according to the classification of Pritchard (1967, 1989), or a partially closed lagoon, according to Nichols and Allen (1981). Currently, the lagoon, with a surface area of about $250 \mathrm{~km}^{2}$ (Dias, 2001), presents $8.5 \mathrm{~km}$ of maximum width and $45 \mathrm{~km}$ of length (Dias et al., 2000; Dias 2001). Its average depth is about $1 \mathrm{~m}$, except in the navigation channels, where the depth is maintained between 4 and $7 \mathrm{~m}$ by dredging. At the lagoon mouth depths reach about $30 \mathrm{~m}$.

The main factors that affect the salinity of the Ria de Aveiro are the oceanic water and freshwater flows. The lagoon receives the contribution of several rivers and streams like the Vouga, Antuã and Boco river flows (Dias et al., 1999; Dias, 2001). Salinity increases during the flood, by reaching the highest values at high tide, when the marine water occupies the entire central zone of the lagoon. In periods of ebb, salinity decreases because oceanic water is drained out from the system and replaced by brackish water coming from the inner sectors of the channels. Salinity near the lagoon mouth has an average value of 32 , while in the inner sectors it decreases to about 0.5 (Borrego et al., 1990).

The anthropic activity, in Aveiro Lagoon initiated mainly with the artificial opening, the construction of the jetties and the engineering works to access the port. The intense industrial and agricultural activity around of the lagoon are being also affected this ecosystem (Martins et al., 2010, 2013, 2015 a, 2016 b).

\section{Materials and Methods}

This work analyzes the distribution and occurrence of living and total (living plus dead) benthic foraminifers in the Aveiro Lagoon and in the adjacent continental shelf (center of Portugal), as a function of depth and latitudinal changes. It also provides a check list of most of the species found in this region both in living and total (living plus dead) assemblages and updated taxonomic data and illustrations of the most common species. It includes a compilation of data obtained in 334 surface sediment samples by: Martins et al. (2010, 2013, 2015 b, 2016b) for living foraminiferal assemblages in Aveiro Lagoon; Martins et al. (2014, 2016 b) for the dead associations in Aveiro Lagoon and; Martins et al. (2012) for total assemblages in Aveiro continental shelf and upper slope and; Martins et al. (2017, 2019) for the living and dead assemblages in Aveiro continental shelf.

The study area is located, at south of Espinho and north of Mondego Cape, in depths <700m (Fig. 1). Appendices 1 and 2 include the samples location (latitude, longitude and depth). Details of the applied methodology for sampling and data acquisition is described in the above-mentioned works.

The living assemblage was based on Rose-Bengal stained colored specimens. All living (stained) and total (living plus dead) foraminiferal specimens were picked out from the same sample split, identified, and counted under stereoscopic microscopic at $80-200 \mathrm{X}$ magnification. A sufficient amount of sample was used to find at least 300 specimens. Samples with reduced number of organisms ( $<100$ specimens) were listed for living assemblages but were not considered in the statistical analysis. The taxonomic classification followed the World Foraminifera Database, Worms (Hayward et al., 2018), which considers the genetic evolution of foraminifera and so produces a natural hierarchical classification. Most of the identified foraminiferal species were imaged with a digital Scanning Electron Microscope EVO MA10 (Zeiss). The plates organization also followed the Worms Database (Hayward et al., 2018).

This work also presents systematic data of the most common species. Descriptions, synonymies and ecological information were presented for agglutinated species typical of coastal areas whose ecology and distribution are almost unknown. Species descriptions were in general based on the original description, accessed on Ellis and Messina (19422008) and other cited literature.

For statistical analysis, only the species with relative abundance $>5 \%$ were considered. After arcsine-root transformation, the data were analyzed by Correspondence Analysis (CA) and Principal Components Analysis (PCA). The PCA was performed to explain the variance of the main species, taxa/groups of species in living and total assemblages in relation to stations depth. The maps of

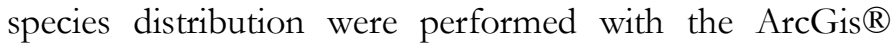
software 10.2 using WGS84 projection and Universal Transverse Mercator (UTM) zone $29 \mathrm{~N}$ coordinates.

\section{Results}

In the analyzed samples, 390 (Appendix 1) and 211 (Appendix 2) species of benthic foraminifera were identified in total (TA) and in the living assemblages (LA), respectively. The comparison between the maximum percentages of each species in LA and TA is presented in Appendix 3. The Appendix 4 lists the taxonomy of identified species based on the World Foraminifera Database, Worms (Hayward et al., 2018). The same appendix also lists the plates and photos (see Plates 1-19) of the most common species. The species are presented in alphabetical order with their original name in Appendix 5.

Fifty species reached $\geq 10 \%$ in total assemblages (TA) and/or living assemblages (LA) in the Ria de Aveiro and at the nearby marine coastal area. The distributional maps of 18 species that reached relative abundance $>30 \%$ (and lowest percentage $>3 \%$ ) in both TA and/or LA were included in Fig. 2. 
RESEARCH PAPER
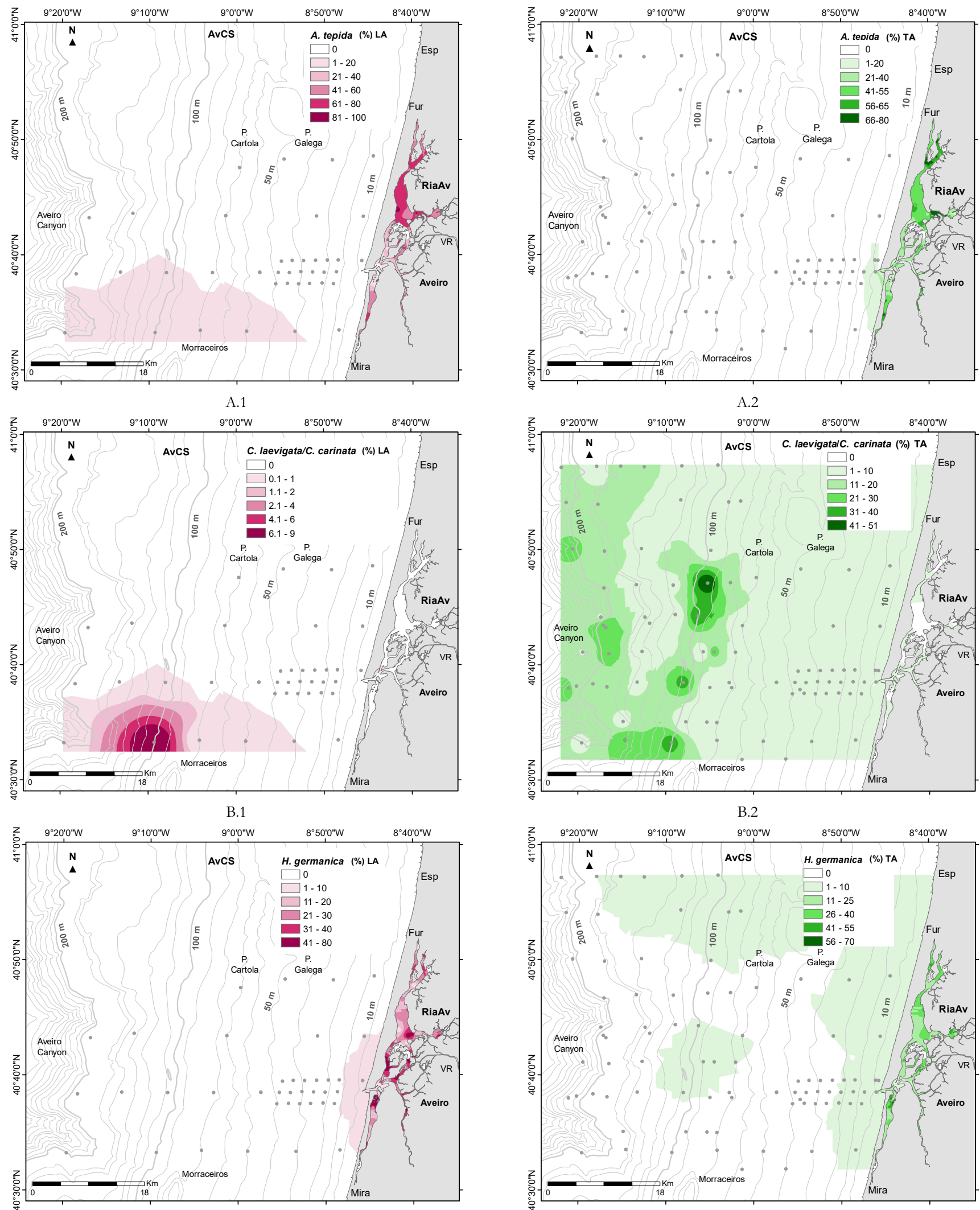

C.1

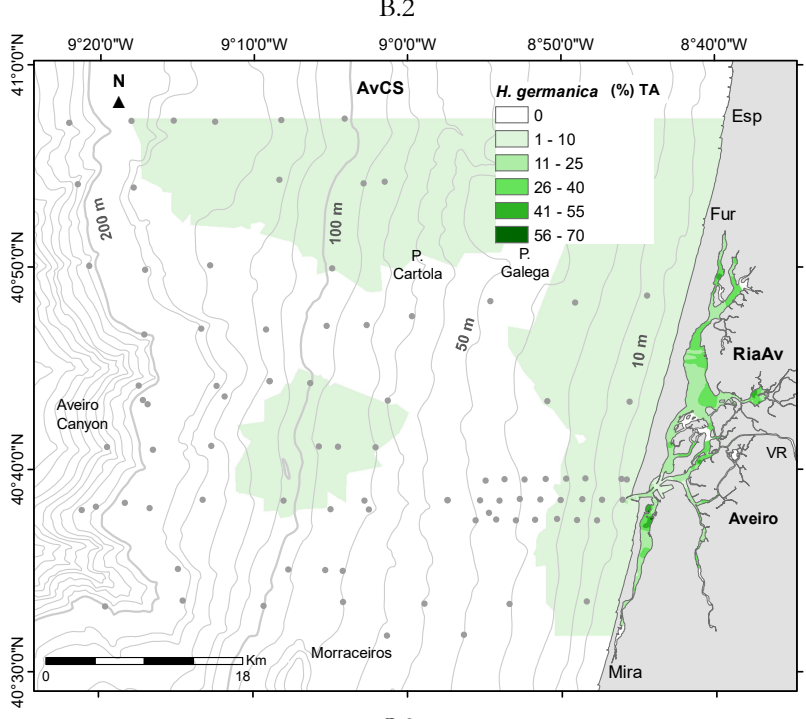

C.2

Fig. 2. Maps of distribution of 1. total associations (TA) and 2. living assemblages (LA) of: A. Ammonia tepida; B. Cassidulina laevigata/Cassidulina carinata; C. Haynesina germanica. 
RESEARCH PAPER
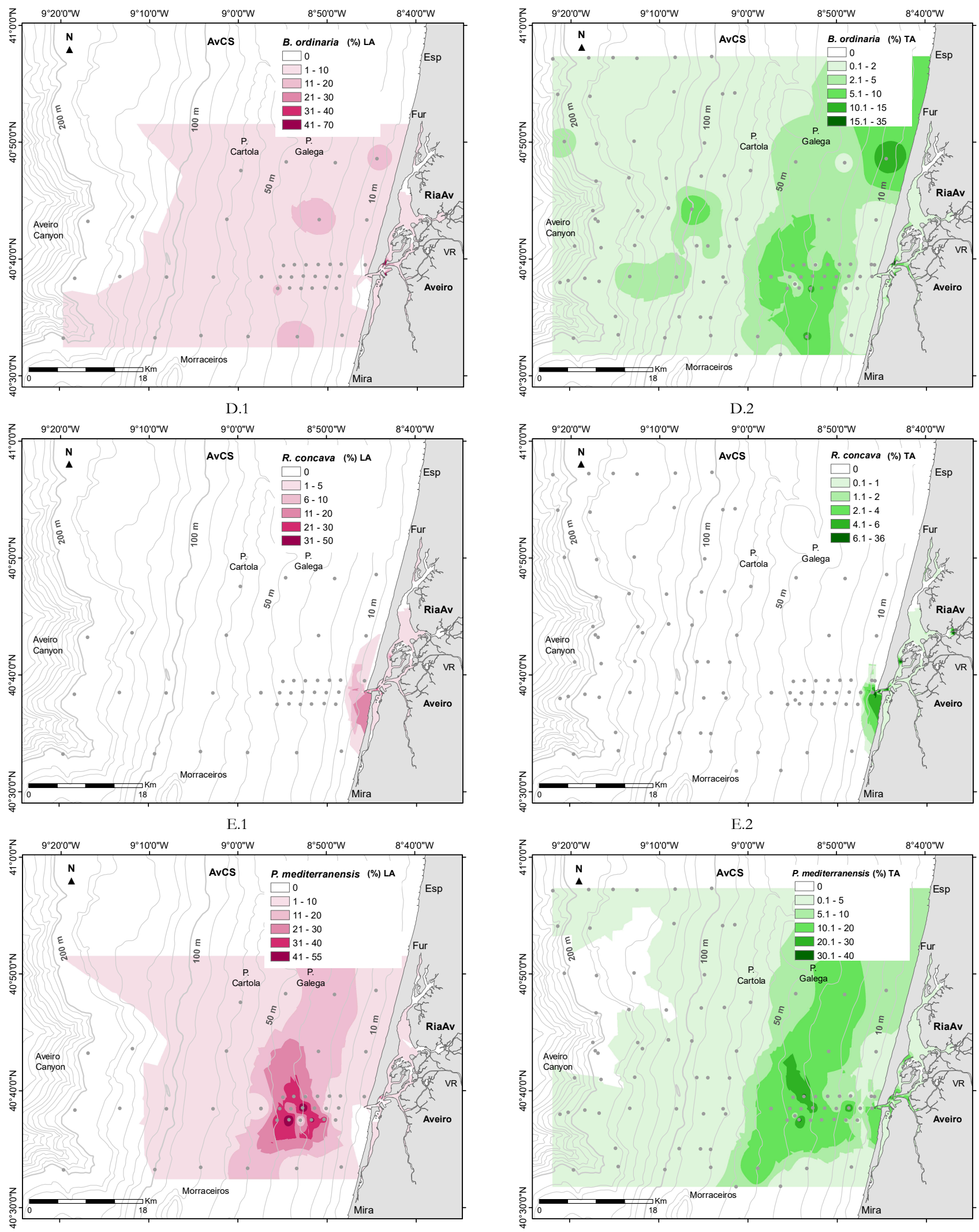

F.1

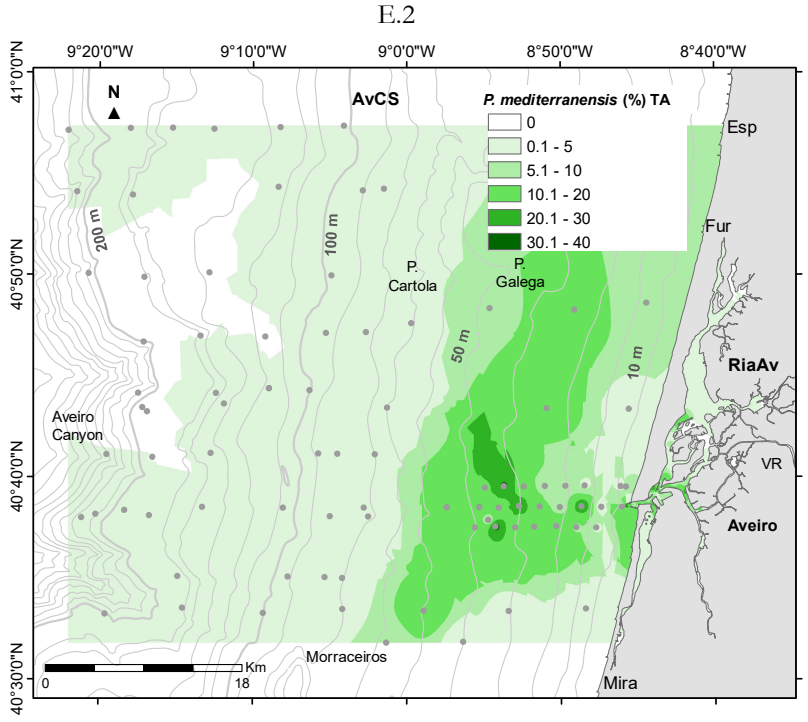

F.2

Fig. 2. (cont.). Maps of distribution of 1. total associations (TA) and 2. living assemblages (LA) of: D. Bolivina ordinaria; E. Rotaliammina concava; F. Planorbulina mediterranensis. 
Journal of Sedimentary Environments

Alves Martins et al.

Published by Universidade do Estado do Rio de Janeiro

4 (1): 1-52. January-March, 2019

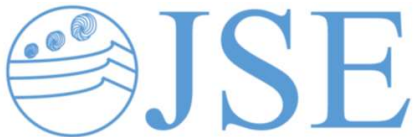

doi: $10.12957 /$ jse. 2019.39308

RESEARCH PAPER
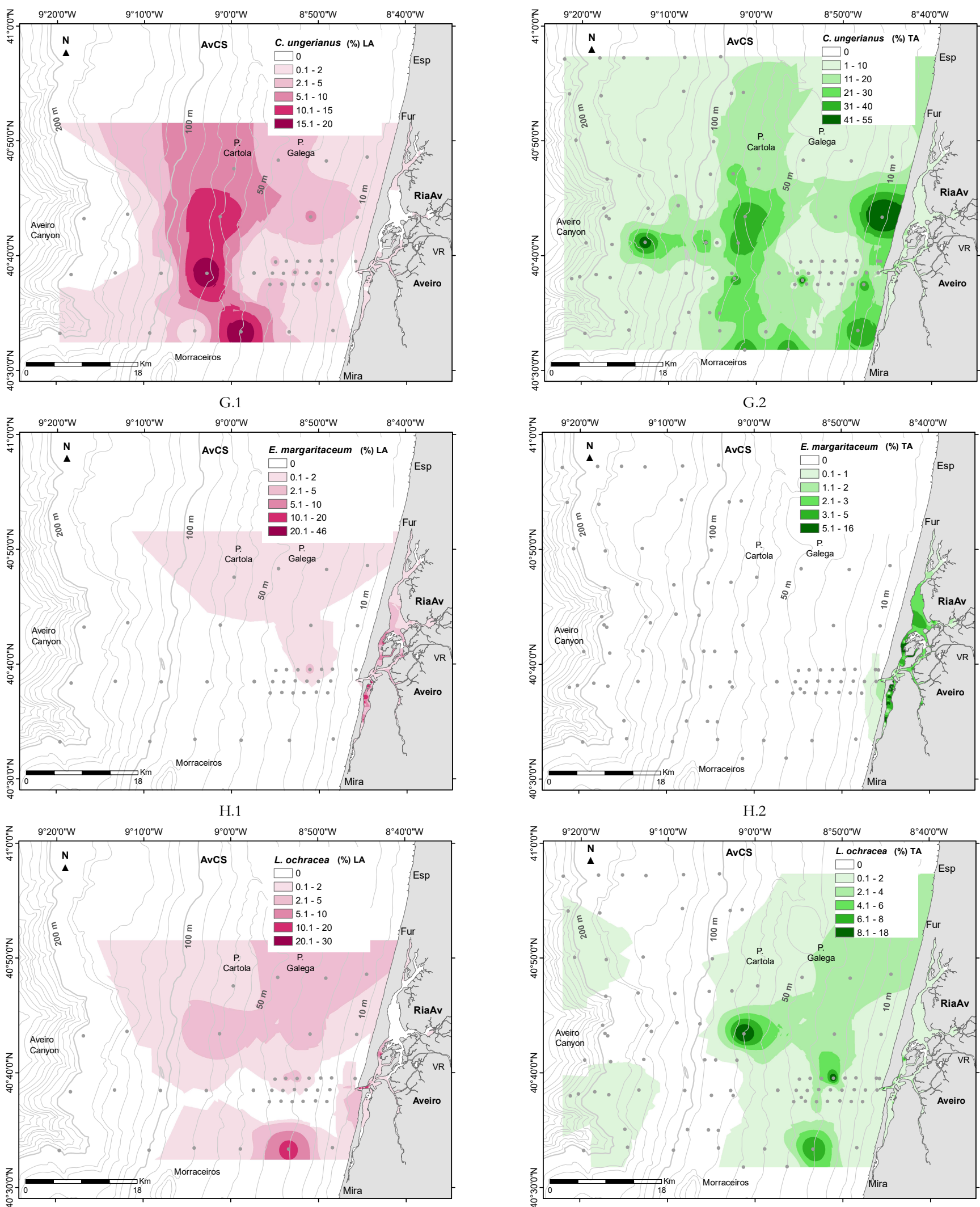

I.1

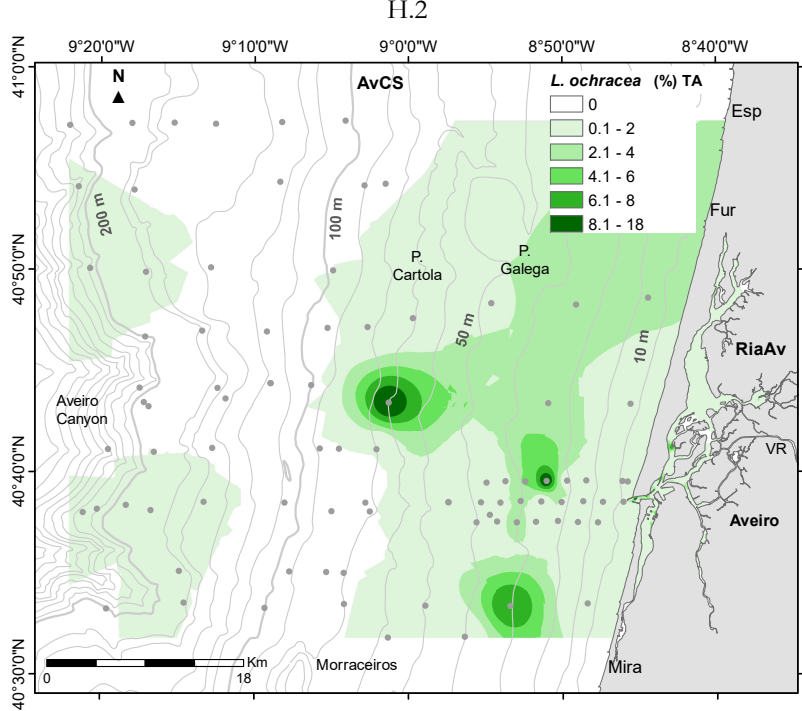

I. 2

Fig. 2. (cont.). Maps of distribution of 1. total associations (TA) and 2. living assemblages (LA) of: G. Cibicidoides ungerianus; H. Elphidium margaritaceum; I. Lepidodenterammina ochracea; 
Journal of Sedimentary Environments

Alves Martins et al.

Published by Universidade do Estado do Rio de Janeiro

4 (1): 1-52. January-March, 2019

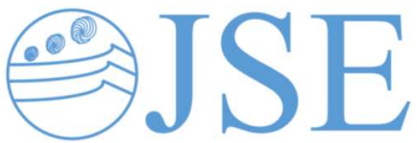

doi: $10.12957 /$ ise 2019.39308

RESEARCH PAPER
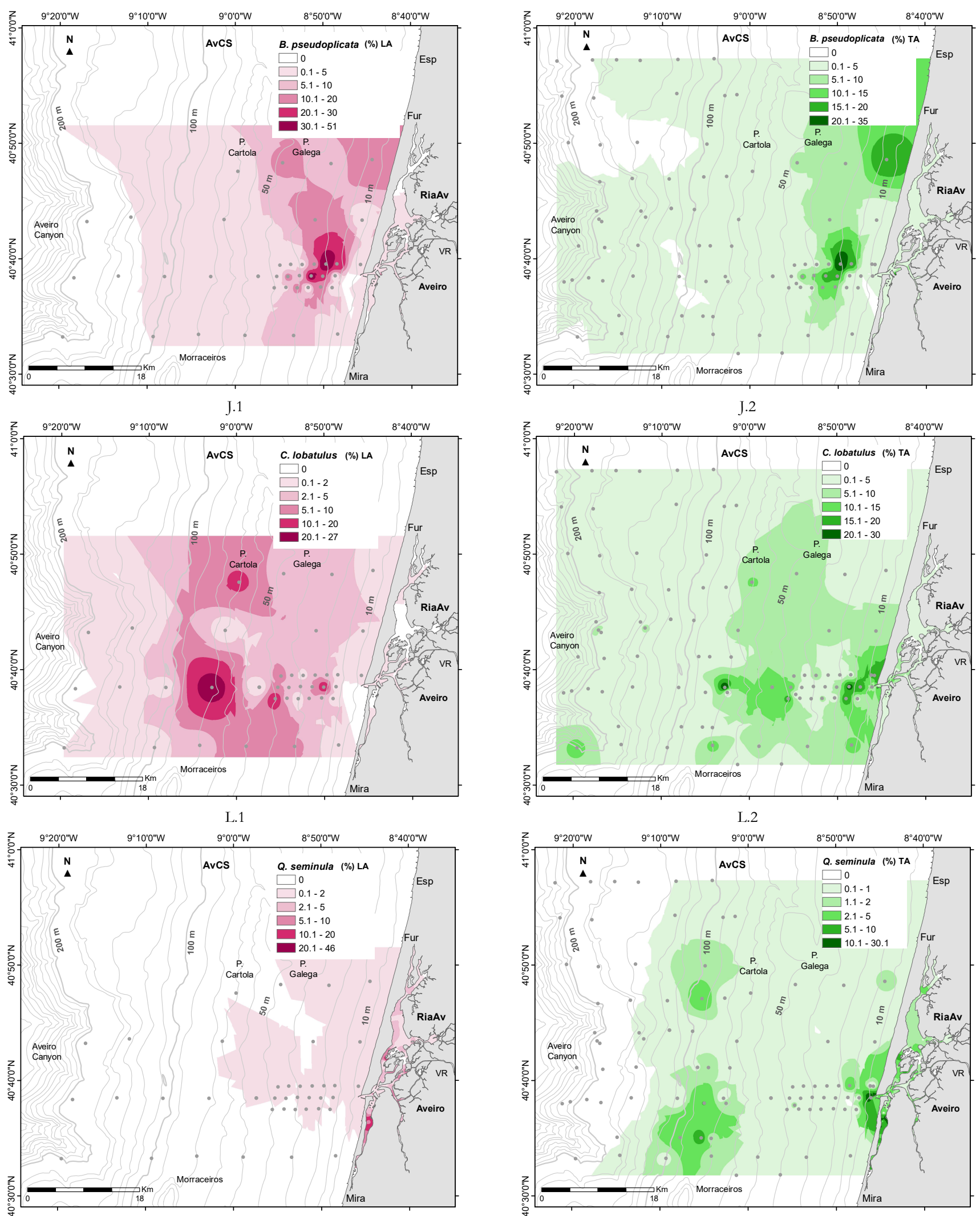

M.1

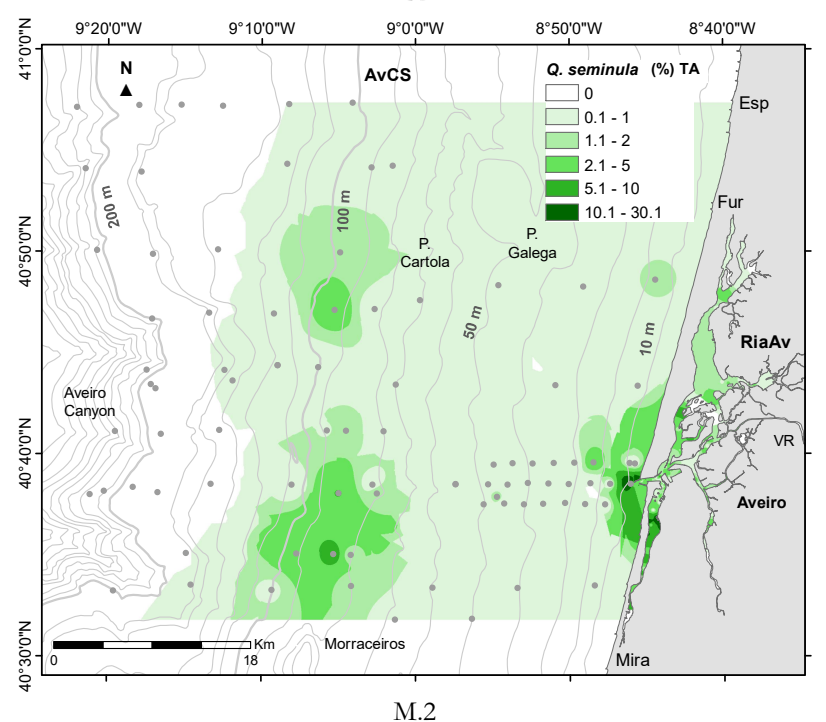

Fig. 2. (cont.). Maps of distribution of 1. total associations (TA) and 2. living assemblages (LA) of: J. Bolivina pseudoplicata; L. Cibicidoides lobatulus; M. Quinqueloculina seminula. 
RESEARCH PAPER
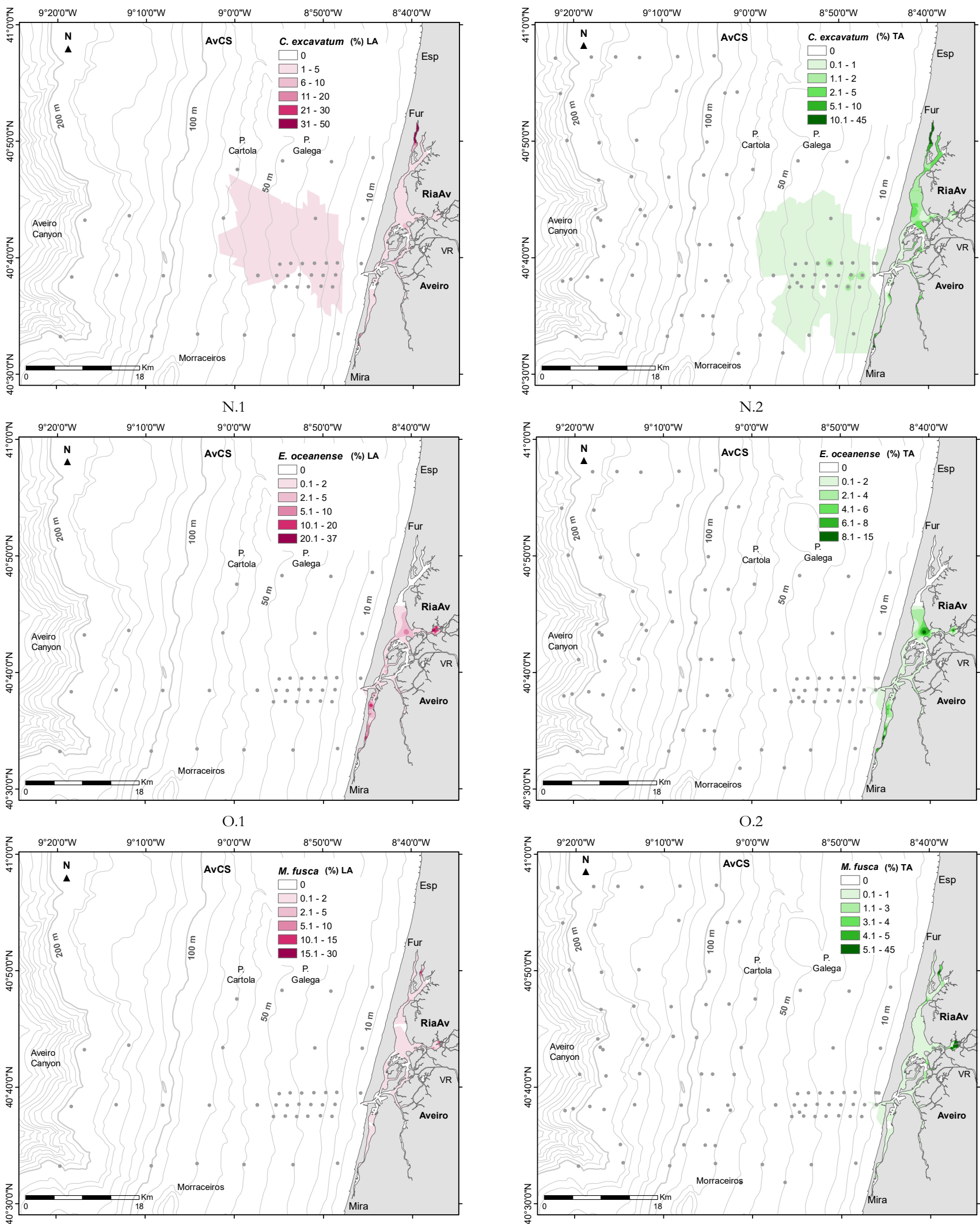

P.1

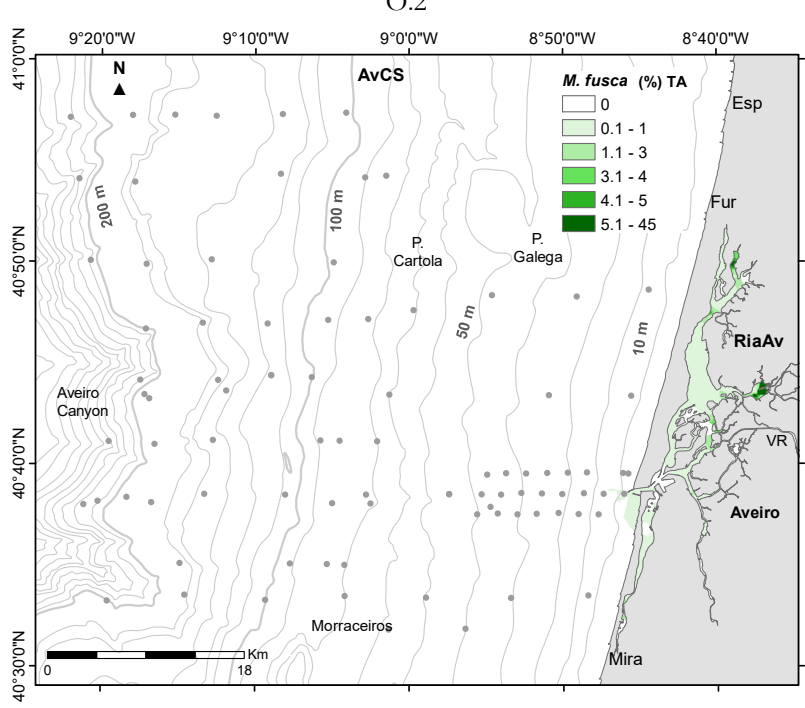

P.2

Fig. 2. (cont.). Maps of distribution of 1. total associations (TA) and 2. living assemblages (LA) of: N. Cribroelphidium excavatum; O. Elphidium oceanense; P. Miliammina fusca. 
RESEARCH PAPER
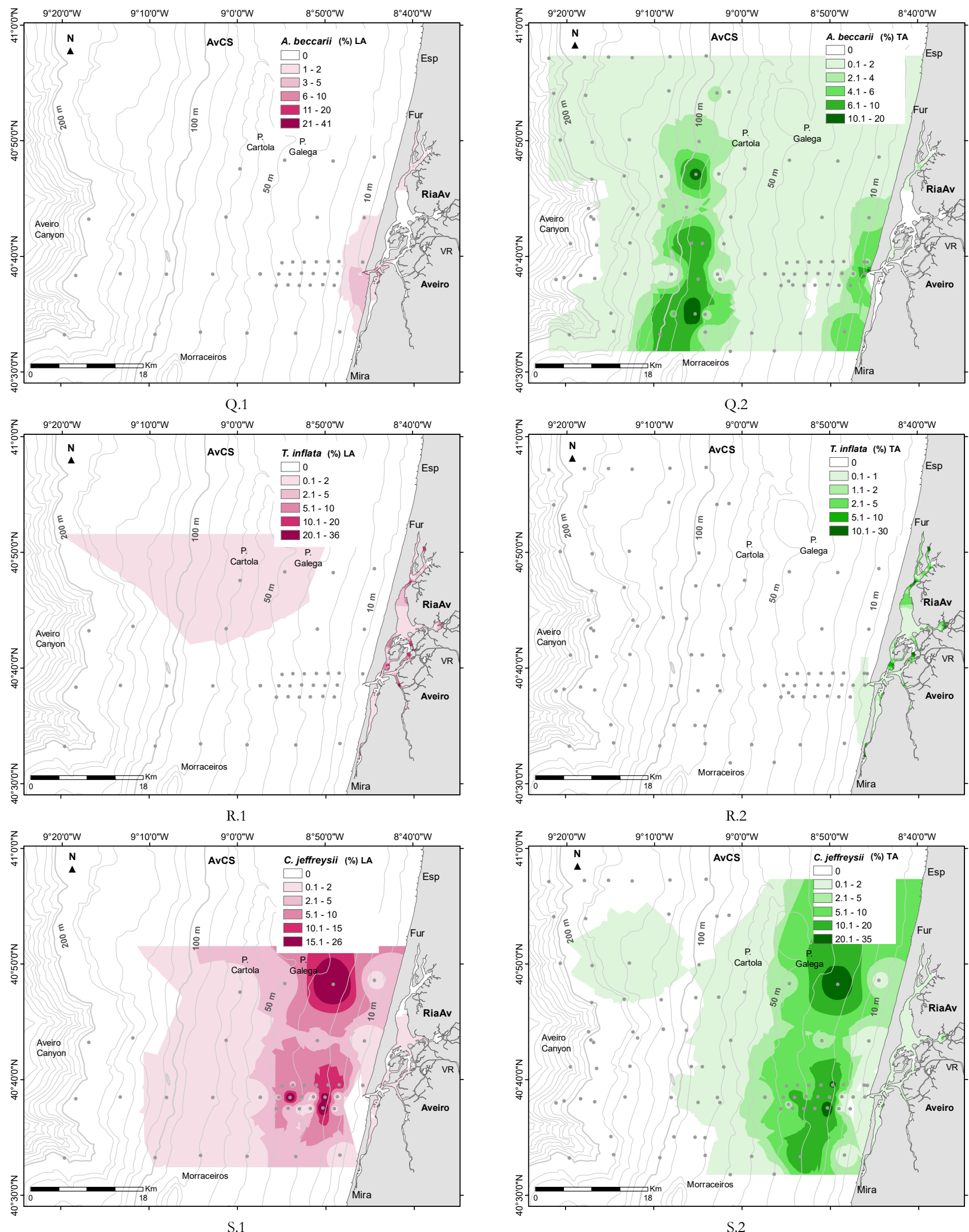

Fig. 2. (cont.). Maps of distribution of 1. total associations (TA) and 2. living assemblages (LA) of: Q. Ammonia beccarï; R. Trochammina inflata; S. Cribrostomoides jeffreysii. 
Statistical results are presented in Appendix 6 for LA and in Appendix 7 for TA. Results of CA and PCA scores, component $1 \mathrm{vs}$. component 2, of the analyzed samples for LA and TA of benthic foraminifera are presented in Fig. 3 and Fig. 4, respectively.

The results of the PCA scores both for LA and TA suggest a relationship of most of the samples/sites with depth. The correlation of the PCA score of axis 1 with depth is higher in TA (0.57; Appendix 7) than for LA (0.41; Appendix 6). The other PCA axes are low correlated with depth. The CA results of living foraminifera (Fig. 3A) better shows the depth trend compared to PCA (Fig. 3B), where this trend is marked in a combination of the two first principal components (the diagonal).

The plot of the PCA loadings based on the percentage of living and total benthic foraminiferal species (with relative abundance $>5 \%$ ), in function of depth is presented in Figures 4-5, respectively. The PCA loadings for LA and TA suggests that some species are mainly related to low depths, such as: Ammonia tepida, Haynesina germanica, Entria macrescens, Trochammina inflata, Cribroelphidium excavatum, Quinqueloculina seminula, Miliammina fusca, Elphidium margaritaceum, Cribroelphidium williamsoni, Elphidium oceanense, Ammonia parkinsoniana, Haplophragmoides manilaensis, Trochamminita irregularis and Trochamminita salsa, whereas species such as Bolivina spathulata/B. catanensis, Bulimina elongata/B. gibba, Cibicidoides ungerianus, Globocassidulina crassa, Gyroidina umbonata, Hanzawaia nitidula and Cassidulina laevigata/C. carinata increases their relative abundance with depth.

The PCA loadings for LA (Fig. 5) indicates that Bolivina ordinaria, Bolivina pseudoplicata, Cibicidoides lobatulus, Cribrostomoides jeffreysii, Gavelinopsis praegeri, Globocassidulina minuta, Lepidodeuterammina ochracea, Nodulina dentaliniformis, Nonionella stella, Paratrochammina haynesi, Paratrochammina bartrami, Planorbulina mediterranensis, Rotaliammina concava and Rotorbis auberii also tend to be related with increasing depth, but the PCA loadings for TA, showed an opposed tendency (Fig. 6).

The PCA loadings for LA (Fig. 5) also show that Bolivina variabilis, Cribroelphidium gerthi, Discorbinella bertheloti, Elphidium complanatum, Glomospira gordialis, Portatrochammina murrayi, Quinqueloculina lata, Remaneica anglica, Remaneica belgolandica, Remaneicella gonzalezi, Rotaliammina adaperta, Spirillina vivipara, Trochammina squamata and Valvulineria araucana also tend to rise their relative abundance with depth.

The PCA loadings for TA provide indications of additional species (Fig. 6). It showed for instance that Ammoscalaria psendospiralis, Arenoparrella mexicana, Asterotrochammina aspera, Aubignyna perlucida, Discorbis parkeri, Globocassidulina crassa rossensis, Lepidodeuterammina celtica, Pileolina patelliformis, Rotaliammina sigmoidea, Scherochorella moniliformis and Tiphotrocha comprimata tend to be more represented in the shallower stations of the study area, whereas Bolivina compacta, Bolivina difformis, Bolivina dilatata, Bolivina striatula, Bolivinella seminuda, Bolivinita quadrilatera,
RESEARCH PAPER

Bulimina marginata, Bulimina truncana, Buliminella tenuata, Cancris oblongus, Chilostomella ovoidea, Cibicidoides pachyderma, Cibicidoides pseudoungeriana, Elphidium crispum, Nonion fabum, Nuttallides umbonifera, Pullenia bulloides, Sigmoilopsis schlumbergeri, Textularia sagittula, Trifarina angulosa and Uvigerina peregrina are more represented in deeper stations of the study area.

\subsection{Taxonomy of some selected Lituolida (Trochamminidae and Remaneicidae) species}

Due to the large number of species found in the study area only some Lituolida (Trochamminidae and Remaneicidae) species, whose pattern of distribution and ecology is worse recognized in the region, are described below.

\section{Genus Asterotrochammina Bermúdez and Seiglie, 1963}

Asterotrochammina aspera Brönnimann and Zaninetti, 1984

$$
\text { (Plate 3, Figs. 6) }
$$

Morphological description: Test is a very compressed right coiled trochospiral; the spiral side is low convex and the umbilical slightly concave. The umbilicus is open and show the central portion of the preceding chambers. The test is composed by about 22 chambers and has a diameter of about $220 \mu \mathrm{m}$. The chambers of the last two whorls at the spiral side are retroverse. The test has a subcircular, slightly lobulated outline contour. Each chamber has two openings of Deuterammina-type: the primary is interiomarginal, rounded and has subperipheric border structures; the secondary opening at the end of the innermost lobe is in a sutural position and directed backward. The primary aperture is in contact with the exterior, whereas the secondary apertures communicate with the exterior axially. The wall is rugose, finely granular and brownish.

Ecology and Distribution: It is a common species in the inner to outer continental shelf in South Atlantic Ocean (Disaró, 2014). It was found living (up to 3.5\%) in Aveiro Lagoon and in the nearby inner and mid continental shelf.

\section{Asterotrochammina camposi Brönnimann, 1978}

(Plate 3, Figs. 7-8)

Asterotrochammina camposi Brönnimann, 1978, 3 p.

Morphological description: low trochospiral test; with numerous chambers; interior partially subdivided by infoldings of the umbilical wall that are oriented transverse to the septa. Primary aperture is interiomarginal and extraumbilical. The wall is finely agglutinated.

Ecology and Distribution: Rare. It is rare and was only found in the dead assemblage (up to $1 \%$ ) in the Aveiro middle continental shelf. 


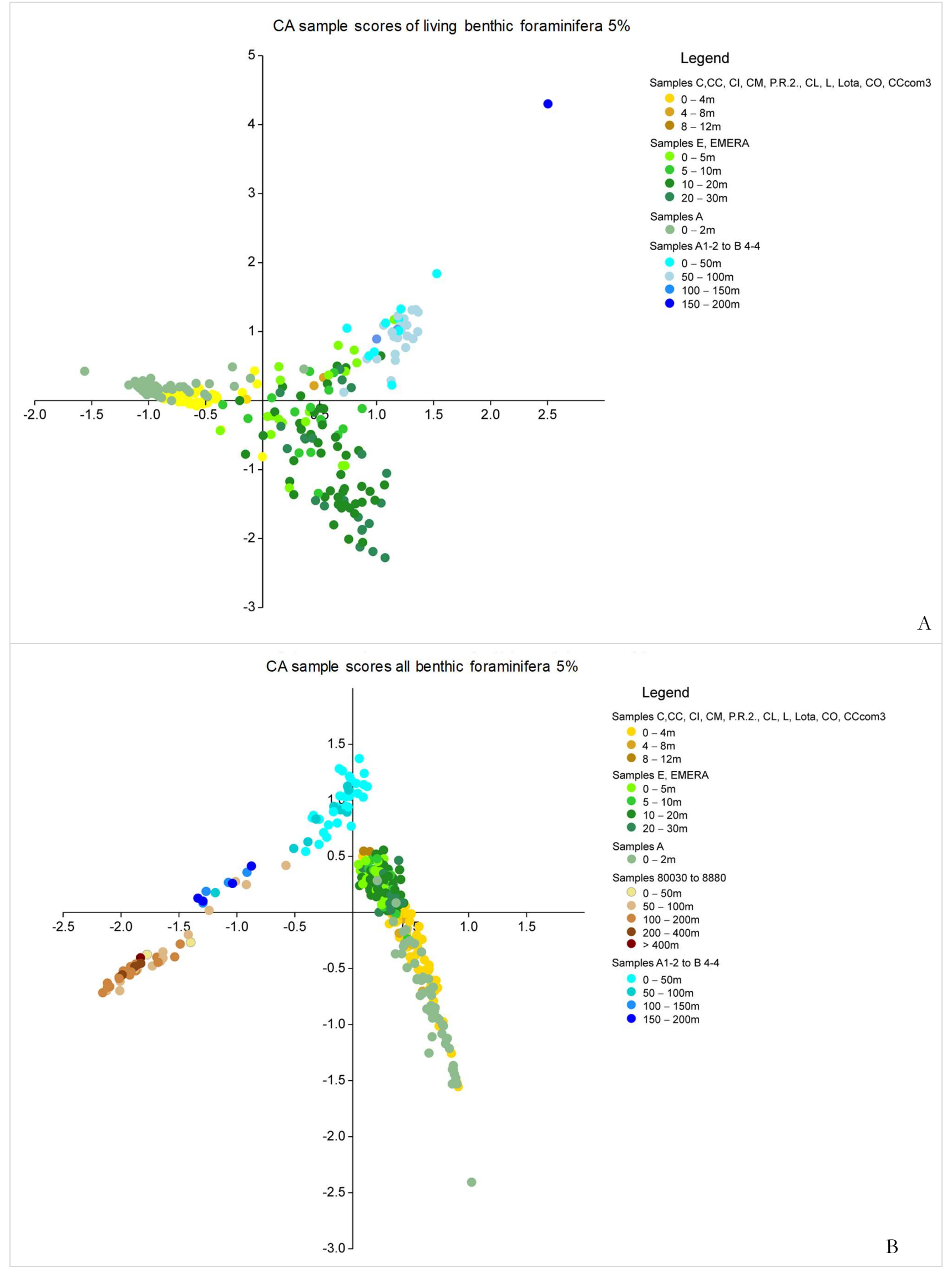

Fig. 3. CA results, component 1 versus component 2, of the analyzed samples for A-LA and B-TA of benthic foraminifera (with relative abundance $>5 \%$ ) in function of depth. 


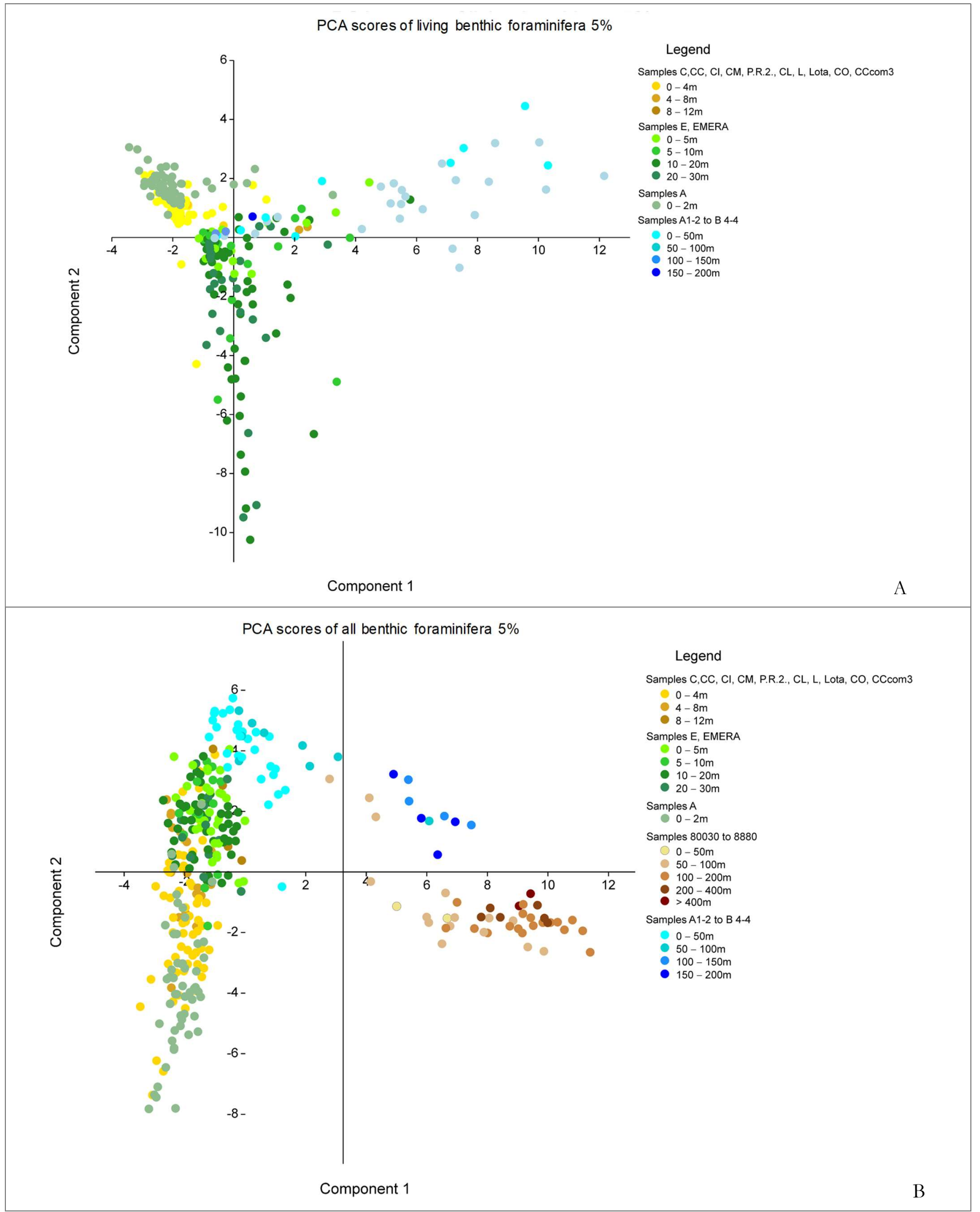

Fig. 4. PCA scores, component 1 versus component 2, of the analyzed samples for A-LA and B-TA of benthic foraminifera (with relative abundance $>5 \%$, in function of depth. 


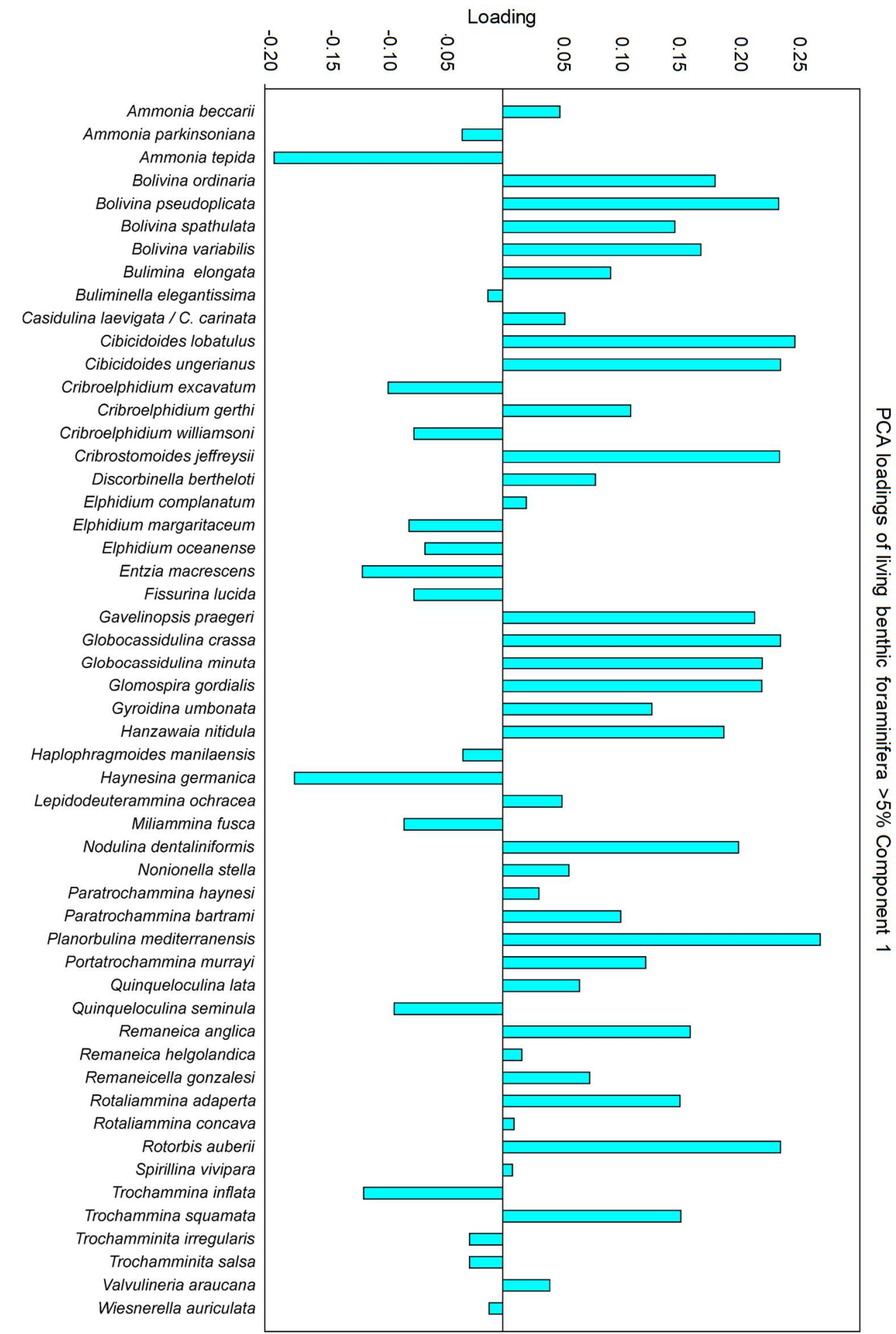

Fig. 5. PCA based on the percentage of living benthic foraminifera species (with relative abundance $>5 \%$ ). Loadings of component 1 characterizing depth. 


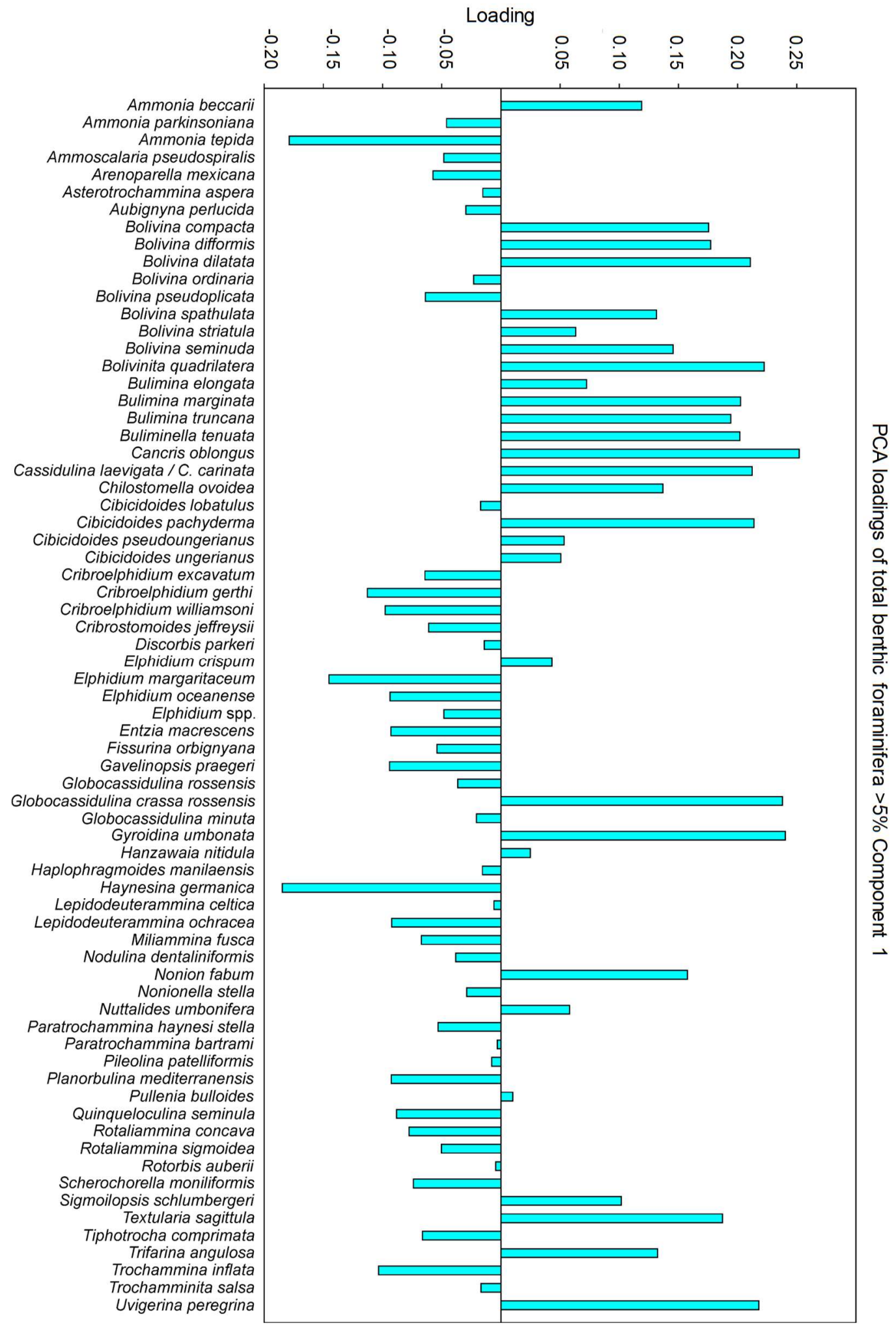

Fig. 5. PCA based on the percentage of total benthic foraminifera species (with relative abundance $>5 \%$ ). Loadings of component 1 characterizing depth. 
Published by Universidade do Estado do Rio de Janeiro

4 (1): 1-52. January-March, 2019

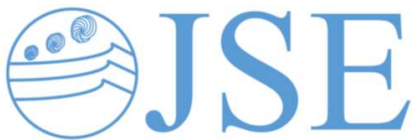

doi: 10.12957 /jse. 2019.39308

RESEARCH PAPER

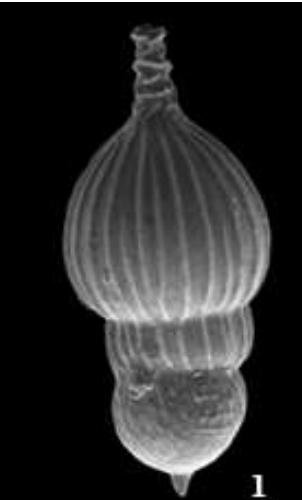

$100 \mu \mathrm{m}$

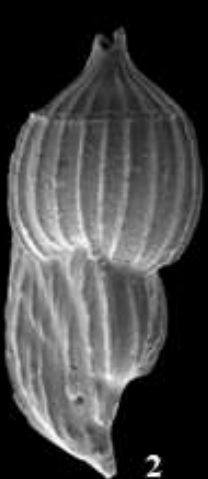

$100 \mu \mathrm{m}$

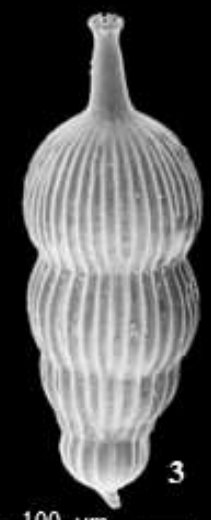

$100 \mu \mathrm{m}$

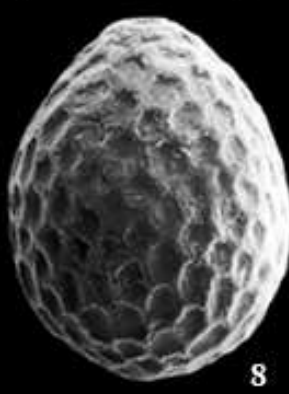

8
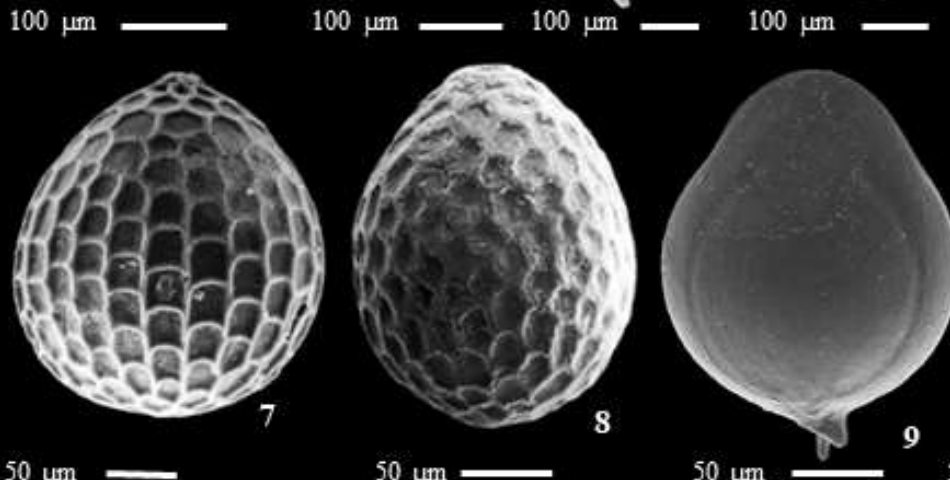

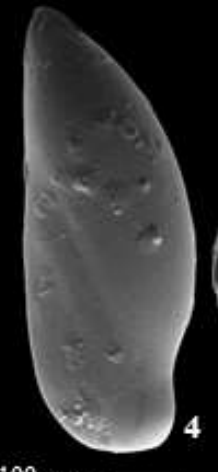

$100 \mu \mathrm{m}$

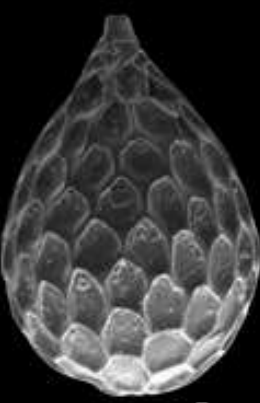

5

$50 \mu \mathrm{m}$

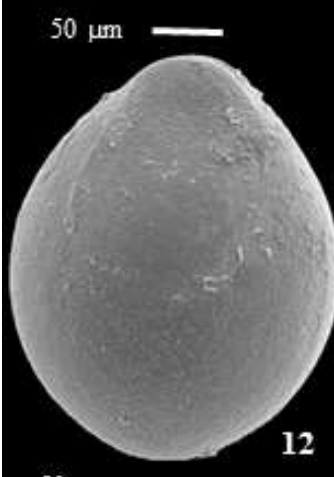

$50 \mathrm{um}$

12
$50 \mu \mathrm{m}$

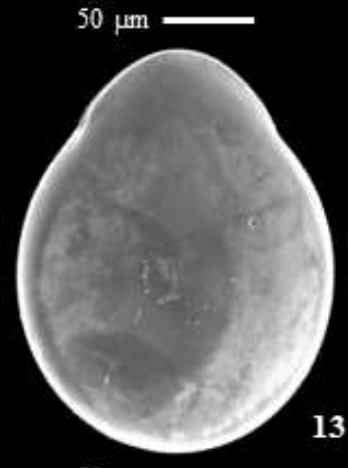

13

$50 \mu \mathrm{m}$ $50 \mu \mathrm{m}$
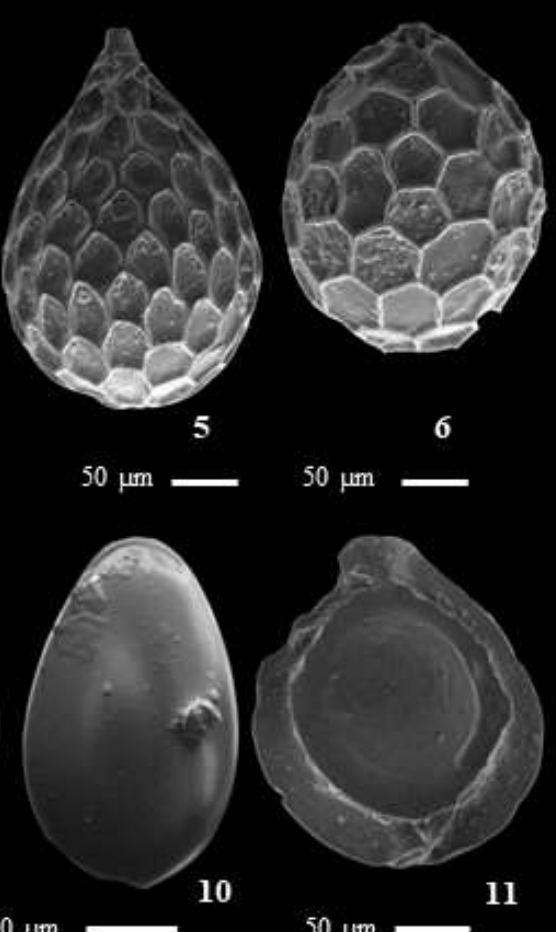

$50 \mu \mathrm{m}$

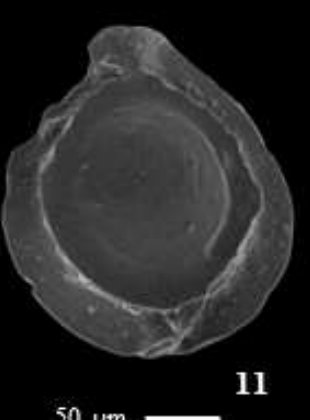

$50 \mu \mathrm{m}$

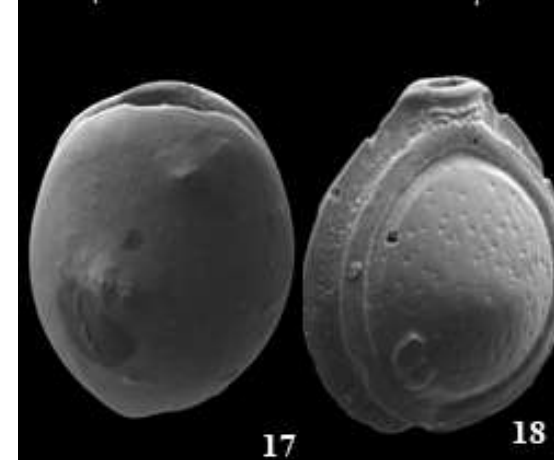

$50 \mu \mathrm{m}$
17

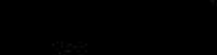

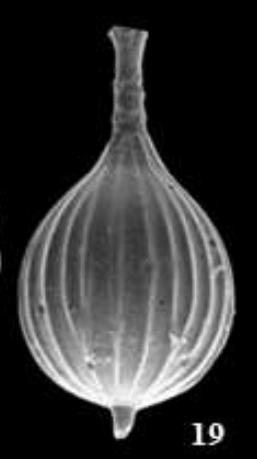

$50 \mu \mathrm{m}$

19

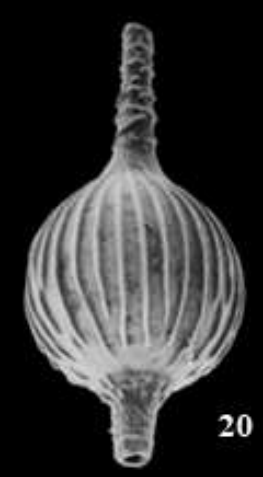

$50 \mu \mathrm{m}$
14

$50 \mu \mathrm{m}$

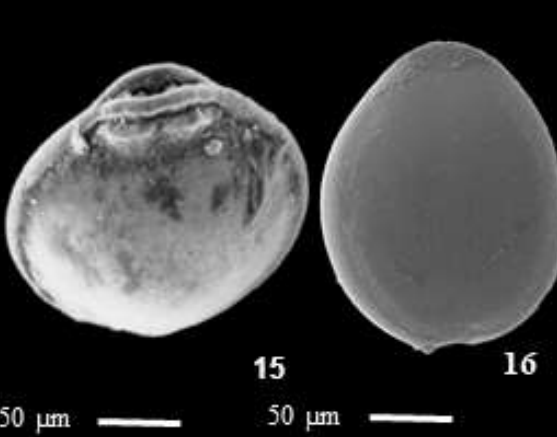

\section{Plate 1}

Plate 1. 1-3. Amphicoryna scalaris (Batsch, 1791); 4. Astacolus crepidulus (Fichtel and Moll, 1798); 5. Conolagena montagui (Silvestri, 1902); 6. Favulina melo (d'Orbigny, 1839); 7. Favulina squamosa (Montagu, 1803); 8. Favulina squamosa (Montagu, 1803); 9. Fissurina annectens (Burrows and Holland, 1895); 10. Fissurina globosocaudata Albani and Yassini, 1989; 11. Fissurina imporcata McCulloch, 1977; 12. Fissurina laevigata Reuss, 1850; 13. Fissurina lucida (Williamson, 1848); 14-15. Fissurina marginata (Montagu, 1803); 16. Fissurina nudiformis McCulloch, 1977; 17. Fissurina quadrata (Williamson, 1858). 18. Fissurina orbignyana Seguenza, 1862; 19. Lagena striata (d'Orbigny, 1839); 20. Lagena strumosa Reuss, 1858; 21. Lagena sulcata (Walker and Jacob, 1798); 22. Laryngosigma byalascidia Loeblich and Tappan, 1953. 


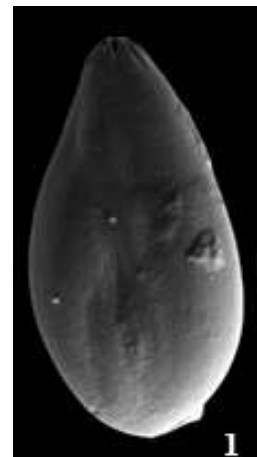

$50 \mu \mathrm{m} \longrightarrow$

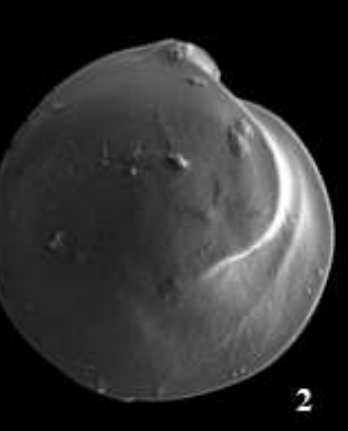

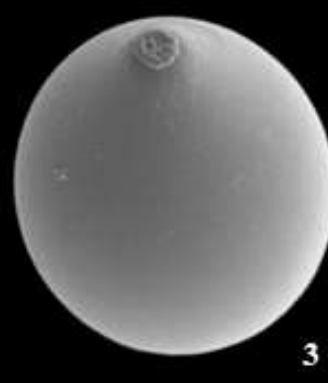

2

$50 \mu \mathrm{m}$

3

$100 \mu \mathrm{m}$

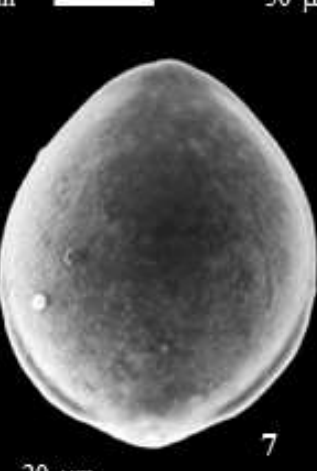

$20 \mu \mathrm{m}$

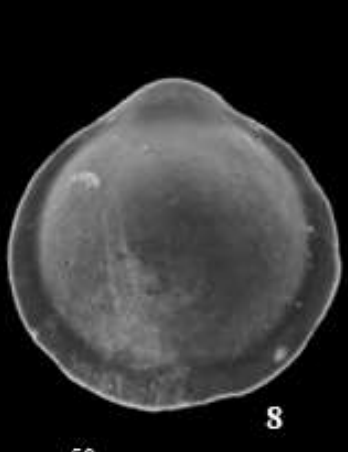

$50 \mu \mathrm{m}$
$100 \mu \mathrm{m}$

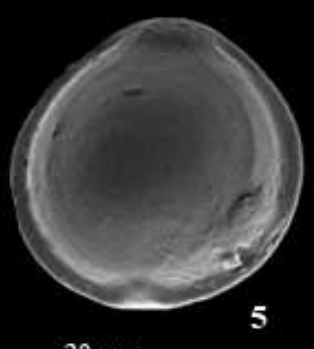

$20 \mu \mathrm{m}$

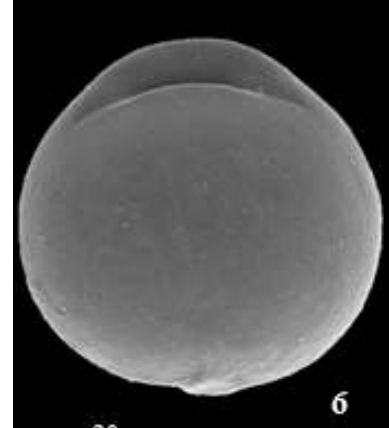

20

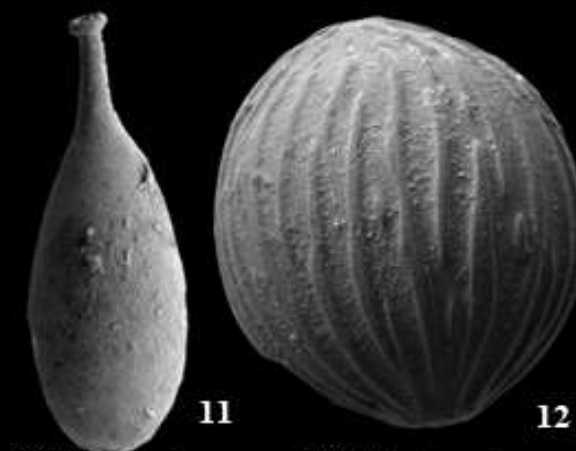

$50 \mu \mathrm{m}$

$100 \mu \mathrm{m}$
12 $100 \mathrm{um}$

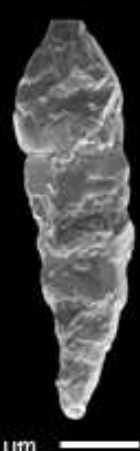

13

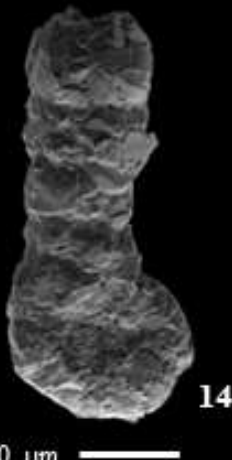

14
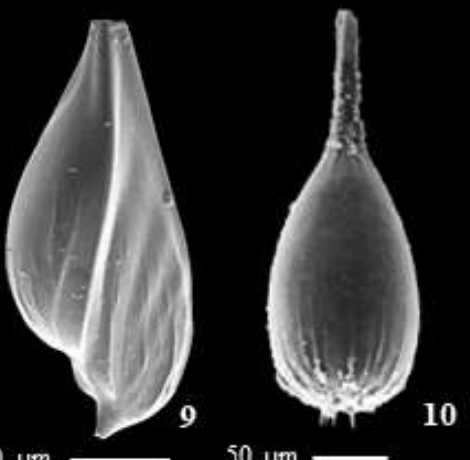

10
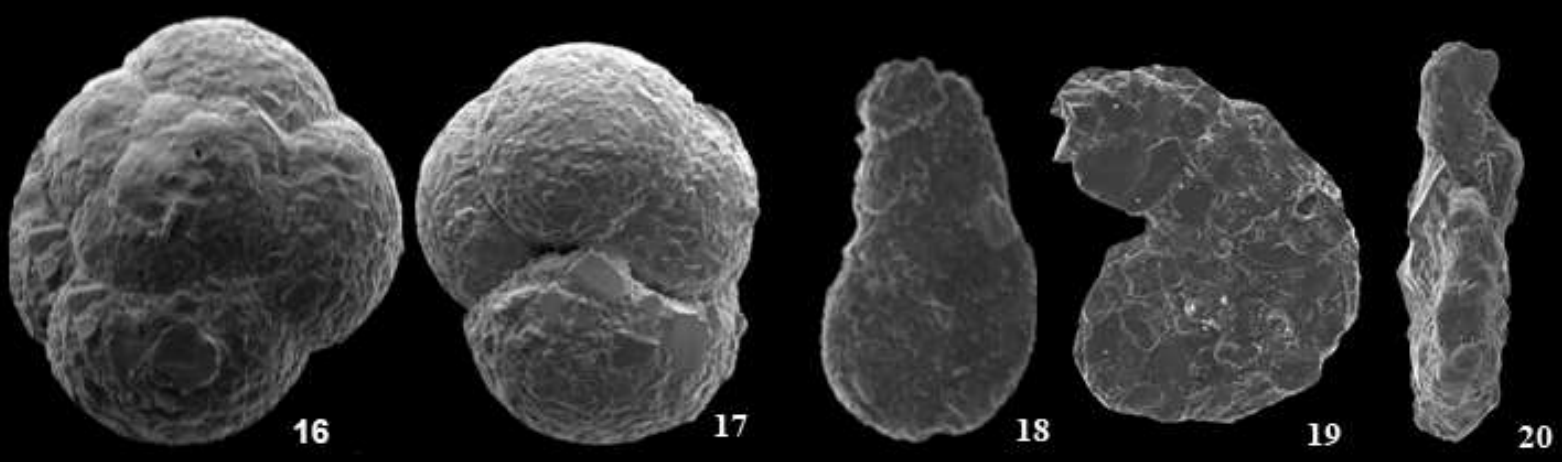

$100 \mu \mathrm{m}$

$100 \mu \mathrm{m}$

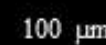

工 $100 \mu \mathrm{m}$

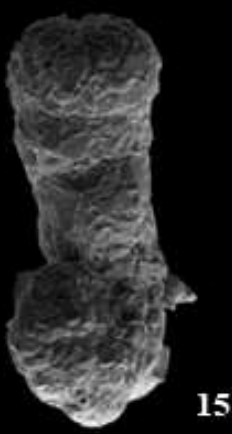

15

$100 \mu \mathrm{m}$

20

\section{Plate 2}

Plate 2. 1. Laryngosigma lactea (Walker and Jacob, 1798). 2. Lenticulina orbicularis (d'Orbigny, 1826); 3. Oolina globosa subsp. demissa McCulloch, $1977 ; 4$. Palliolatella bradyformis McCulloch, 1977; 5. Palliolatella fasciata subsp. carinata (Sidebottom, 1906); 6. Parafissurina abnormis Parr, 1950; 7. Parafissurina inaequalabiata Yassini and Jones, 1995; 8. Parafissurina lata (Wiesner, 1931); 9. Planularia patens (Brady, 1884); 10. Procerolagena setigera (Millett, 1901$) ; 11$. Reussoolina laevis (Montagu, 1803); 12. Vasiglobulina myristiformis (Williamson, 1858); 13. Acostata mariae (Acosta, 1940); 14. Ammobaculites balkwilli Haynes, 1973; 15. Ammobaculites exiguus Cushman and Brönnimann, 1948; 16-17. Ammoglobigerina pygmaea (Höglund, 1947); 18. Ammoscalaria pseudospiralis (Williamson, 1858); 20-21 Ammoscalaria runiana (Heron-Allen and Earland, 1916). 


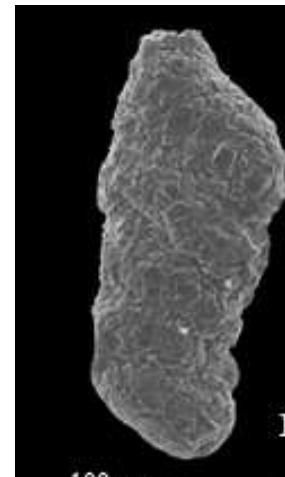

$100 \mu \mathrm{m}$
1 $100 \mu \mathrm{m}$

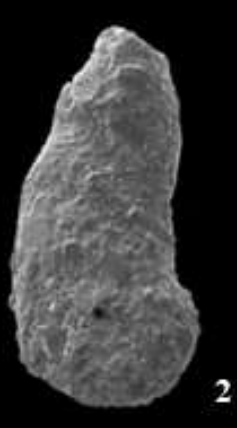

100

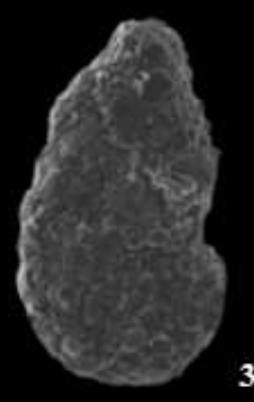

3 $100 \mu \mathrm{m}$

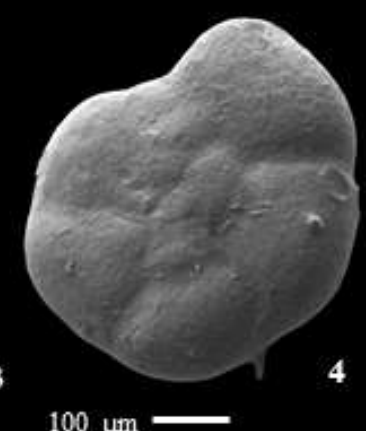

4

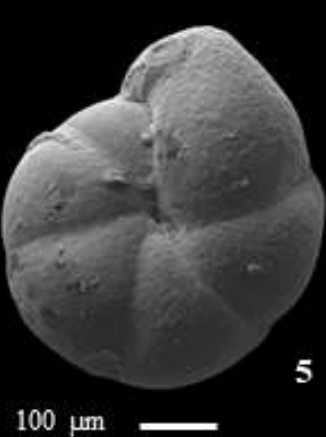

5

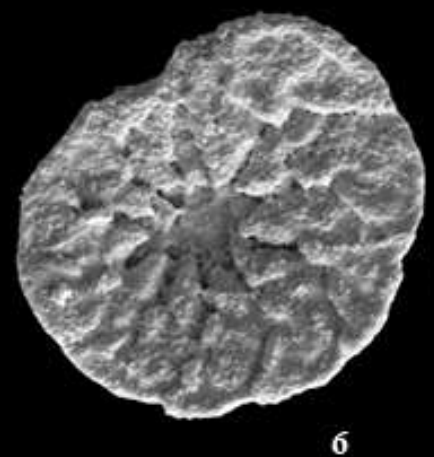

6

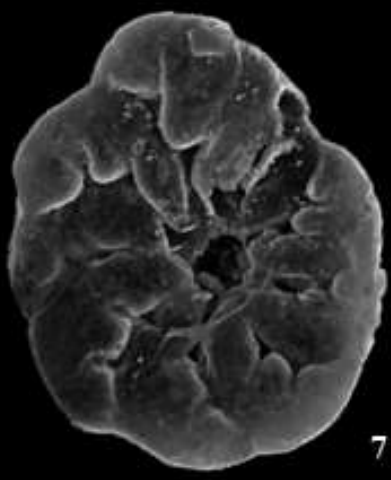

7

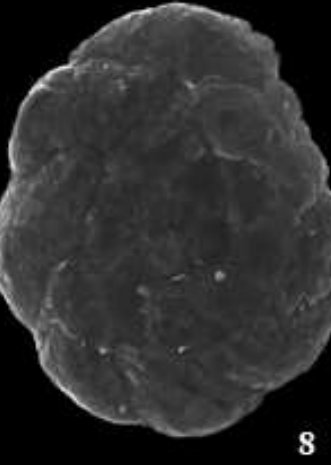

8
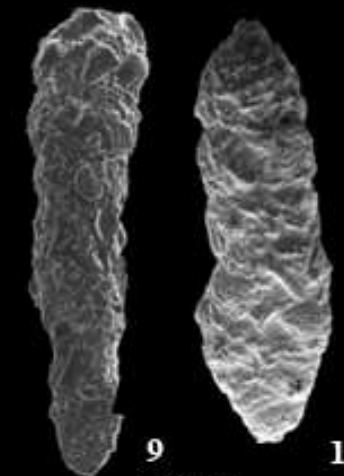

10

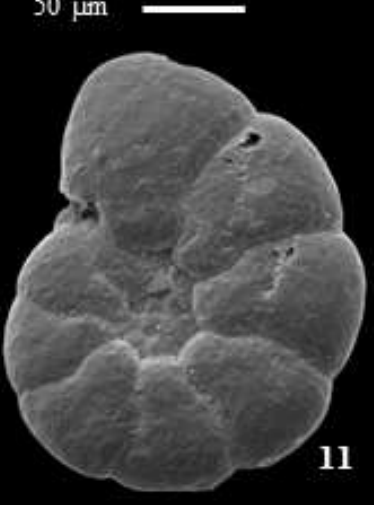

11

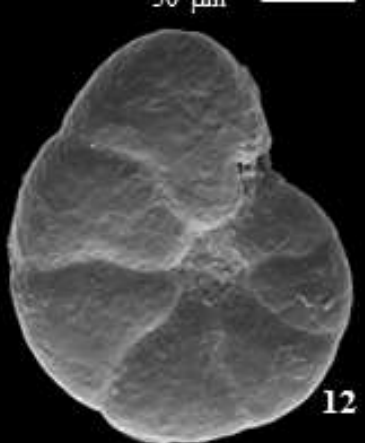

12

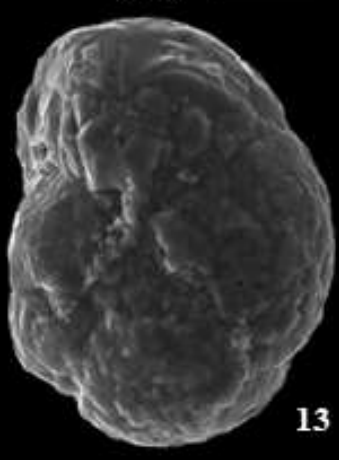

$100 \mu \mathrm{m}$

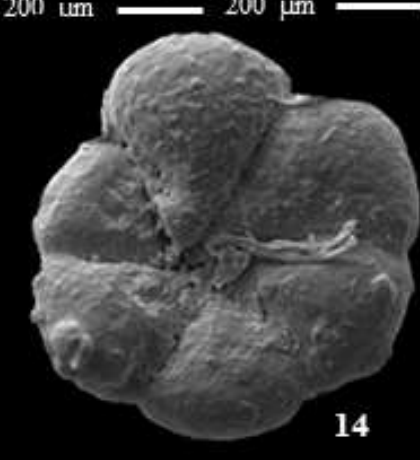

$100 \mu \mathrm{m}$

$100 \mu \mathrm{m}$

$100 \mu \mathrm{m}$

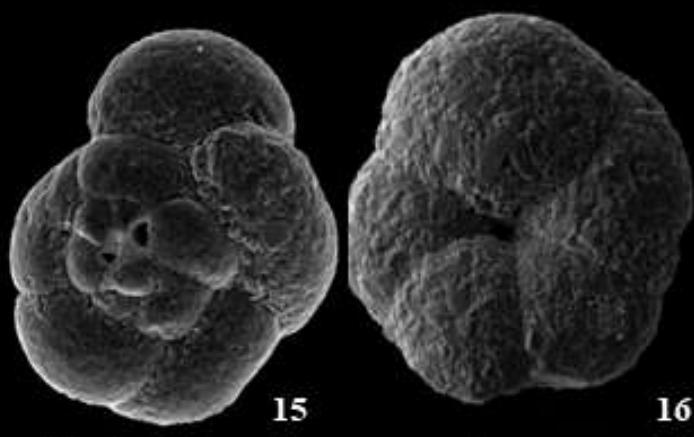

$100 \mu \mathrm{m}$

$20 \mu \mathrm{m}$
16

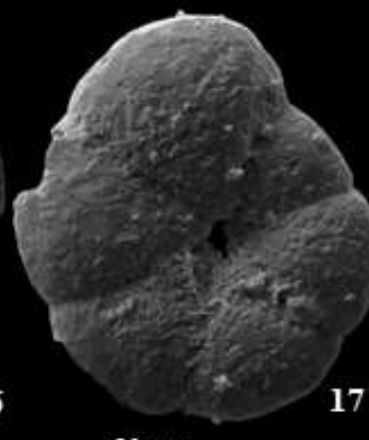

$20 \mu \mathrm{m}$

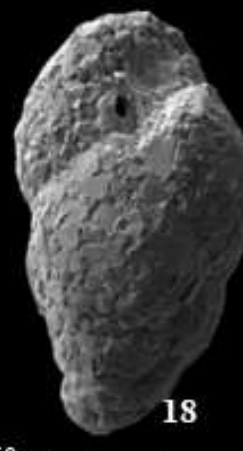

$50 \mu \mathrm{m}$

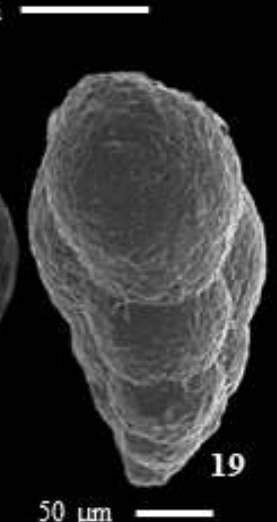

$50 \mu \mathrm{m}$

\section{Plate 3}

Plate 3. 1. Ammotium cassis (Parker, 1870); 2-3. Ammotium salsum (Cushman and Brönnimann, 1948); 4-5. Arenoparrella mexicana (Kornfeld, 1931$)$; 6. Asterotrochammina aspera Brönnimann and Zaninetti, 1984; 7-8. Asterotrochammina camposi Brönnimann, 1978; 9-10. Bigenerina (Bigenerina) nodosaria d'Orbigny, 1826; 11-12. Cribrostomoides jeffreysii (Williamson, 1858); 13. Cribrostomoides subglobosus (Cushman, 1910); 14-15. Cribrostomoides subturbinata (Cushman, 1920); 16. Deuterammina discorbis (Earland, 1934); 17. Deuterammina rotaliformis (Heron-Allen and Earland, 1911); 18-19. Eggerelloides scaber (Williamson, 1858). 


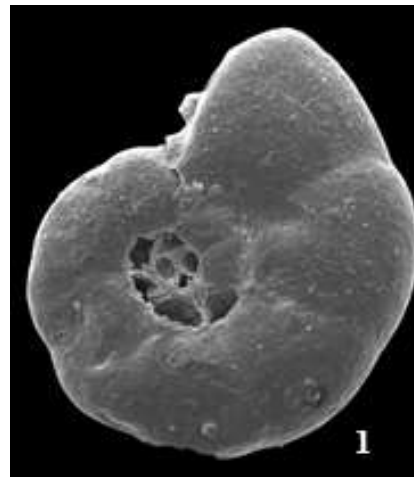

$100 \mu$

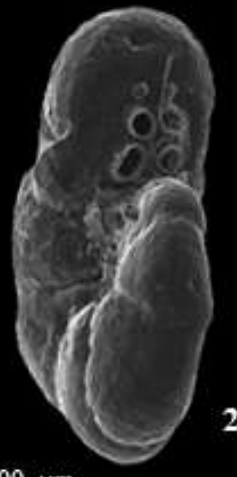

$100 \mu \mathrm{m}$
2

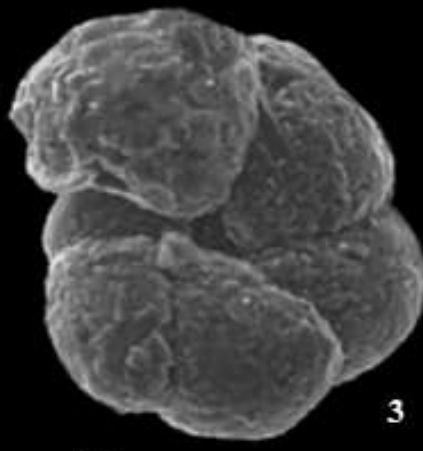

$100 \mu \mathrm{m}$

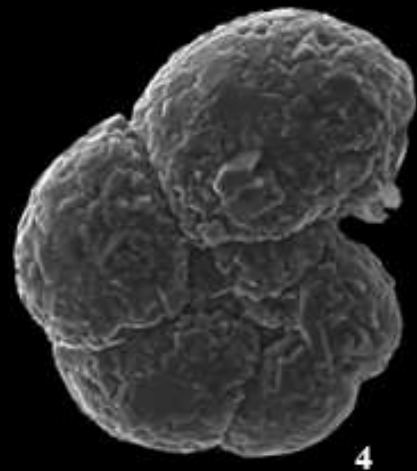

100

Pen

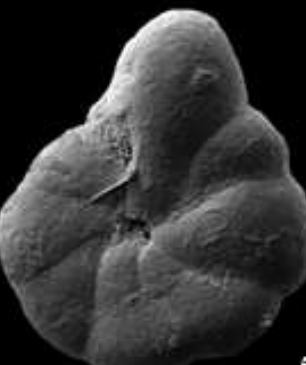

5

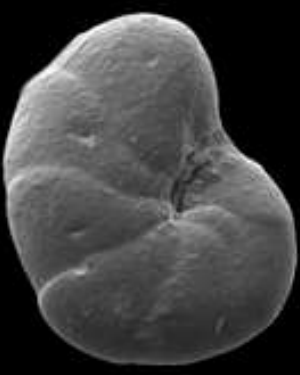

$100 \mu \mathrm{m}$
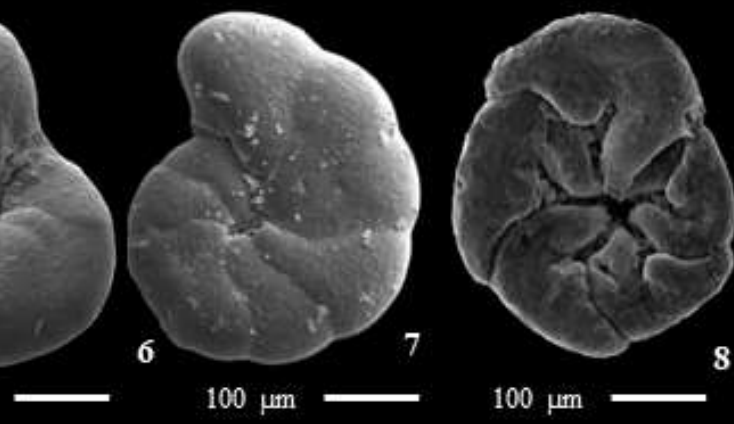

8

$100 \mu \mathrm{m}$

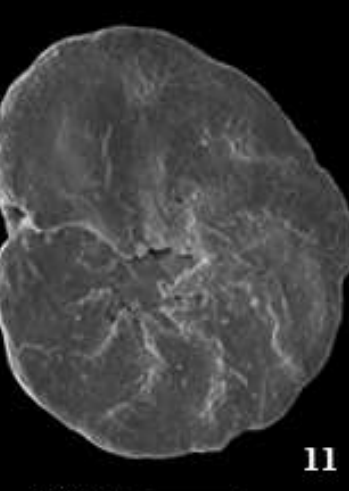

$100 \mu \mathrm{m}$

$100 \mu \mathrm{m}$

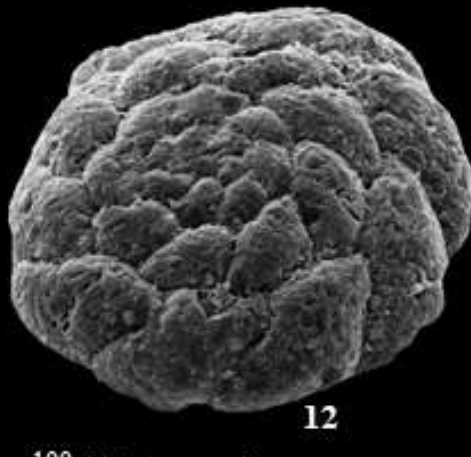

$100 \mu \mathrm{m}$
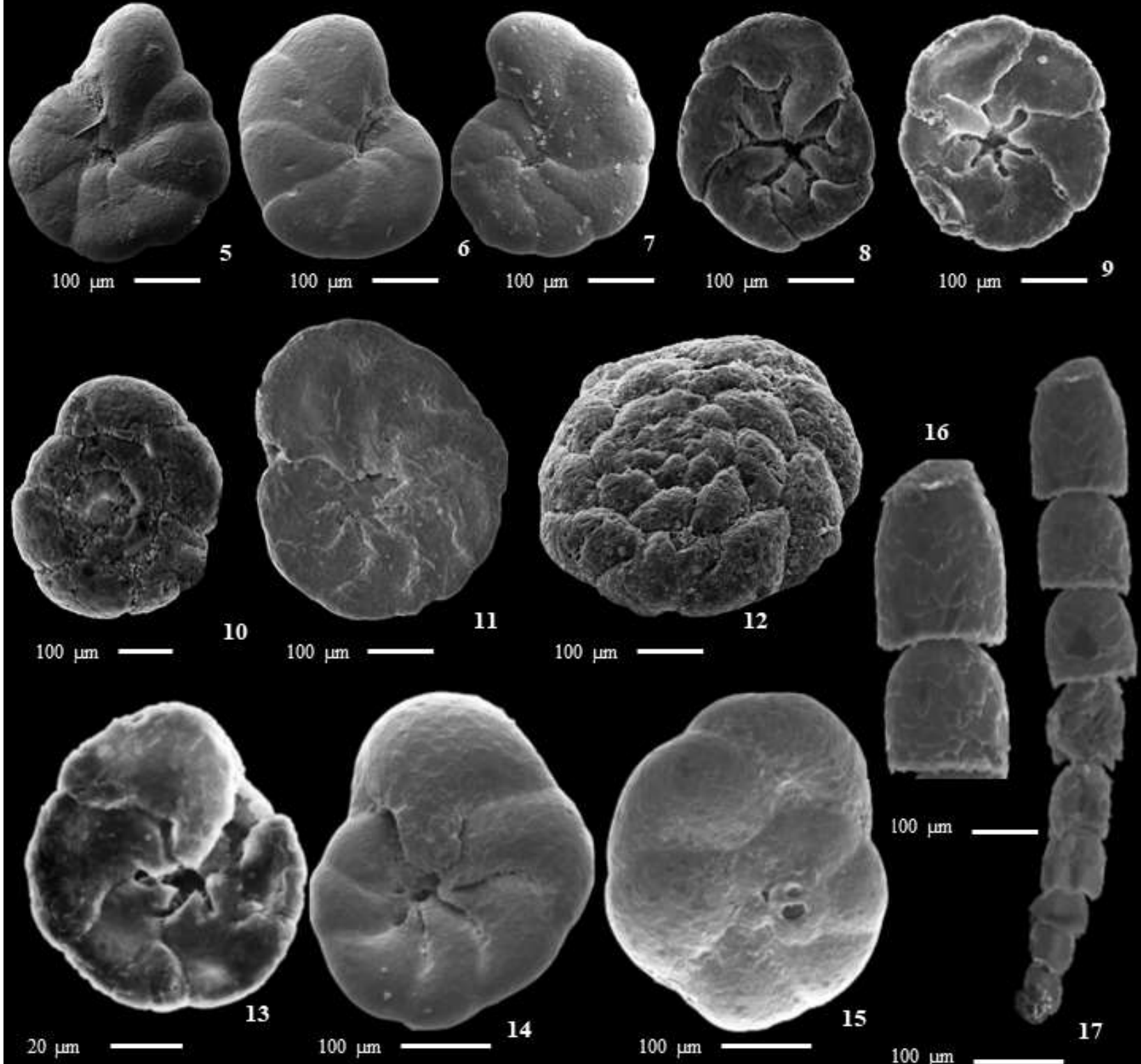

Plate 4

Plate 4. 1-2. Entzia macrescens (Brady, 1870); 3-4. Haplophragmoides manilaensis Andersen, 1952; 5. Haplophragmoides manilaensis Andersen, $1952 ; 6-7$. Haplophragmoides manilaensis Andersen, 1952; 8. Lepidodeuterammina celtica (Brönnimann and Whittaker, 1990); 9-10. Lepidodeuterammina eddystonensis (Brönnimann and Whittaker, 1990); 11-12. Lepidodeuterammina ochracea (Williamson, 1858); 13. Lepidodeuterammina plymouthensis (Brönnimann and Whittaker, 1990); 14-15. Lepidoparatrochammina lepida (Brönnimann and Whittaker, 1986); 16-17 - Leptobalysis catella (Höglund, 1947). 
Genus Deuterammina Brönniman emend. Brönnimann and Whittaker 1983

\section{Deuterammina discorbis (Earland, 1934)}

(Plate 3, Fig. 16)

Trochammina discorbis Earland, 1934, p. 104, Figs. 28-31.

Morphological description: Test with a trochoid spiral, composed of 3-4 convolutions, with four or five chambers in the last whorl. The dorsal side has a dome shape and exhibits all the whorls. The ventral side is flattened and show the chambers of the last convolution and a deep umbilicus. The sutures are depressed and recurved on the dorsal side and straight on the ventral side. The peripheral edge is rounded but compressed. The aperture, on the ventral side, is a slit at the end of the final chamber. The wall is finely agglutinated with much cement. Color ferruginous brownish. Diameter of about $60 \mu \mathrm{m}$.

Ecology and Distribution: It is rare and was found alive (up to $1 \%$ ) in the Aveiro inner and mid continental shelf.

\section{Deuterammina (Deuterammina) rotaliformis (Heron-Allen and} Earland, 1911)

(Plate 3, Fig. 17)

Trochammina rotaliformis Wright in Heron-Allen and Earland, 1911, p. 309.

Trochammina rotaliformis Heron-Allen and Earland; Murray, 1971, p. 39, pl. 12, figs. 1-5.

Deuterammina (Deuterammina) rotaliformis (Heron-Allen and Earland); Brönnimann and Whittaker 1983, pp. 349-352, figs. 1-12, 25.

Trochammina rotaliformis Wright in Heron-Allen and Earland; Hasegawa, 1988, p. 807, pl. 1, fig. 5 a-c.

Trochammina rotaliformis Wright in Heron-Allen and Earland; Levy et al., 1995, p. 19.

Morphological description: The test is trochospiral and presents a sinistral or dextral coiling; the last whorl shows 5 or 6 chambers. Sutures are depressed and retroverse, on the convex spiral side (with a dome form) and radial on the umbilical face. The umbilicus is narrow and deep. In the ventral face, each chamber has two simple apertures: the primary aperture is an interiomarginal-extraumbilical arch and the secondary one is axial-sutural, covered by the raised edge of a septum. These two apertures are not always easily observed due to the irregularity of the wall and are separated, forming as a whole an "aperture of Deuterammina type". The wall is agglutinated, yellowish-brown in color. Test diameter about 60-75 $\mu \mathrm{m}$.

Ecology and Distribution: It is present in the inner to mid shelf environments of different oceanic settings (Mathieu, 1986; Hasegawa, 1988; Brönnimann and Whittaker, 1990), living on coarse substrates (Murray, 1971). Levy et al. (1995)
RESEARCH PAPER reported its occurrence on the Portuguese continental shelf. It is a common living species (up to $4 \%$ ) in the Aveiro Lagoon inlet and in the nearby inner and mid shelf.

Genus Lepidodeuterammina Brönnimann and Whittaker, 1983 Lepidodeuterammina celtica (Brönnimann and Whittaker, 1990) (Plate 4, Fig. 8)

Deuterammina (Lepideuterammina) celtica Brönnimann and Whittaker, 1990, p. 119, pl. 4, figs. 13-16; pl. 8, fig. 4.

Morphological description: Lepidoid test with dextral coiling and little tightness; the test is composed of about sixteen chambers, arranged in six whorls, the last one can present more than five chambers. Its outer umbilical/spiral side is lobate and its peripheral margin rounded. Radial sutures are well defined. Umbilical depression has well-developed star arms. The umbilical lobe is separated from the main body of the kidney-shaped chamber by a sharp recess. The aperture is of Deuterammina type: a simple, primary, interiomarginal arc-shaped aperture in a peripheral position and a simple, secondary, elongated aperture in axial-sutural position under the elevation of an umbilical lobe. The test wall is thin, imperforated and relatively smooth; the agglutinated materials that compose the wall form an irregular mosaic, on both sides of the test. The umbilical/spiral diameter measures about $270 \mu \mathrm{m}$.

Ecology and Distribution: It occurs on the coasts of England, in the Plymouth region (Brönnimann and Whittaker, 1990). It is a common living species (up to 1\%) in the inner and mid shelf of Aveiro (TA up to 5\%).

Lepidodeuterammina eddystonensis (Brönnimann and Whittaker, 1990)

(Plate 4, Figs. 9-10)

Deuterammina (Lepidodeuterammina) eddystonensis Brönnimann and Whittaker, 1990, pp. 118-119

Morphological description: Dextral lepidoid test, loosely coiled, compressed with 5 or 6 chambers in the last whorl, with an open umbilicus on the ventral side with well-developed stellar branches. Both dorsal and ventral sutures are well marked. Aperture of Deuterammina-type. The primary aperture is an elongate slit in a subperipherical position and is separated from the secondary openings. The test has a subcircular and slightly lobate contour. The finely agglutinated and imperforated wall has smooth surface. Umbilical/ spiral diameter of about $160 \mu \mathrm{m}$.

Ecology and Distribution: It occurs on the coasts of England, in the Plymouth region (Brönnimann and Whittaker, 1990). It is common (up to $2 \%$ ) in the living assemblage of the external sector of the Aveiro Lagoon and the nearby inner and mid continental shelf. 


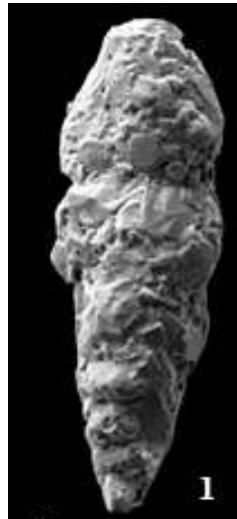

50 um
1

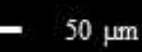

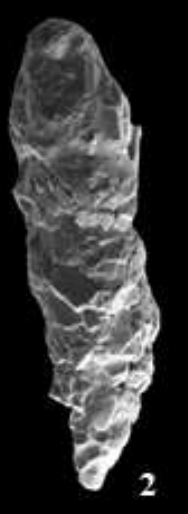

2

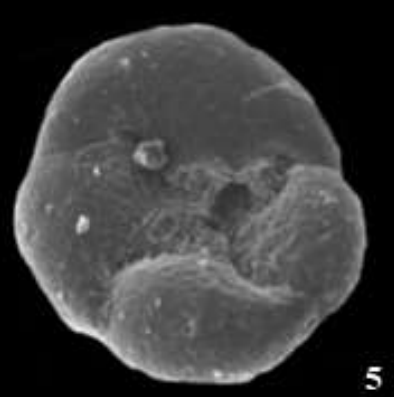

$150 \mu \mathrm{m}$

5

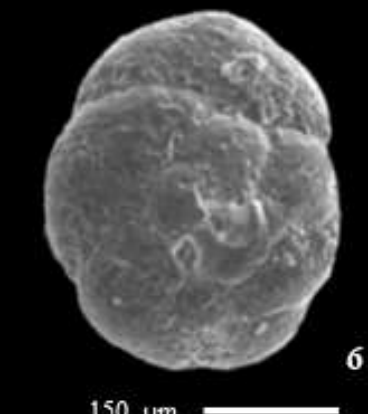

$150 \mu \mathrm{m}$

6

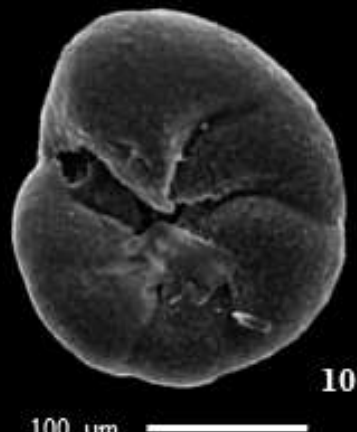

$100 \mu \mathrm{m}$

10
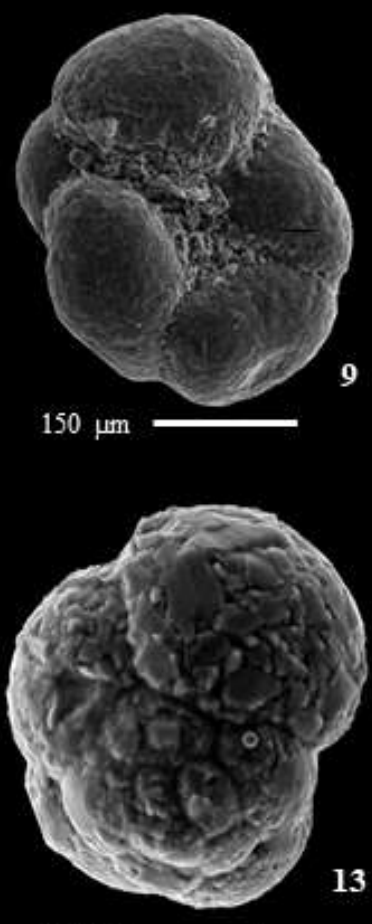

$50 \mu \mathrm{m}$

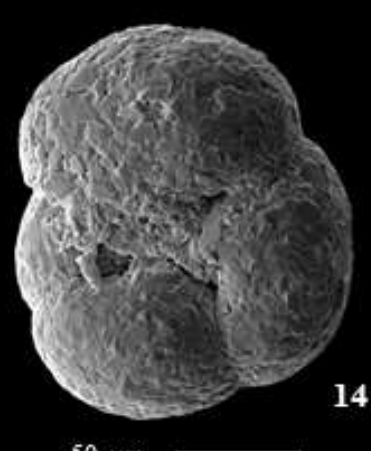

$50 \mu \mathrm{m}$
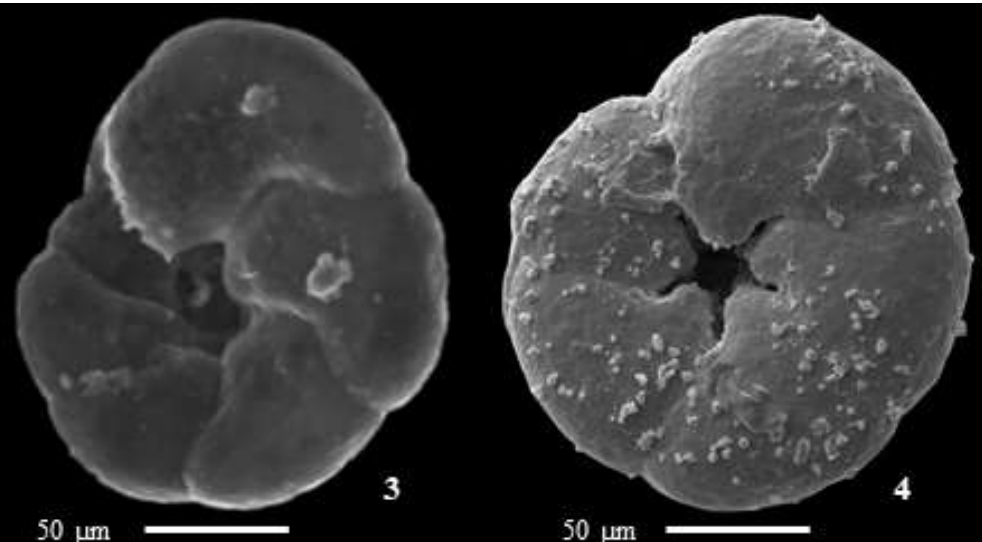

$50 \mu \mathrm{m}$
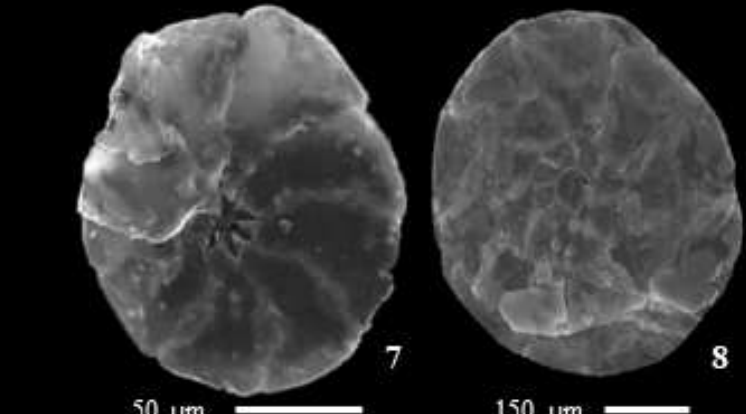

$150 \mu \mathrm{m}$

$50 \mu \mathrm{m}$

12

11

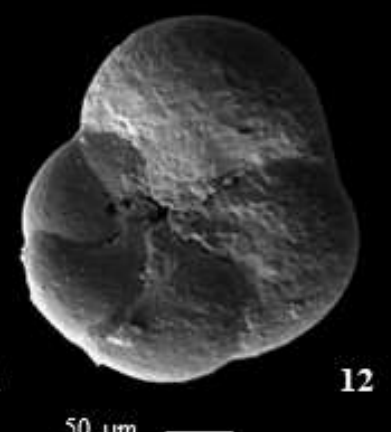

14

$50 \mu \mathrm{m}$

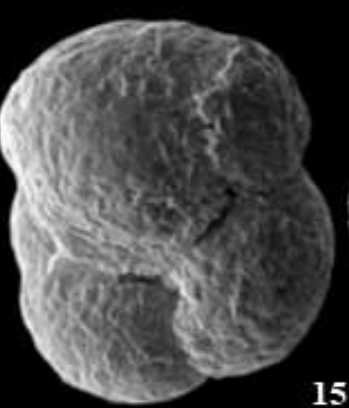

15

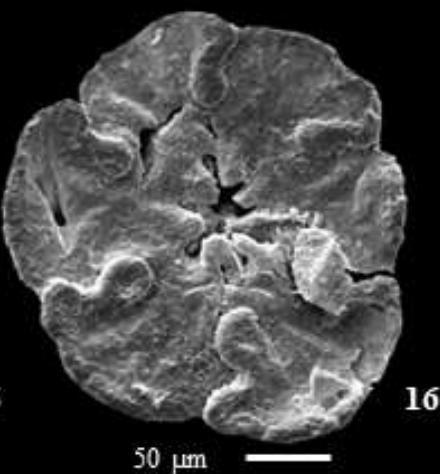

\section{Plate 5}

Plate 5. 1-2. Nodulina dentaliniformis (Brady, 1881); 3. Paratrochammina (Lepidoparatrochammina) barti Brönnimann and Whittaker, 1990; 4. Paratrochammina (Lepidoparatrochammina) haynesi (Atkinson, 1969); 5-6. Paratrochammina (Paratrochammina) wrighti Brönnimann and Whittaker, 1983; 7-8. Paratrochammina bartrami (Hedley, Hurdle and Burdett, 1967); 9. Paratrochammina (Paratrochammina) scotiaensis Brönnimann and Whittaker, 1988; 10. Paratrochammina obliqua Brönnimann and Zaninetti, 1984; 11-12. Portatrochammina karica (Shchedrina, 1946); 13-15. Portatrochammina murrayi Brönnimann and Zaninetti, $1984 ; 16$. Remaneica anglica Brönnimann and Whittaker, 1990. 

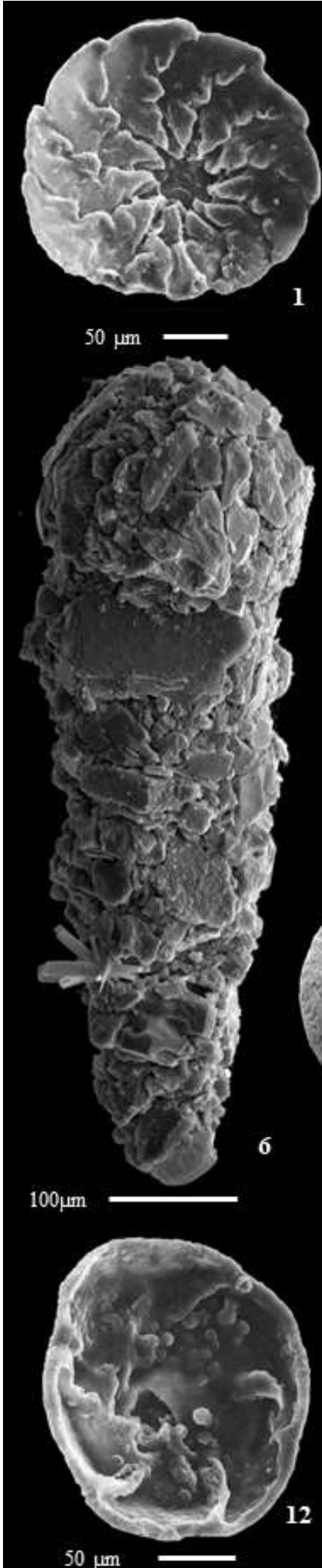
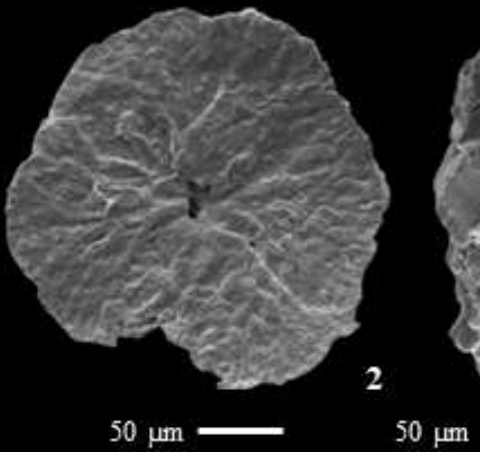

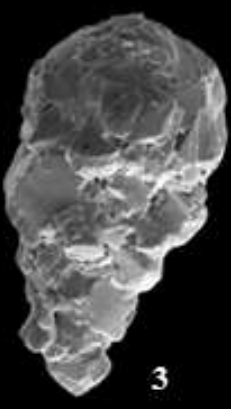

3
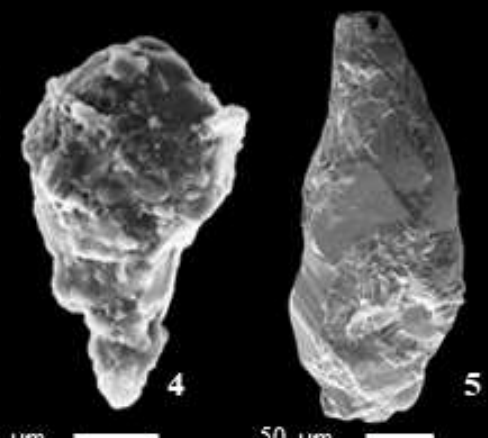

$50 \mu \mathrm{m}$

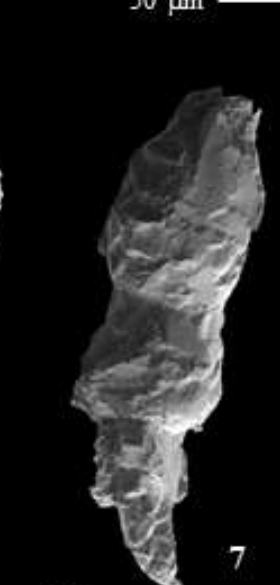

$200 \mu \mathrm{m}$

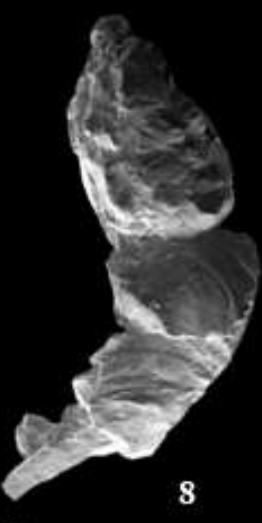

$200 \mu \mathrm{m}$

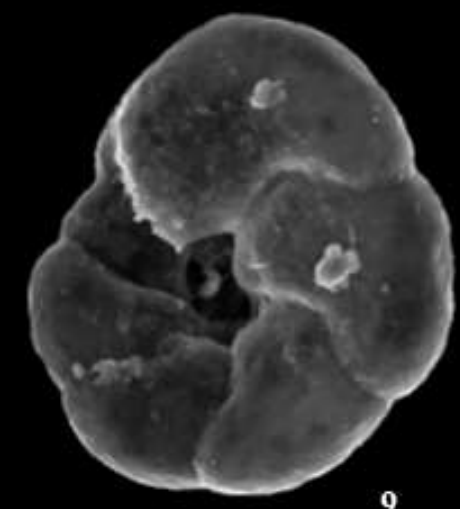

9
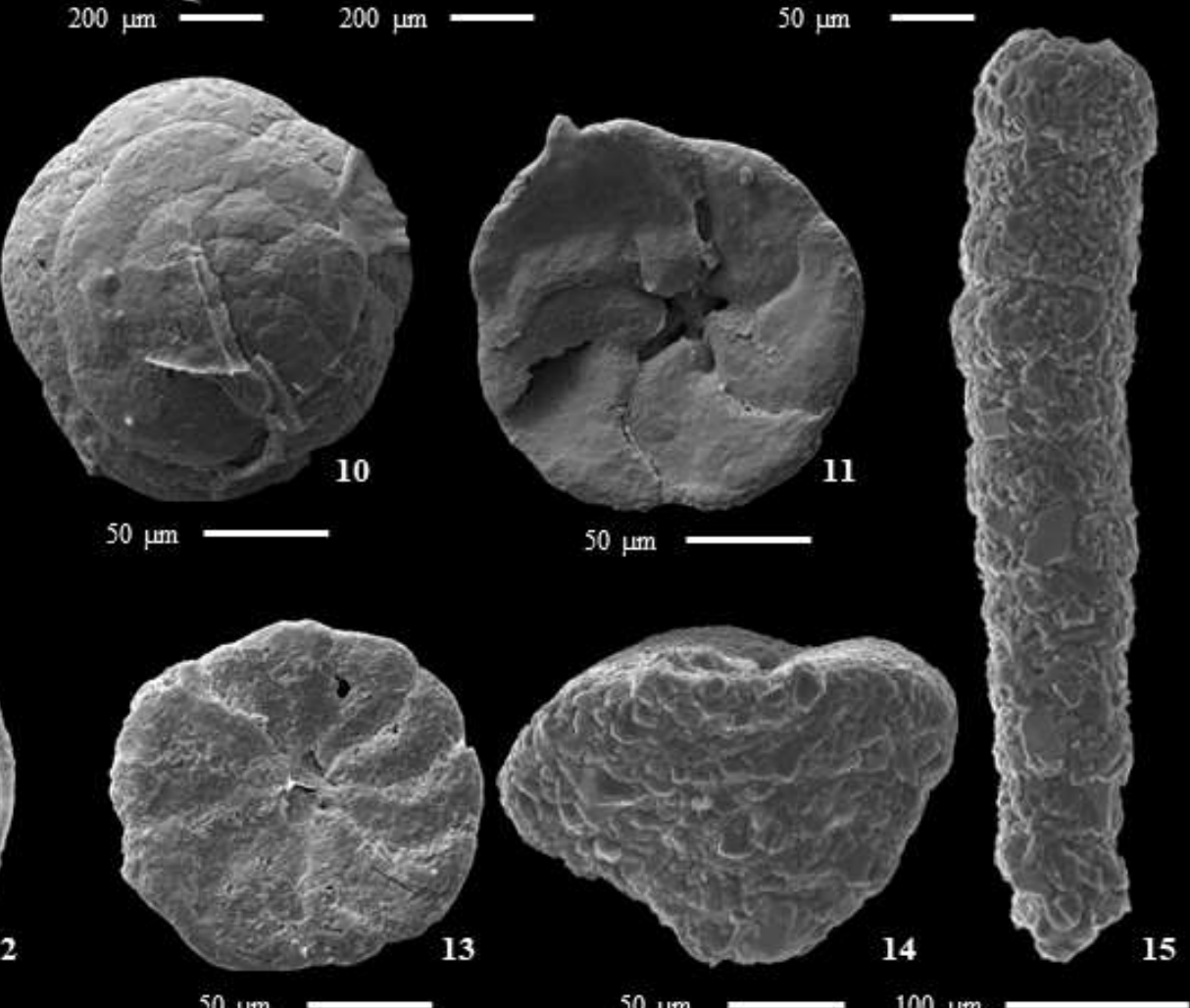

$50 \mu \mathrm{m}$
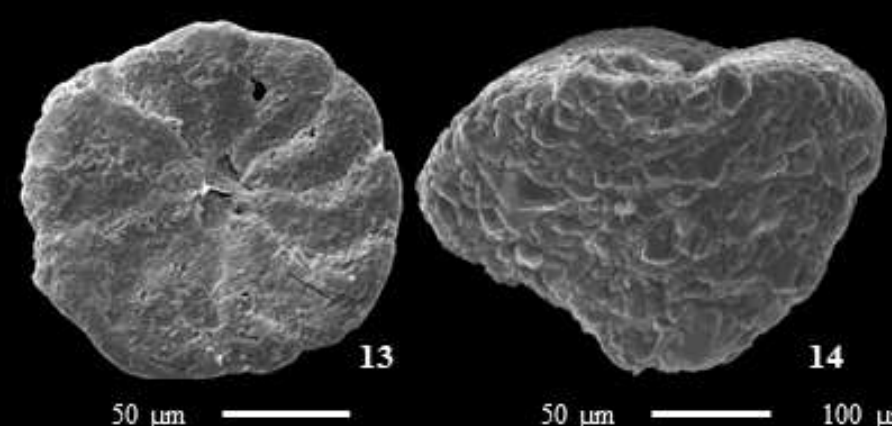

$50 \mu \mathrm{m}$

$100 \mu \mathrm{m}$

\section{Plate 6}

Plate 6. 1. Remaneica helgolandica Rhumbler, 1938; 2. Remaneicella gon₹alezi (Seiglie, 1964); 3-4. Reophax curtus Cushman, 1920; 5. Reophax fusiformis (Williamson, 1858); 6. Reophax nana Rhumbler, 1913; 7-8. Reophax scorpiurus Montfort, 1808; 9. Rotaliammina adaperta (Rhumbler, 1938$) ; 10-11$. Rotaliammina concava (Seiglie, 1964); 12. Rotaliammina petaloidea Brönnimann, Zaninetti and Whittaker, 1983; 13. Rotaliammina sigmoidea Wells, $1985 ; 14$. Sabulia conica (d'Orbigny, 1839); 15. Scherochorella moniliformis (Siddall, 1886). 

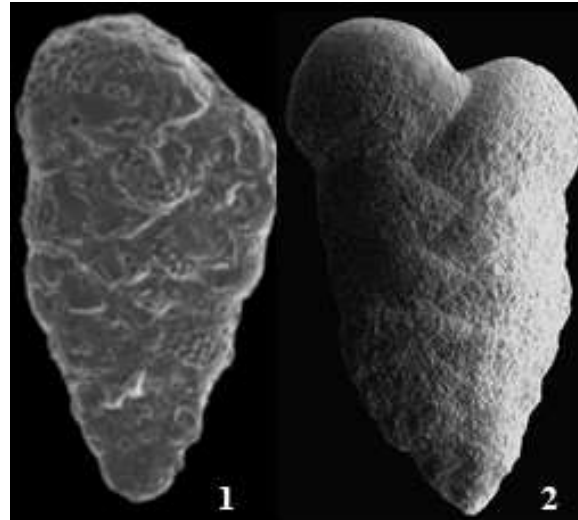

2

$100 \mu \mathrm{m}$

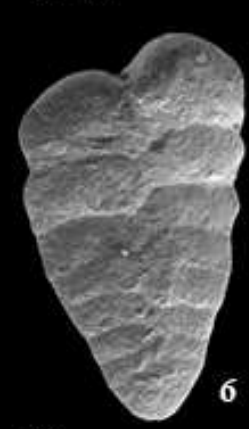

$100 \mu \mathrm{m}$
$100 \mu \mathrm{m}$

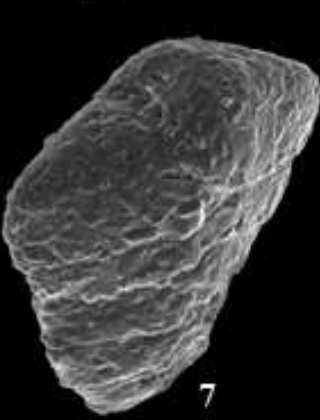

$100 \mu \mathrm{m}$

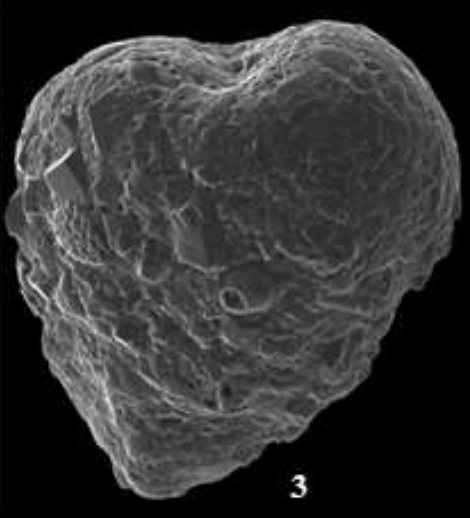

$100 \mu \mathrm{m}$

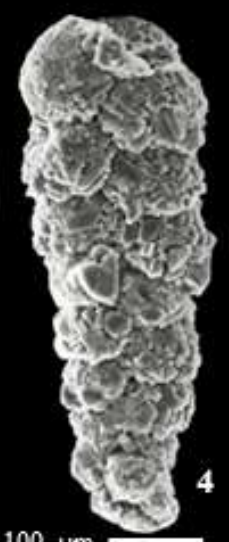

$100 \mu \mathrm{m}$

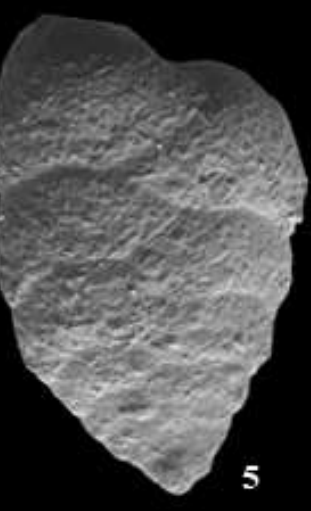

$100 \mu \mathrm{m}$

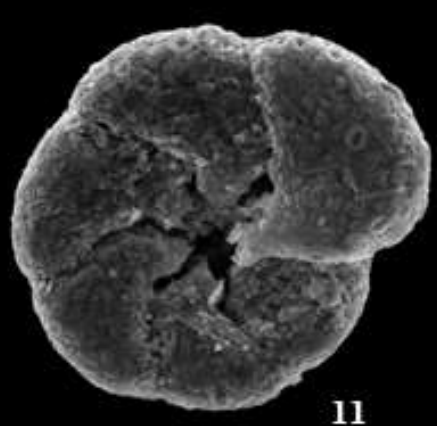

$50 \mu \mathrm{m}$
11

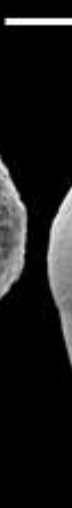

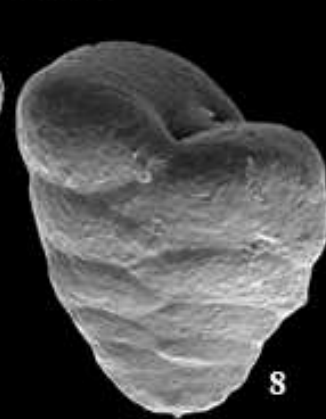

$100 \mu \mathrm{m}$

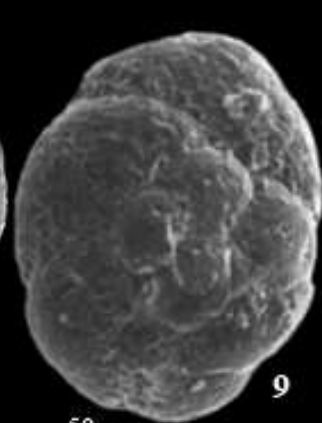

$50 \mu \mathrm{m}$

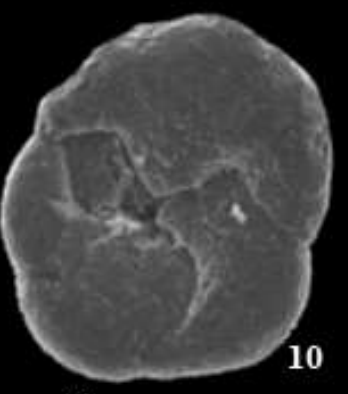

\section{0}
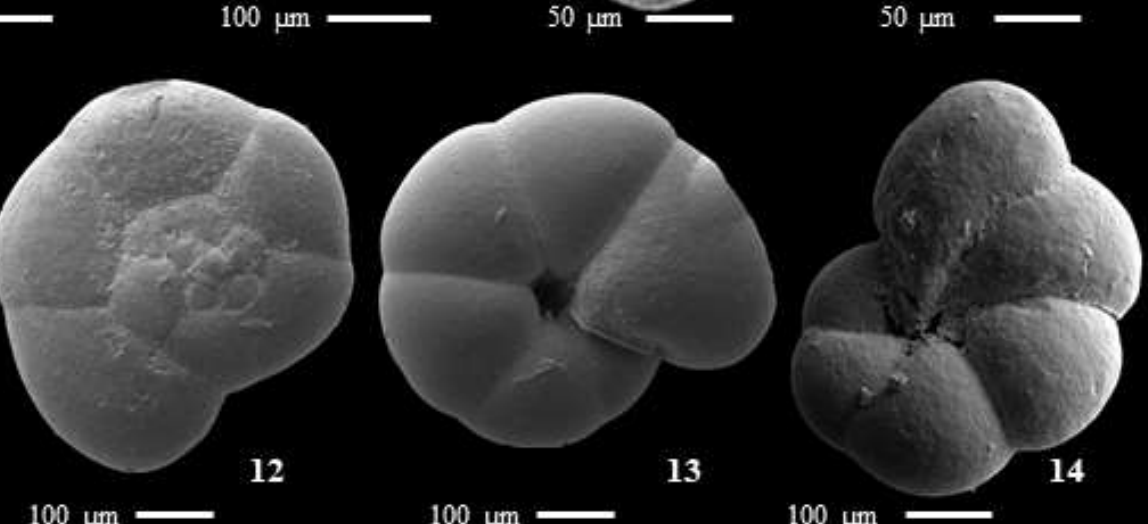

$100 \mu \mathrm{m}$

$100 \mu \mathrm{m}$

13

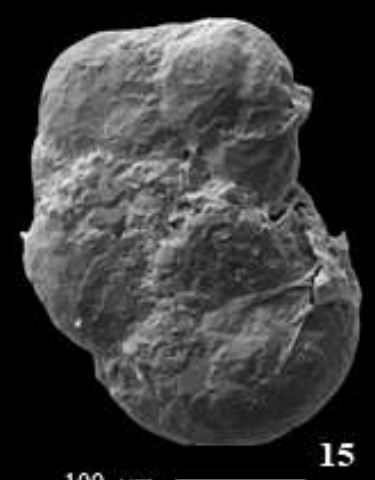

$100 \mu \mathrm{m}$

15

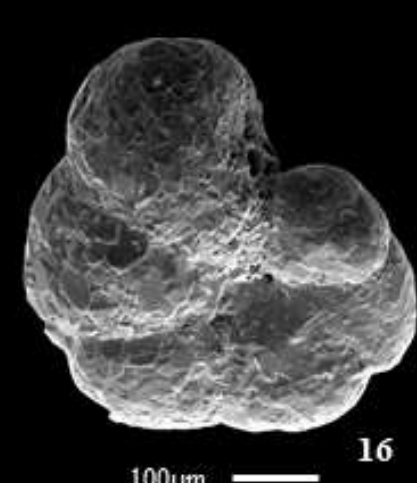

$100 \mu \mathrm{m}$

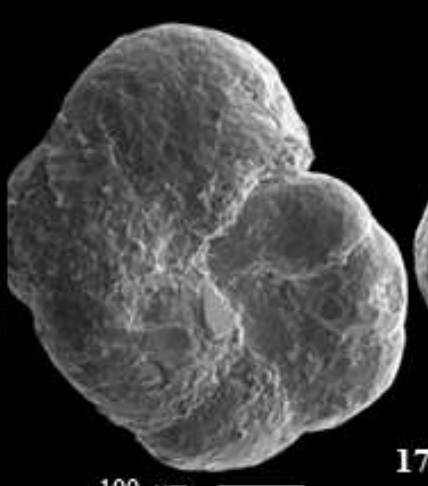

$100 \mu \mathrm{m}$

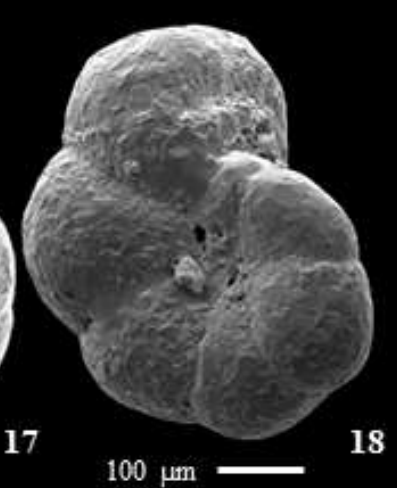

Plate 7

Plate 7. 1. Textularia agglutinans d'Orbigny, 1839; 2. Textularia communis (d'Orbigny in Fornasini, 1901); 3. Textularia deltoidea Reuss, 1850; 4. Textularia earlandi Parker, 1952; 5. Textularia gramen d'Orbigny, 1846; 6-7. Textularia sagittula Defrance, 1824; 8. Textularia truncata Höglund, 1947; 9-10. Tiphotrocha comprimata (Cushman and Brönnimann, 1948); 11. Trochammina astrifica Rhumbler, 1938; 12-13. Trochammina inflata (Montagu, 1808); 14. Trochammina lobata Cushman, 1944; 15. Trochamminita irregularis Cushman and Brönnimann, 1948; 16-17. Trochamminita salsa (Cushman and Brönnimann, 1948). 


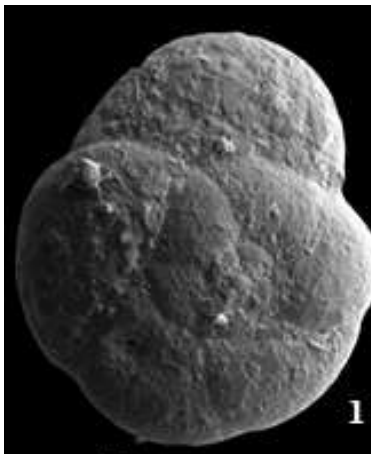

$100 \mu \mathrm{m}$

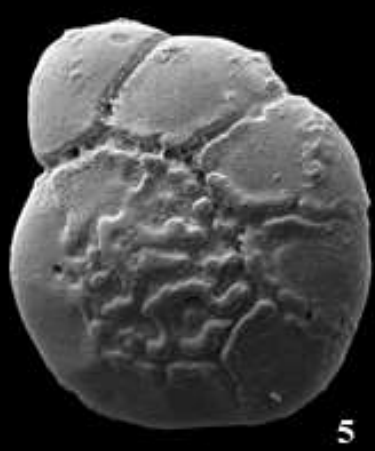

5

$100 \mu \mathrm{m}$

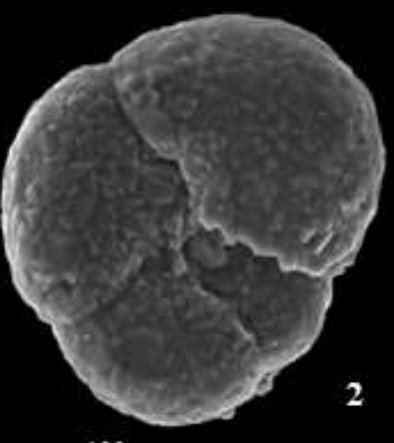

$100 \mu \mathrm{m}$

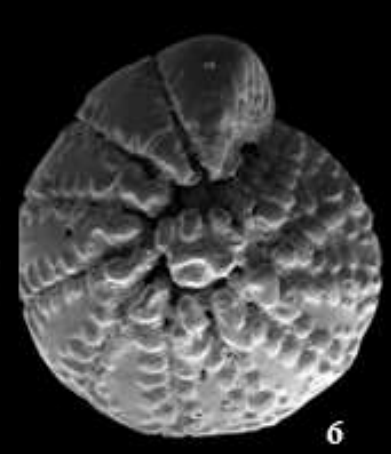

6

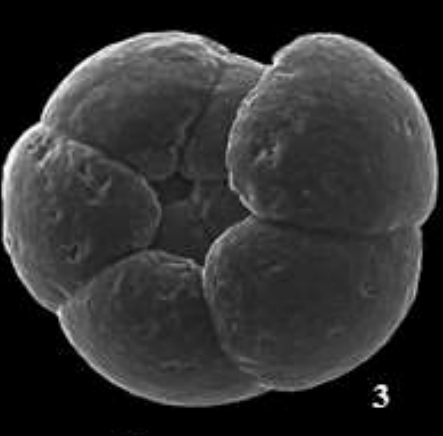

$50 \mu \mathrm{m}$
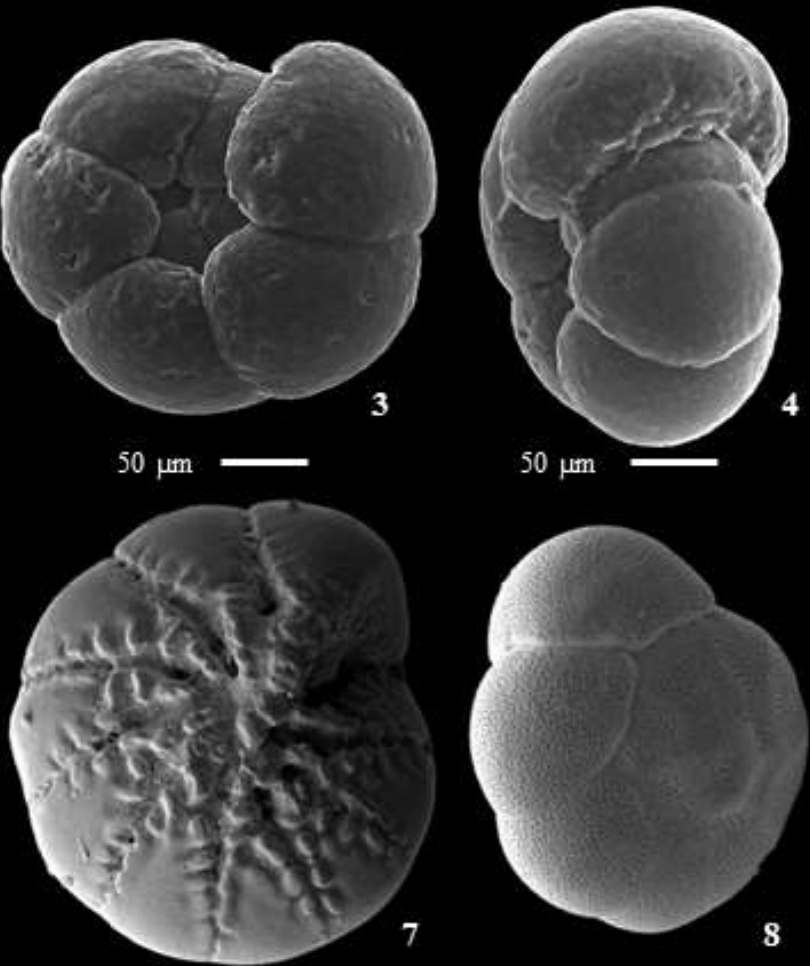

$100 \mu \mathrm{m}$

$100 \mu \mathrm{m}$
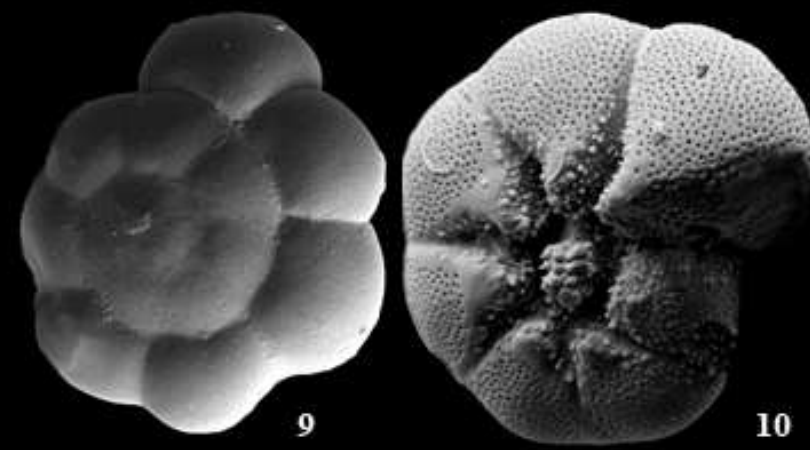

10

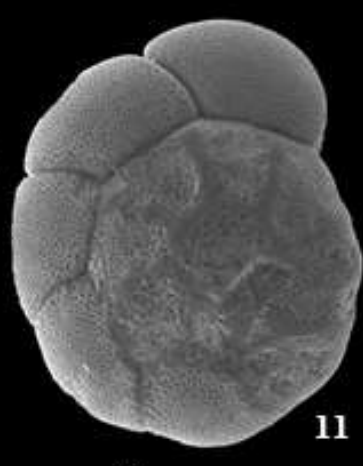

$50 \mu \mathrm{m}$

$50 \mu \mathrm{m}$

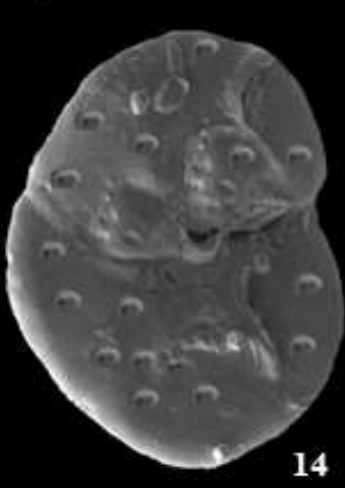

14

$100 \mu \mathrm{m}$

$100 \mu \mathrm{m}$

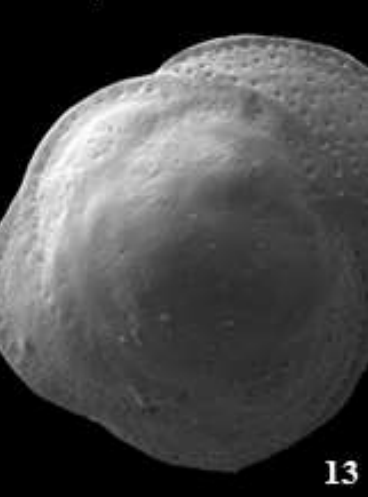

$\overline{2}$
13

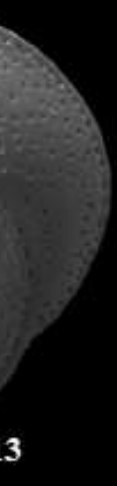

.
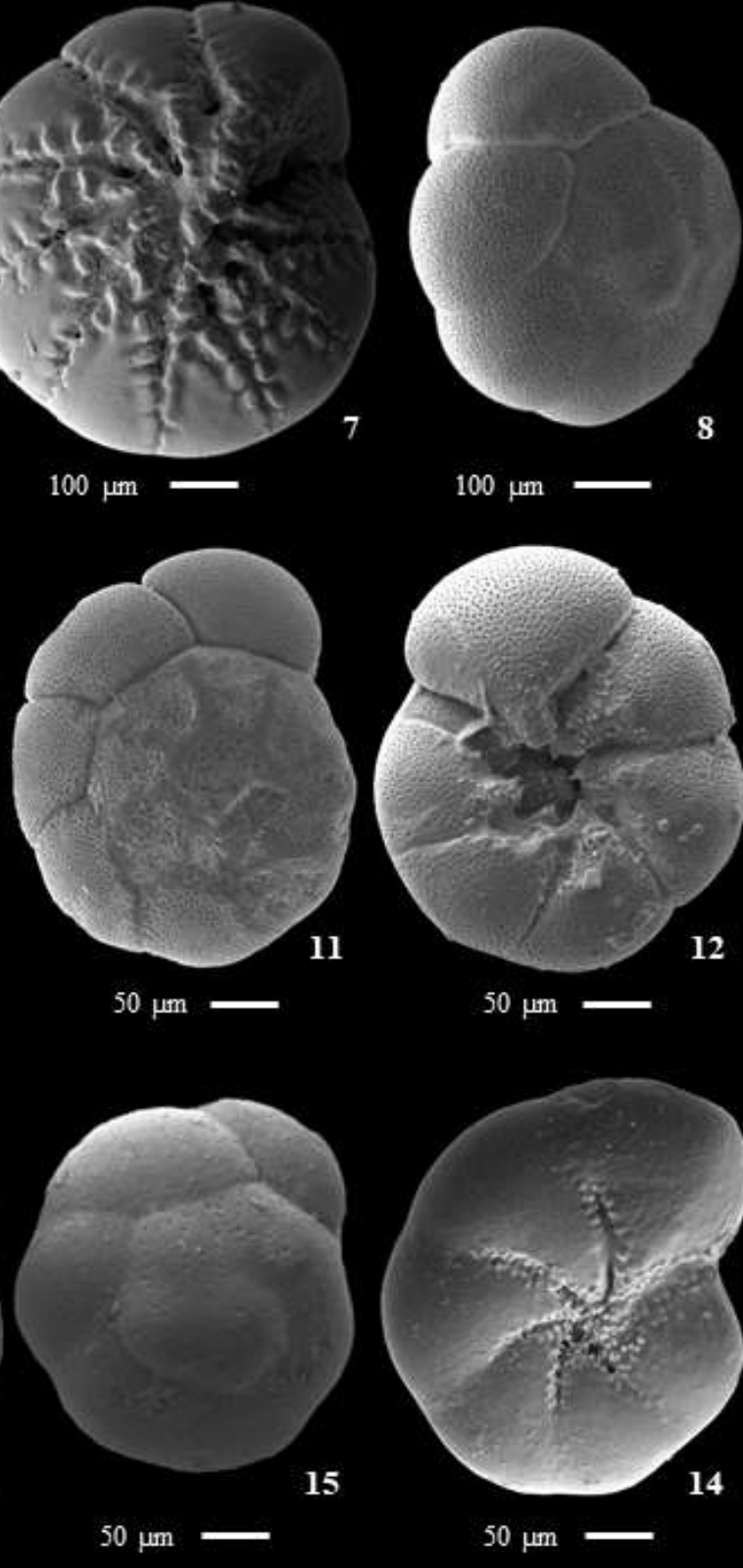

$100 \mu \mathrm{m}$
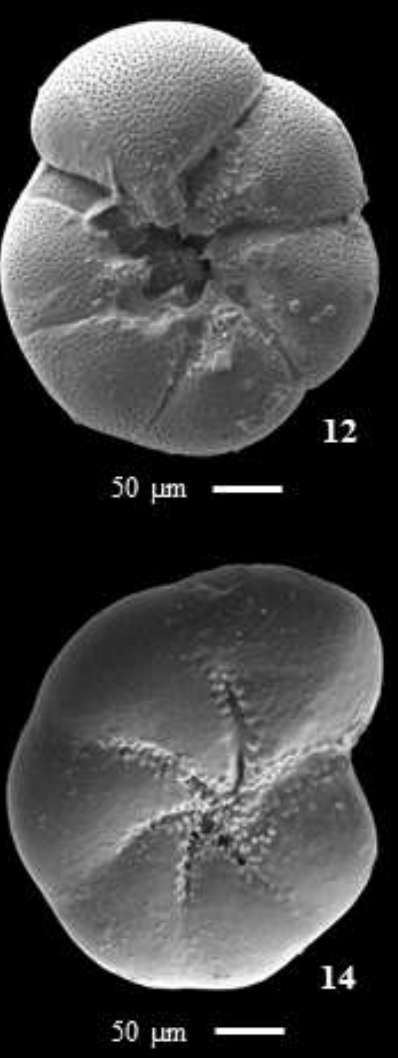

Plate 8

Plate 8. 1-2. Trochammina squamata Jones and Parker, 1860. 3-4. Veleroninoides scitulus (Brady, 1881); 5-6. Ammonia beccarii (Linnaeus, 1758). 7-8. Ammonia falsobeccarii (Rouvillois, 1974); 9-10. Ammonia parkinsoniana (d'Orbigny, 1839); 11-12. Ammonia tepida (Cushman, 1926); 13-14. Asterigerinata mamilla (Williamson, 1858); 15-16. Aubignyna perlucida (Heron-Allen and Earland, 1913). 
Lepidodeuterammina ochracea (Williamson, 1858)

(Plate 4, Figs. 11-12)

Rotalina ochracea Williamson, 1858, p. 55, pl. 4, fig. 112; pl. 5, fig. 113.

Deuterammina ochracea (Williamson); Levy et al., 1974, p. 130, pl. 1, figs. 1, 3.

Trochammina ochracea (Williamson); Boltovskoy et al., 1980, p. 52, pl. 33, figs. 20-22.

Trochammina ochracea (Williamson); Yassini and Jones, 1995, p. 72, figs. 1128-1129.

Morphological description: The lepidoid test with dextral coiling and little tightness has about sixteen chambers, arranged in six whorls; the last whorl can present more than five chambers. Its outer umbilical/spiral periphery is lobate and the peripheral margin rounded. Radial sutures are well defined. Umbilical depression has well-developed star arms. The umbilical lobe is separated from the main body of the kidney-shaped chamber by a sharp recess. The aperture is Deuterammina-like that is a simple, primary, interiomarginal arc-shaped aperture in a peripheral position and a simple, secondary, elongated aperture in axial-sutural position under the elevation of an umbilical lobe. The test wall is thin, imperforated and relatively smooth; the agglutinated materials that compose the wall form an irregular mosaic, on both sides of the test. The umbilical/spiral diameter measures about $270 \mu \mathrm{m}$.

Ecology and Distribution: It is common in brackish waters environments (Boltovskoy, 1957) and marine settings (Murray, 1970; Yassini and Jones, 1995). It is a quite common living species in Aveiro Lagoon and in the adjacent inner to mid continental shelf. It reaches very high relative abundance in the lagoon inlet (up to $52 \%$ ) under faster currents.

\section{Lepidodeuterammina plymouthensis (Brönnimann and} Whittaker, 1990)

(Plate 4, Fig. 13)

Deuterammina (Lepideuterammina) plymouthensis Brönnimann and Whittaker, 1990, pp. 117-118, pl. 3, figs. 1-14.

Morphological description: Lepidoid test with sinistral coiling. Its ventral axial depression is small and has star arms. The secondary apertures of the previous whorls are still visible within the umbilicus. It has well defined sutures, the spiral side being slightly curved. The trochoid loop consists of twenty chambers arranged in three whorls; the last whorl has six larger and higher chambers. On the spiral side, the chambers belonging to the initial stages of growth are more or less equidimensional. Each chamber has two apertures: the primary simple opening, with an interiomarginal arc shape, located approximately at the midway between the periphery and the axial depression and a simple secondary opening, with the form of an elongate arch, in an axial-
RESEARCH PAPER

sutural position. The primary opening is surrounded by a finely granular edge; the edges of the secondary aperture are also finely granular. The thin, imperforate, shiny and textured wall is agglutinated and consists of fine granular material. The umbilical/spiral diameter measures about 200 $\mu \mathrm{m}$.

Ecology and Distribution: It is common in coastal areas (Brönnimann and Whittaker, 1990) as well as at the inner and mid continental shelf off Aveiro (LA up to $0.5 \%$; TA up to $4 \%$ ).

\section{Lepidoparatrochammina lepida (Brönnimann and Whittaker,} 1986)

(Plate 4, Figs. 14-15)

\section{Paratrochammina (Lepidoparatrochammina) lepida Brönnimann and Whittaker, 1986, pp. 118-119.}

Morphological description: The free, trochospiral test, in form of a watch glass, has a dextral coiling. It consists of about 31 chambers (including the small subcircular prolocolus), arranged in more than three whorls; the last whorl has nine chambers. The spiral side has a low convexity and the umbilical side a small concavity. In side view, the test is very compressed but not carinate. The chambers are axially strongly compressed, excluding the proloculus and the initial segments. On both spiral and umbilical sides, the spiral and radial sutures are depressed and well defined. Axial depression is fairly large and shallow, but it does not have a star shape or small recesses in the interchamber sutures. The aperture is an elongated, simple and interiomarginal slit that communicates directly with an axial (umbilical) depression. The imperforate and smooth wall agglutinates small angular sedimentary particles on the spiral side and equidimensional grains on the umbilical side. The diameter of the test is approximately $230 \mu \mathrm{m}$.

Ecology and Distribution: It is common in England coastal areas (Brönnimann and Whittaker, 1990) and in the living assemblages (LA up to 4\%) of the mid continental shelf, off Aveiro.

Sub-Genus Paratrochammina (Lepidoparatrochammina) Brönnimann and Whittaker, 1986

\section{Paratrochammina (Lepidoparatrochammina) harti Brönnimann and Whittaker, 1990}

(Plate 5, Fig. 3)

Paratrochammina (Lepidoparatrochammina) harti Brönnimann and Whittaker, 1990, p. 113, pl. 2, figs. 1-4.

Morphological description: The lepidoid test, with a relatively tight sinistral coiling, has low convexity on the spiral side and small concavity on the umbilical side. Its peripheral margin is subcircular to slightly ovate. It has twelve chambers, very 
axially compressed and arranged in two whorls. The last whorl of the ventral side is composed of six chambers. The interchamber sutures are distinct and slightly curved, on the spiral side, being straight, on the umbilical face. The aperture, an elongated slit, Paratrochammina-type, is simple and interiomarginal. The axial apertural depression shows the openings of the first whorl, within sub-hexagonal edges, defined by small recesses of the radial sutures. The wall is agglutinated and imperforate.

Ecology and Distribution: It was found in England coastal areas (Brönnimann and Whittaker, 1990) and on the mid continental shelf, off Aveiro (LA up to $2 \%$ ) where it is rare.

\section{Paratrochammina (Lepidoparatrochammina) haynesi (Atkinson, 1969)}

(Plate 5, Fig. 4)

Paratrochammina haynesi Atkinson, 1969, pp. 528-531, fig. 6.1, a-c.

Paratrochammina (Lepidoparatrochammina) haynesi Atkinson; Brönnimann and Whittaker, 1986, pp. 119-123, pl. 2, figs. a-i.

Paratrochammina (Lepidoparatrochammina) haynesi Atkinson; Alve, 1990, p. 694, pl. 1, figs. 12-13.

Paratrochammina (Lepidoparatrochammina) haynesi Atkinson; Alve and Murray, 1994, pp. 21, 22-24, pl. 1, figs. 15-16.

Morphological description: Lepidoid test with relatively tight sinistral coiling. It has low convexity on the spiral side and small concavity on the umbilical side. The peripheral margin has a subcircular, slightly ovate shape. The test consists of about twenty-four axially intensely compressed chambers, which are arranged in three whorls. There are seven chambers on the final whorl, the latter having a crescent shape, both on the spiral and the ventral sides. On the umbilical side, the interchamber sutures, are well defined, curved and sinuous. The simple interiomarginal aperture is of Paratrochammina type. As the coiling is a little tight, the previous apertures are not fully covered by the remaining and functional aperture; however, they do not correspond to secondary apertures of the Deuterammina type, because they are not separated from the primary aperture. The wall is agglutinated and imperforate; it has on the spiral side a granular texture resulting from the existence of some large dispersed materials; while the umbilical side is smoother.

Ecology and Distribution: It occurs in coastal areas, being one of the dominant species in the intertidal zone of tidal channels at the British Isles (Brönnimann and Whittaker, 1990; Alve and Murray, 1994). It is a common living species in the lagoon and inner continental shelf of Aveiro. The highest percentage of living organisms (up to $12.5 \%$ ) was reached in the Aveiro Lagoon inlet under strong active currents, which suggest that it is resistant to strong hydrodynamics.

\section{Paratrochammina (Paratrochammina) wrighti Brönnimann and Whittaker, 1983}

(Plate 5, Fig. 5)
Paratrochammina (Paratrochammina) wrighti Brönnimann and Whittaker, 1983, pp. 356-357.

Morphological description: Test free, trochospiral, with rounded periphery and composed by four chambers in the last whorl. The coil is dextral, consisting of thirteen chambers arranged in three whorls; the edge contour is subcircular; the sutures are well defined; the single interiomarginal aperture, with crescentic shape, is covered by a central lip-like shape plate; the aperture is on the wall of the first and third chambers of the final whorl (of Paratrochammina type); the wall is finely agglutinated and imperforate. Diameter $\approx 130 \mu \mathrm{m}$.

Ecology and Distribution: Rare in the study area. It was found living in the external sector of Aveiro Lagoon.

Paratrochammina bartrami (Hedley, Hurdle and Burdett, 1967) (Plate 5, Figs. 6-7)

Trochammina bartrami Hedley, Hurdle and Burdett 1967, p. 111.

Rotaliammina bartrami (Hedley, Hurdle and Burdett); Hayward and Triggs, 1994, pp. 108-109, 113, pl. 1, figs. 10-11.

Morphological description: The test is small, trochospiral and concave-convex. It has a low dorsal spire and the ventral side is depressed and show an open umbilicus. Its contour is almost circular. On the spiral side, the chambers are numerous (between 24 and 32), being arranged in four and a half whorls (with 5-8 chambers); on the umbilical side, only the chambers of the final whorl are visible. The sutures are distinct and strong retroverse on the spiral side and sigmoid and slightly depressed on the ventral side. The thin, finely arenaceous wall is yellowish-brown in color. The aperture is interiomarginal and extra-umbilical; the umbilicus is wide, star-shaped, with acute flaps coinciding with the sutures of each whorl. The test diameter measures about $130 \mu \mathrm{m}$.

Ecology and Distribution: it was found in tidal channels, on clay substrates or fine sands, under low salinity conditions than the marine ones (Hayward and Triggs, 1994). It was found living (up to 14\%) in the inner continental shelf off Aveiro.

Paratrochammina (Paratrochammina) scotiaensis Brönnimann and Whittaker, 1988

(Plate 5, Figs. 8-9)

Paratrochammina (Paratrochammina) scotiaensis Brönnimann and Whittaker, 1988, pp. 48-50.

Morphological description: Test free, trochospiral, conical; the coil is dextral, consisting of $\approx 15$ chambers, including the proloculus and arranged in three and a half whorls. The whorl is composed by four chambers; the edge contour is rounded and lobate; the sutures are well defined; the umbilicus is a shallow depression. The interiomarginal aperture is covered by a rim of Paratrochammina type. Wall agglutinated. Diameter $230 \mu \mathrm{m}$.

Ecology and Distribution: Rare; it was found living in the Aveiro Lagoon inlet. 


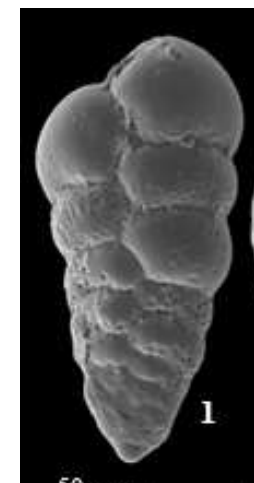

$50 \mu \mathrm{m}$

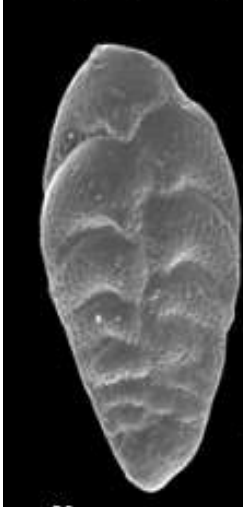

$50 \mu \mathrm{m}$

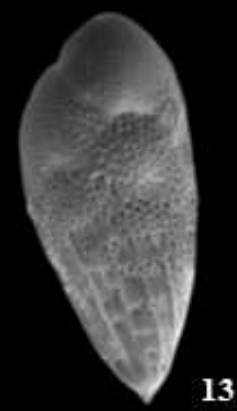

13

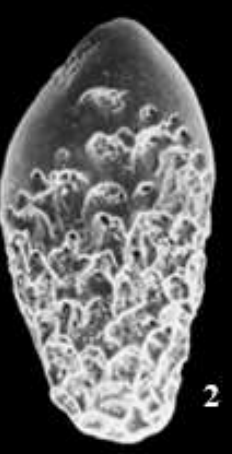

$50 \mu \mathrm{m}$
3

$50 \mu \mathrm{m}$

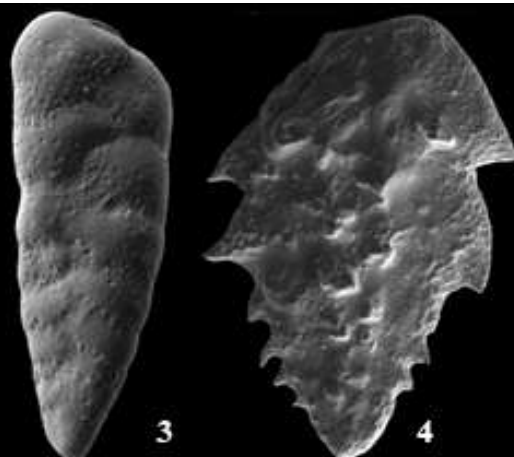

$50 \mu \mathrm{m}$

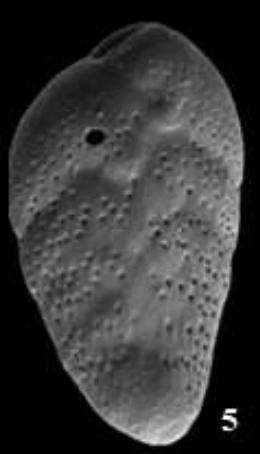

$50 \mu \mathrm{m}$

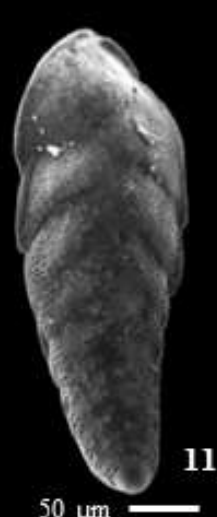

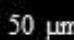

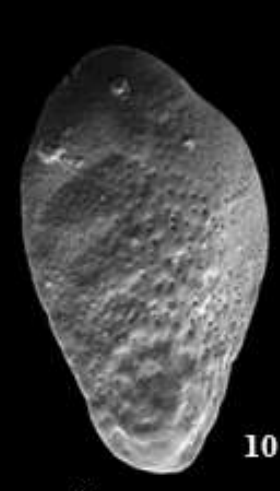

$50 \mu \mathrm{m}$
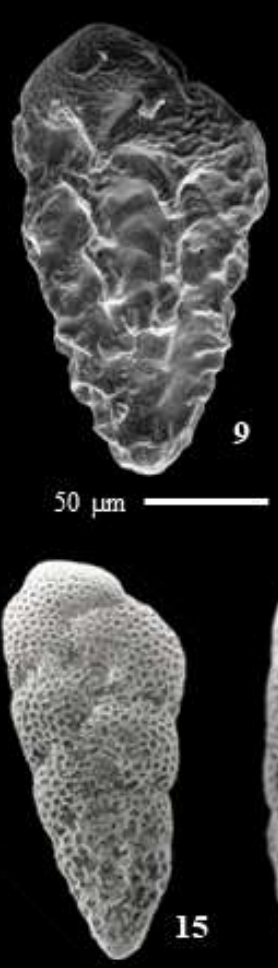

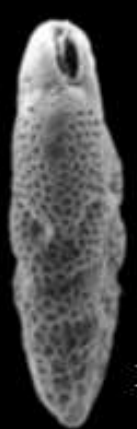

16

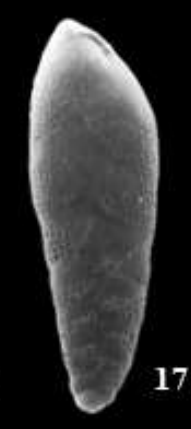

17

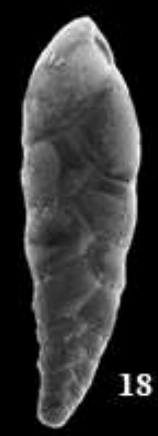

$50 \mu \mathrm{m}$

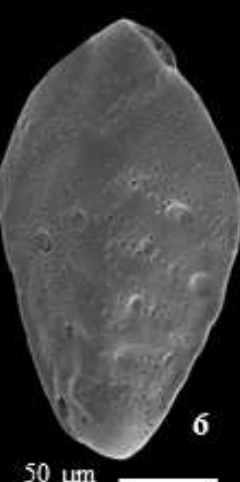

$50 \mu \mathrm{m}$

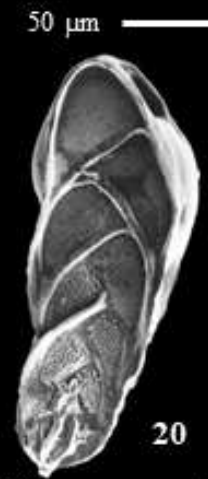

$50 . \mathrm{m}$

20

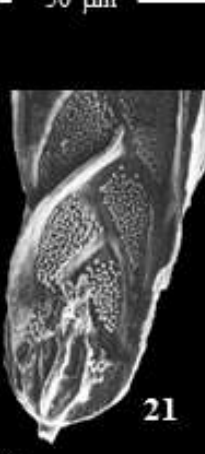

$50 \mu \mathrm{m}$
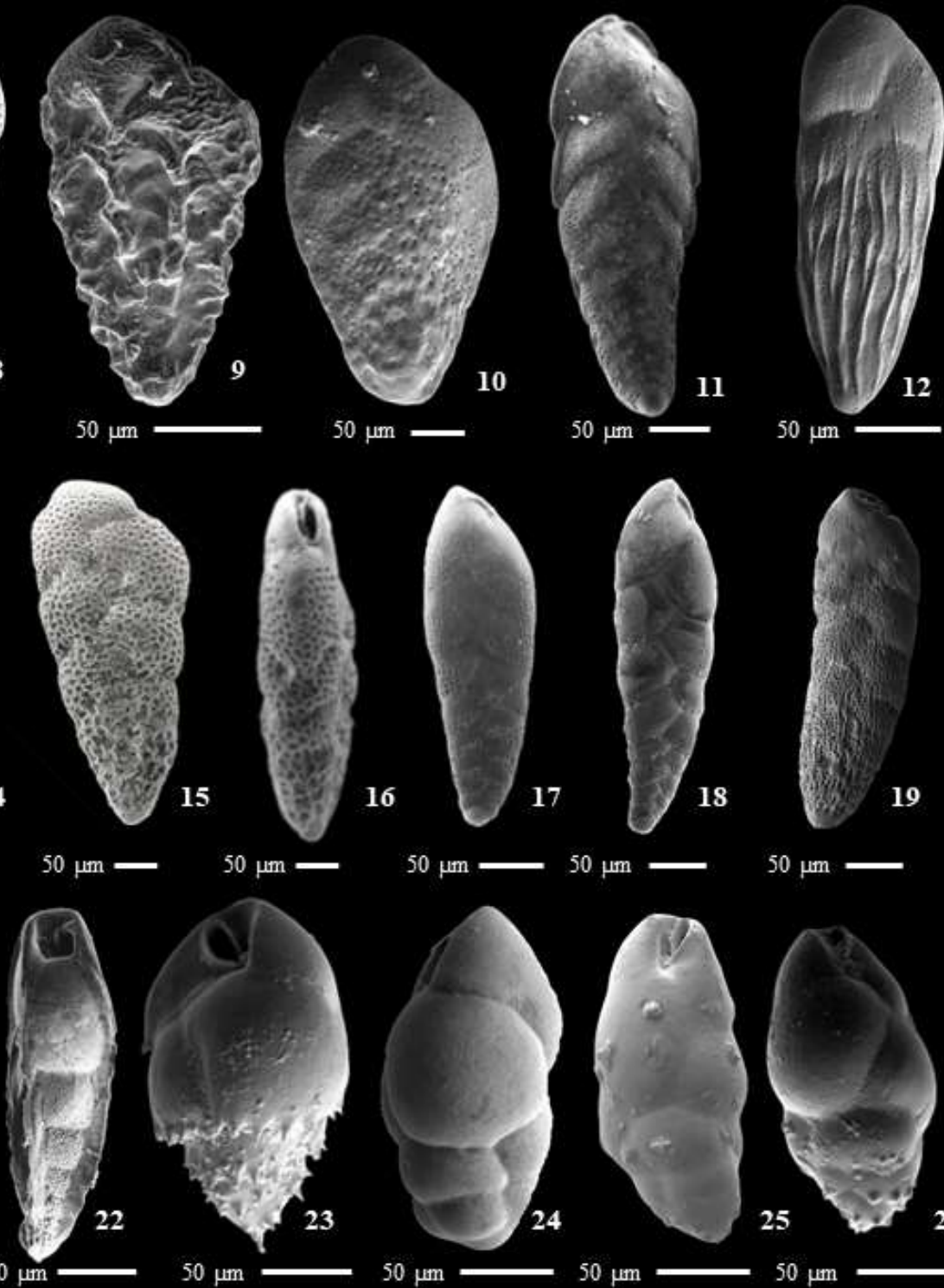

$50 \mu \mathrm{m}$

12

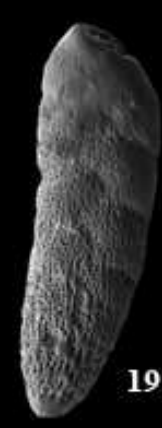

$50 \mu \mathrm{m}$

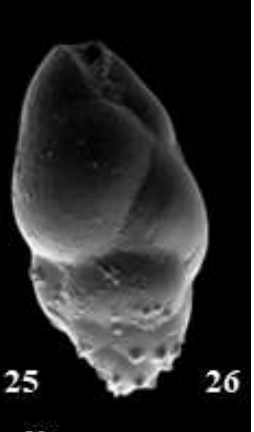

$50 \mu \mathrm{m}$

\section{Plate 9}

Plate 9. 1. Bolivina abbreviata Heron-Allen and Earland, 1924; 2. Bolivina albatrossi Cushman, 1922; 3. Bolivina compacta Sidebottom, 1905; 4. Bolivina difformis (Williamson, 1858); 5-6. Bolivina dilatata Reuss, 1850; 6. Bolivina goesii Cushman, 1922; 7. Bolivina ordinaria Phleger and Parker, 1952; 8. Bolivina psendolobata Yassini and Jones, 1995; 9. Bolivina pseudoplicata Heron-Allen and Earland, 1930; 10. Bolivina skagerrakensis Qvale and Nigam, 1985; 11. Bolivina spathulata (Williamson, 1858); 12. Bolivina striatula Cushman, 1922; 13-14. Bolivina subaenariensis Cushman, 1922; 15-16. Bolivina variabilis (Williamson, 1858); 17. Bolivinella seminuda (Cushman, 1911); 18. Bolivinellina pseudopunctata (Höglund, 1947); 19. Bolivinellina translucens (Phleger and Parker, 1951); 20-22. Bolivinita quadrilatera (Schwager, 1866); 23. Bulimina aculeata d'Orbigny, 1826; 24. Bulimina elegans d'Orbigny in Parker, Jones and Brady, 1865; 25. Bulimina elongata d'Orbigny, 1846; 26. Bulimina gibba Fornasini, 1900. 
RESEARCH PAPER
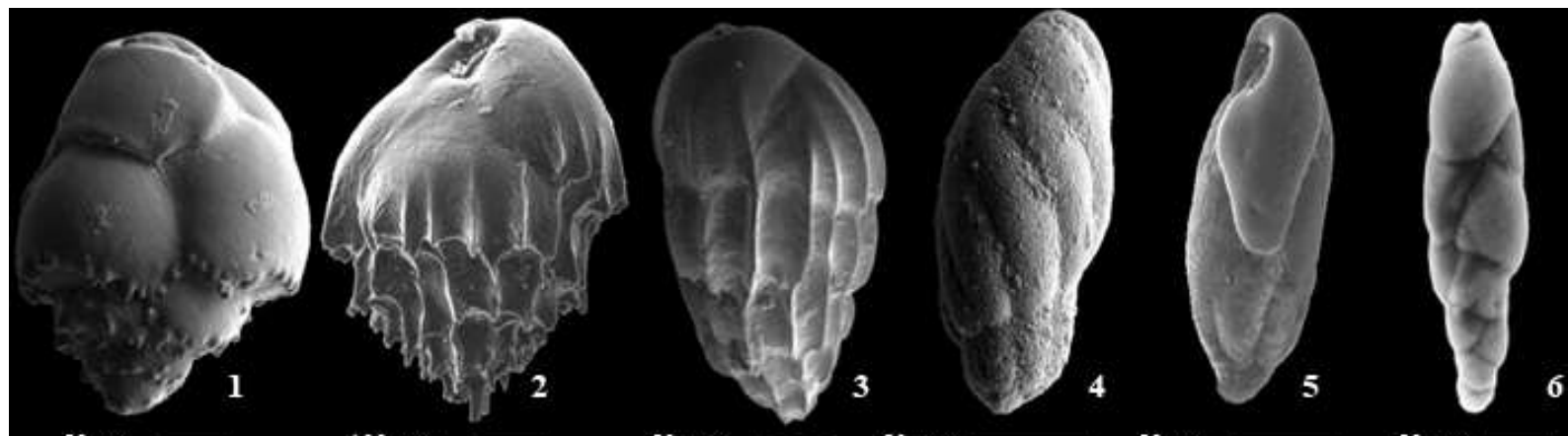

$50 \mu \mathrm{m}$

$100 \mu \mathrm{m}=50 \mu \mathrm{m}$

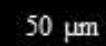

$50 \mu \mathrm{m}$

$50 \mu \mathrm{m}$
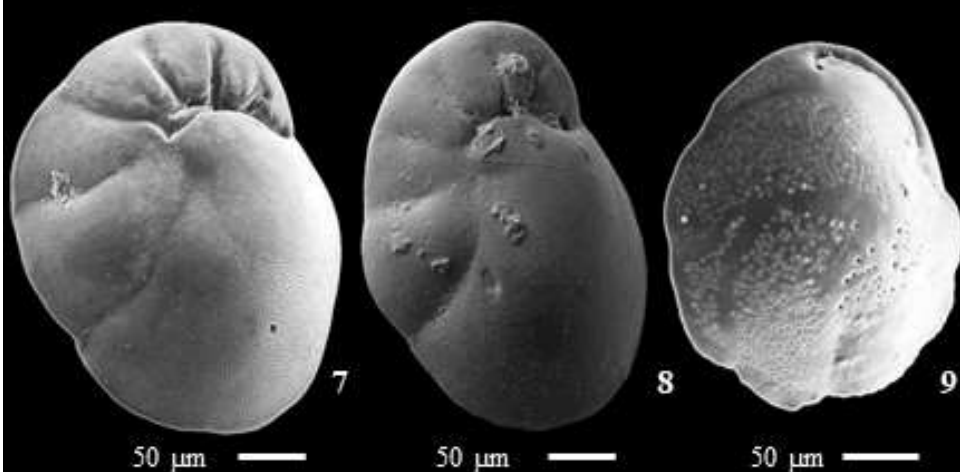

$50 \mu \mathrm{m}=$

$50 \mu \mathrm{m}$
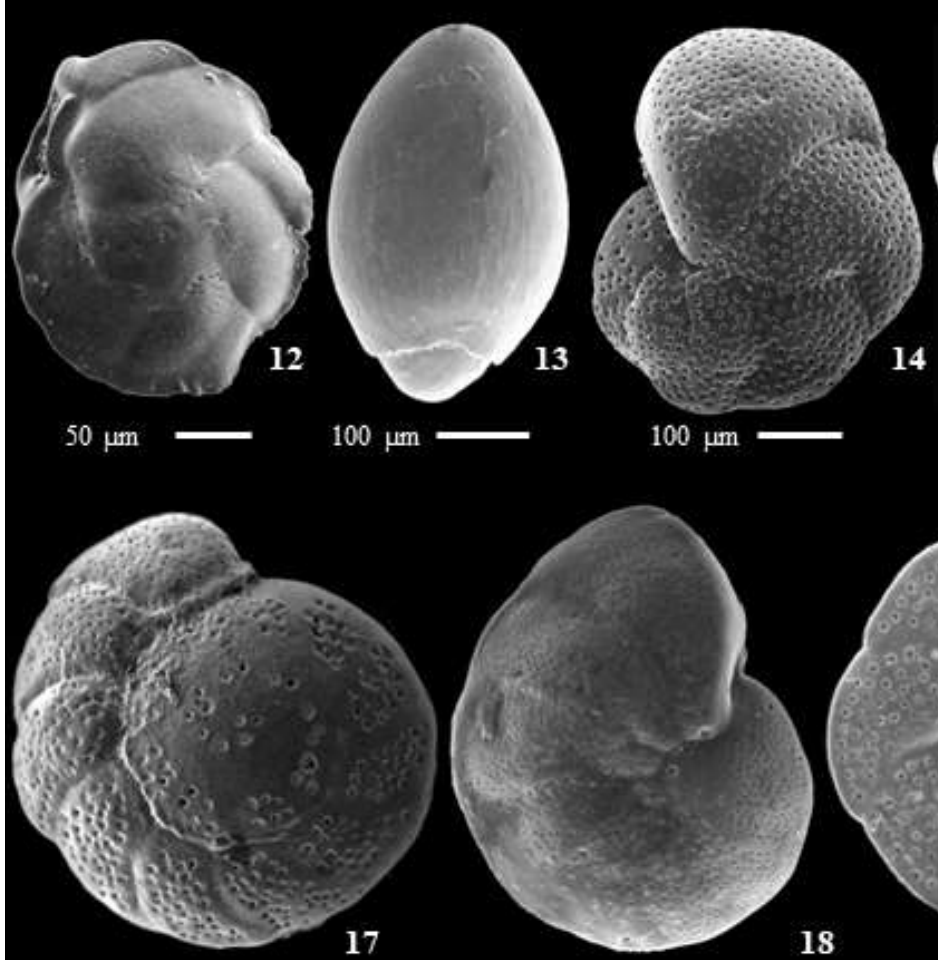

14

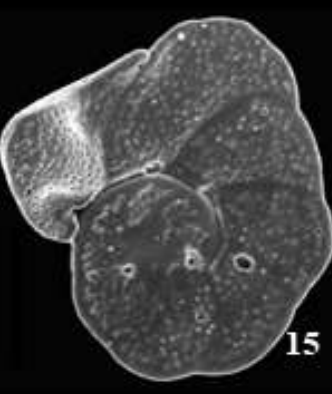

$100 \mu \mathrm{m}$

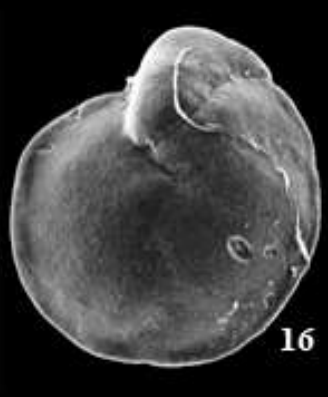

$100 \mu \mathrm{m}$

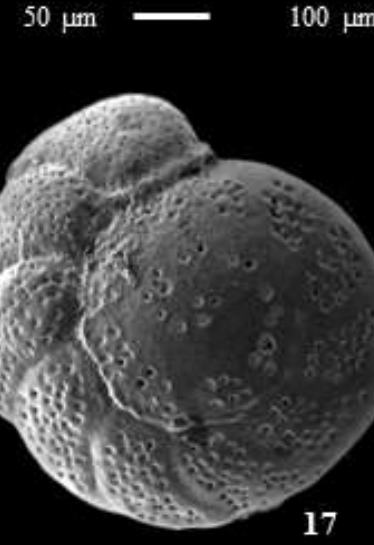

$200 \mu \mathrm{m}$
$100 \mu \mathrm{m}$
18

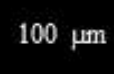

15

.

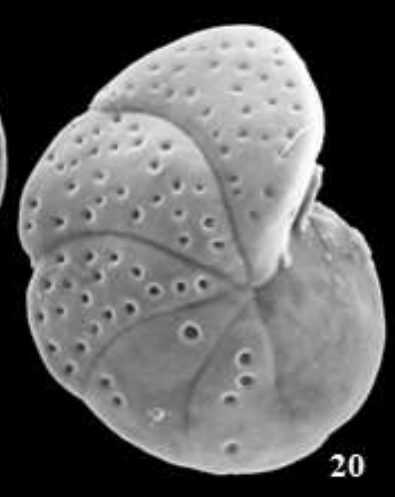

$50 \mu \mathrm{m}$

\section{Plate 10}

Plate 10. 1. Bulimina marginata d'Orbigny, 1826. 2. Bulimina striata d'Orbigny in Guérin-Méneville, 1832; 3. Bulimina truncana Gümbel, 1868; 4-5. Buliminella elegantissima (d'Orbigny, 1839); 6. Buliminella tenuata Cushman, 1927; 7. Cancris auricula (Fichtel and Moll, 1798); 8. Cancris oblongus (Williamson, 1858 ); 9. Cassidulina carinata Silvestri, 1896; 10. Cassidulina laevigata d'Orbigny, 1826; 11-12. Cassidulina teretis Tappan, 1951; 13. Chilostomella ovoidea Reuss, 1850; 1415. Cibicidoides lobatulus (Walker and Jacob, 1878); 16-17. Cibicidoides pachyderma (Rzehak, 1886); 18-19. Cibicidoides pseudoungeriana (Cushman, 1922$) ; 20$. Cibicidoides ungerianus (d'Orbigny, 1846). 


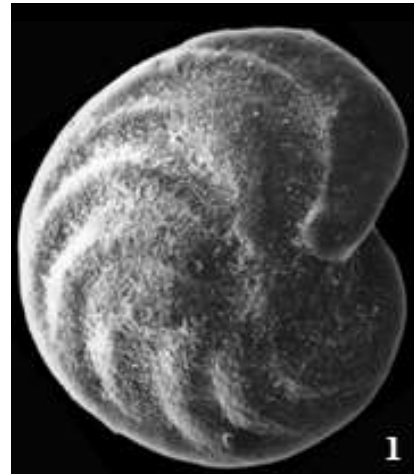

$100 \mu \mathrm{m}$

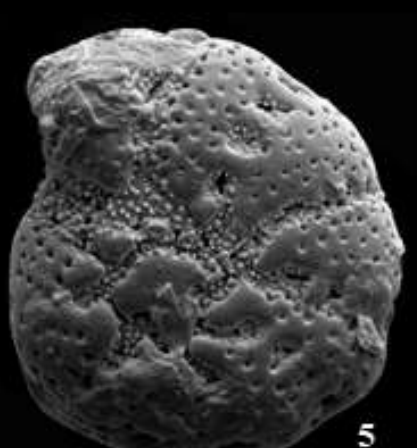

$100 \mu \mathrm{m}$

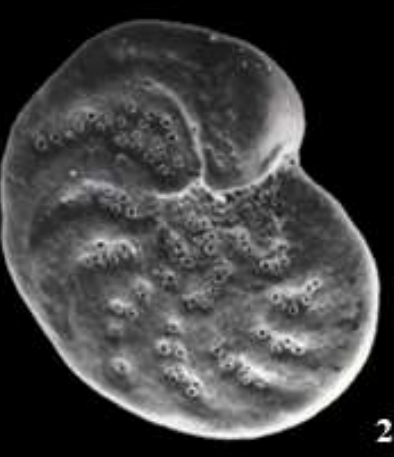

$100 \mu \mathrm{m}$

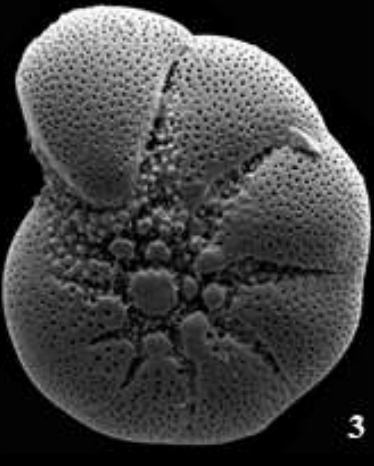

$100 \mu \mathrm{m}$

3

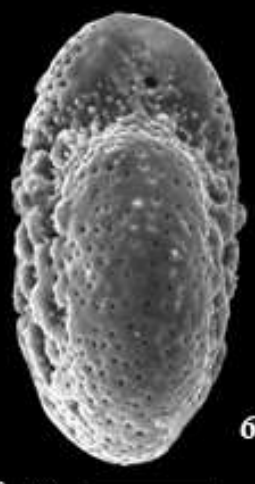

$100 \mu \mathrm{m}$

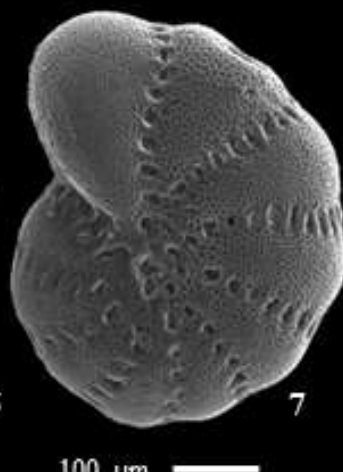

$100 \mu \mathrm{m}$

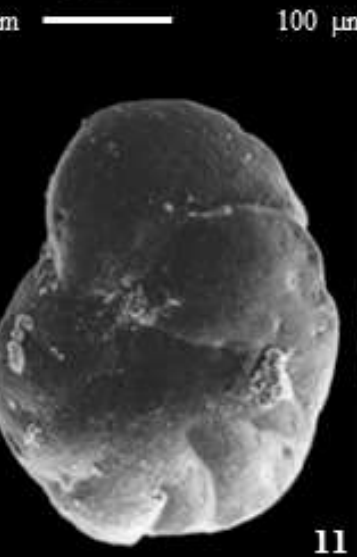

11

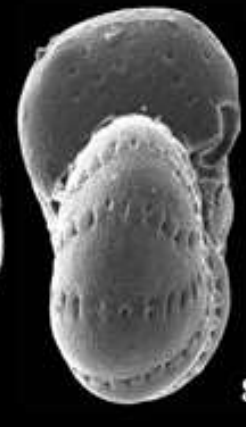

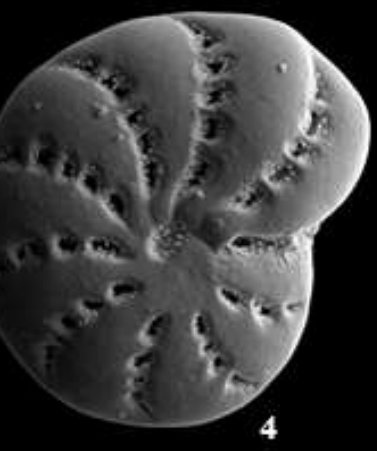

$100 \mu \mathrm{m}$

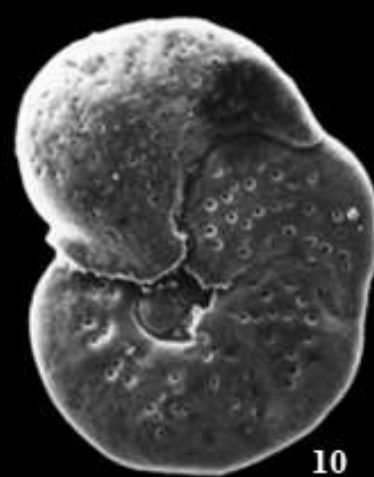

$100 \mu \mathrm{m}$
$100 \mu \mathrm{m}$

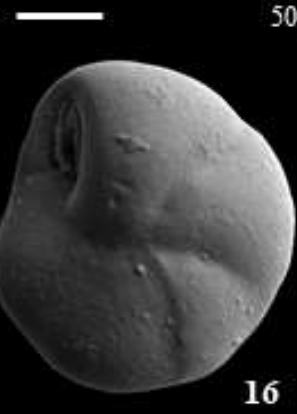

$50 \mu \mathrm{m}$
16

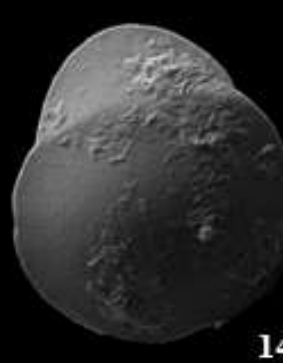

$50 \mu \mathrm{m}$
14

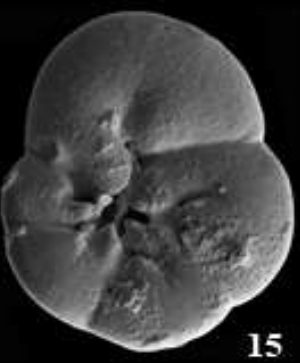

$50 \mu \mathrm{m}$

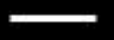

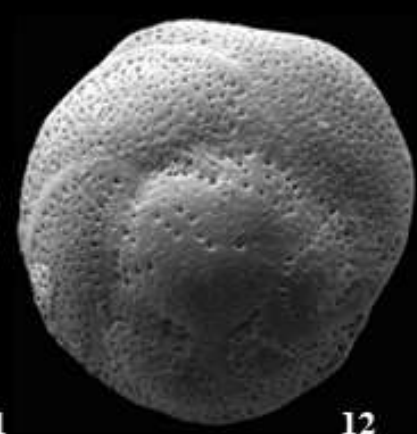

$50 \mu \mathrm{m}$

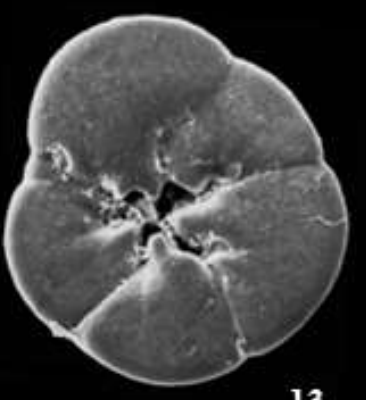

13

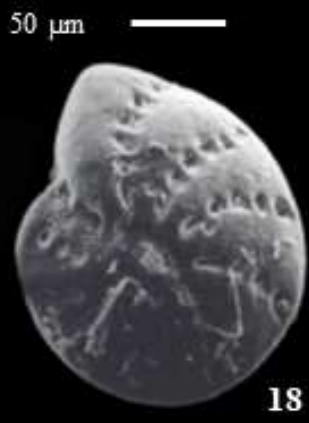

$100 \mu \mathrm{m}$

\section{Plate 11}

Plate 11. 1-2. Cibicidoides wuellerstorfi (Schwager, 1866); 3. Cribroelphidium excavatum (Terquem, 1875); 4. Cribroelphidium gerthi (van Voorthuysen, 1957); 5 6. Cribroelphidium gunteri (Cole, 1931); 7-8. Cribroelphidium poeyanum (d'Orbigny, 1839); 9. Cribroelpbidium williamsoni (Haynes, 1973); 10-11. Discorbinella bertheloti (d'Orbigny, 1839); 12-13. Discorbinella nitida (Williamson, 1858); 14-15. Discorbis parkeri Natland, 1950; 16-17. Eilohedra vitrea (Parker, 1953$) ; 18$. Elphidium advenum (Cushman, 1922). 


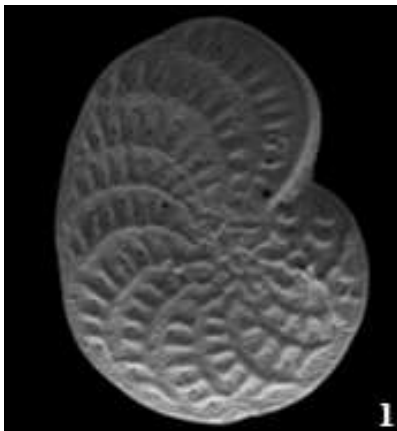

$100 \mu \mathrm{m}$
1 $100 \mu \mathrm{m}$
2

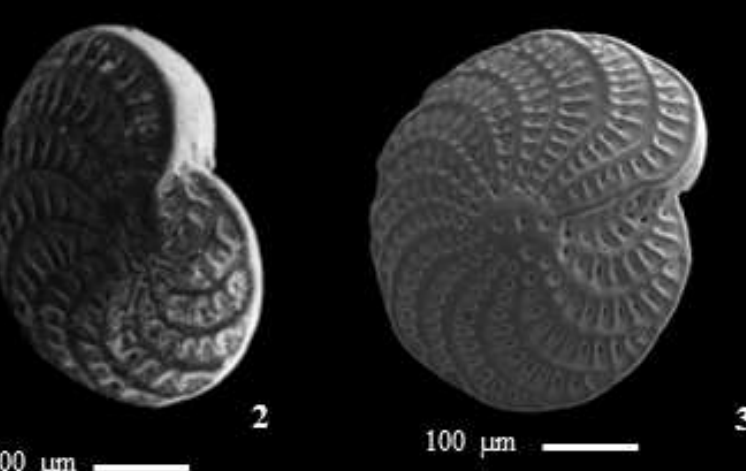

3

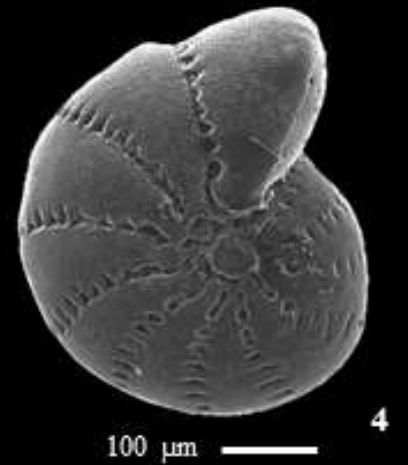

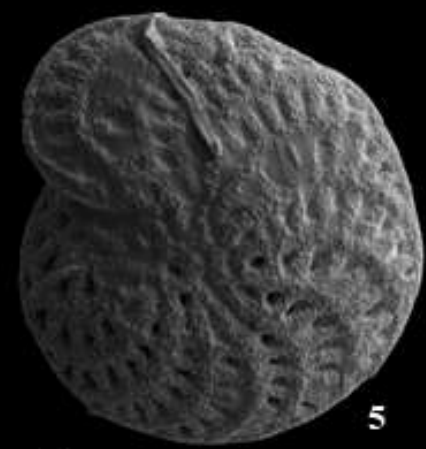

$100 \mu \mathrm{m}$

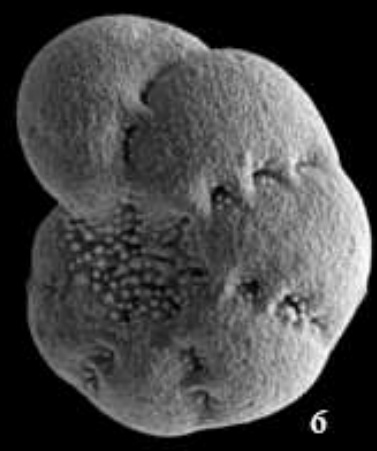

$50 \mu \mathrm{m}$

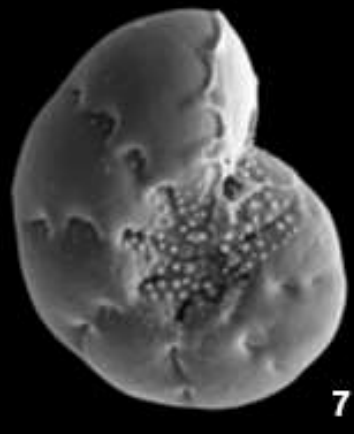

$50 \mu \mathrm{m}$
8

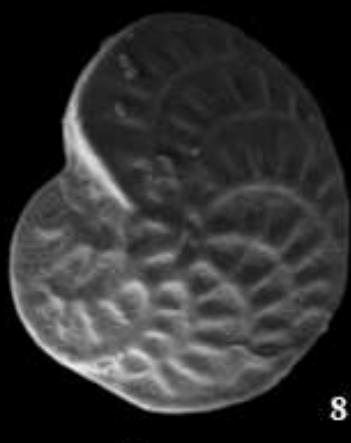

$50 \mu \mathrm{m}$

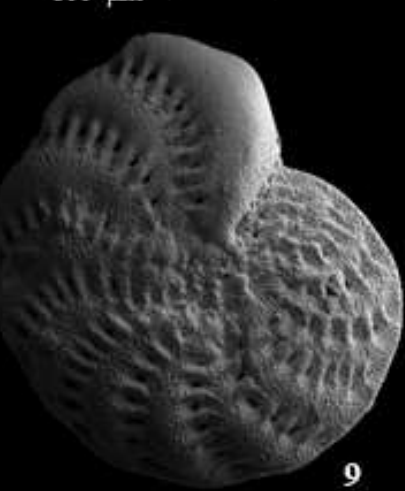

$100 \mu \mathrm{m}$

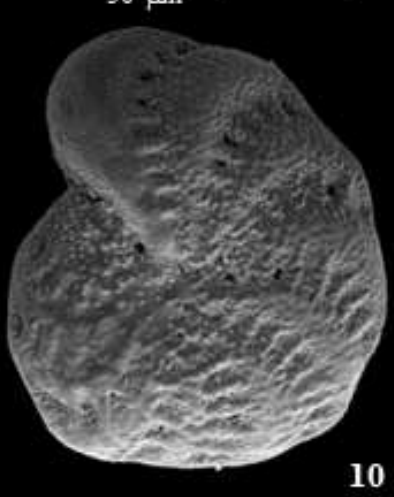

10
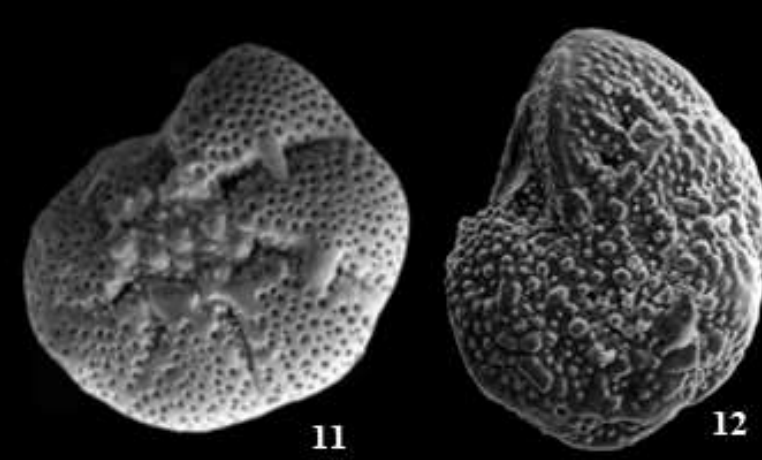

$50 \mu \mathrm{m}$

11

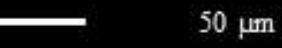

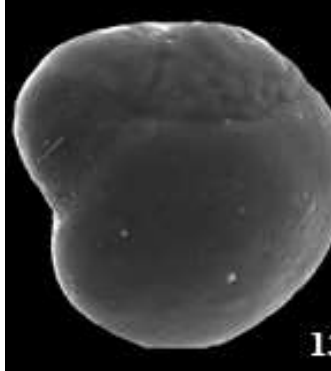

$50 \mu \mathrm{m}$
13

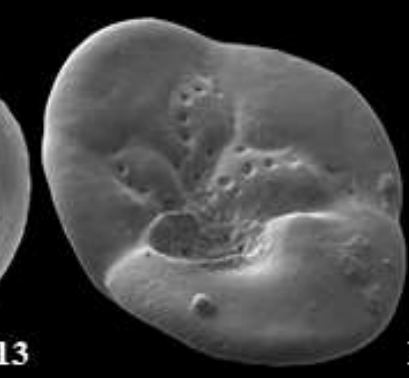

$50 \mu \mathrm{m}$

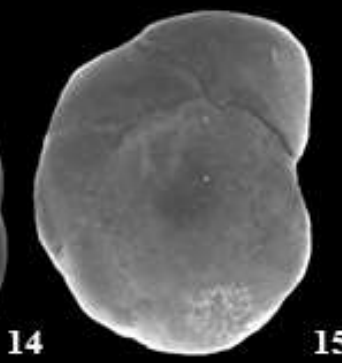

$50 \mu \mathrm{m}$
15

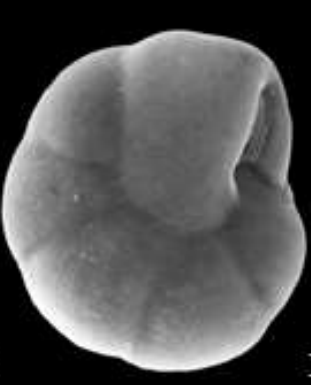

$50 \mu \mathrm{m}$
16

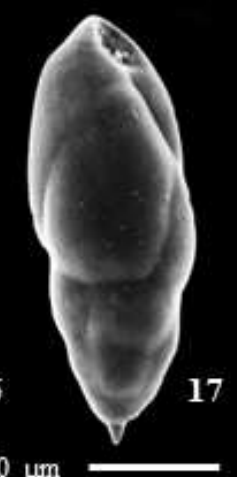

\section{Plate 12}

Plate 12. 1-2. Elphidium complanatum (d'Orbigny, 1839); 3. Elphidium crispum (Linnaeus, 1758); 4. Elphidium discoidale (d'Orbigny, 1839); 5. Elphidium fichtelianum (d'Orbigny, 1846); 6-7. Elphidium sp.; 8. Elphidium macellum (Fichtel and Moll, 1798); 9-10. Elphidium margaritaceum Cushman, $1930 ; 11$. Elphidium oceanense (d'Orbigny in Fornasini, 1904); 12. Elphidium pulvereum Todd, 1958; 13-14. Eoeponidella nanoconica Seiglie, 1965; 15-16. Epistominella exigua (Brady, 1884); 17. Eubuliminella exilis (Brady, 1884). 
Paratrochammina obliqua Brönnimann and Zaninetti, 1984

$$
\text { (Plate 5, Fig. 10) }
$$

Paratrochammina (Lepidoparatrochammina) obliqua Brönnimann and Zaninetti, 1984, pp. 71-72.

Morphological description: The trochospiral test has a dextral coiling. Its contour is oval and slightly lobed. The convexity on the spiral side is low and the concavity on the umbilical side is small; the peripheral margin is rounded. At the umbilical side, the axial depression is open and deep, partially showing the apertures of the preceding chambers; the contour of this depression is in the form of a hexagonal star, with six small incisions in oblique arrangement. The test consists of more than twenty axially compressed chambers arranged in three whorls; the last whorl of the umbilical side has six chambers, vaguely shaped like a kidney, being separated by incisive, radial and oblique sutures. The sutures are slightly different on the spiral side. Each chamber is provided with a simple aperture, in an inter-marginal-axial position. The wall is thin, agglutinated and imperforated. The test is brown. Its diameter measures about $160 \mu \mathrm{m}$.

Ecology and Distribution: It was found in shallow environments of sheltered bays (Brönnimann and Zaninetti, 1984), living (up to $2 \%$ ) in the inner continental shelf in front of the Aveiro Lagoon outflow.

Portatrochammina murrayi Brönnimann and Zaninetti, 1984

(Plate 5, Figs. 13-15)

Portatrochammina murrayi Brönnimann and Zaninetti, 1984, pp. $72-74$, pl. 5, figs. 7, 12-15.

Morphological description: Trochospiral test, with four chambers, on the last whorl, separated by depressed sutures. On the umbilical side, the aperture opens through a sort of "flap" of the last chamber covering most of the axial depression; only small portions of the anterior flaps are visible. The aperture is of Paratrochammina type, becoming this taxonomic characteristic more important than the presence of the flaps. The lateral extensions of these flaps are defined by small recesses. The wall is finely agglutinated. Its diameter measures about $100 \mu \mathrm{m}$.

Ecology and Distribution: It occurs at England coastal areas (Brönnimann and Whittaker, 1990). Their presence on the Portuguese continental shelf was reported by Levy et al. (1995). It was found living (up to $5 \%$ ) in the mid shelf in front of the Aveiro Lagoon outflow but is rare.

\section{Genus Remaneica Rhumbler 1938}

Remaneica anglica Brönnimann and Whittaker, 1990

(Plate 5, Fig. 16)

Remaneica anglica Brönnimann and Whittaker, 1990, pp. 123124, pl. 6, figs. 5-8.
RESEARCH PAPER

Morphological description: The compressed test has a relatively tight, ladder-shaped dextral winding. Its spiral side has low convexity and the umbilical side has small concavity. Its margin is surrounded by a peripheral border. The rim constitutes a granular and flexible surface when the test is wet. The test contour is oval. The axial depression on the ventral face is starched having six slightly curved arms. The umbilical lobes are axially rounded. The chambers, 15 or 16 in number (including a large ellipsoid proloculus), are strongly axially compressed; they are arranged in two whorls, the last one with six chambers. On the spiral side, the initial chambers are equidimensional, becoming gradually elongated. The sutures are well defined on both sides of the test. Each chamber has two apertures: a simple, primary interiomarginal or slightly areal aperture, with an arch form, outlined by a lip, and a secondary simple one. The agglutinated and imperforate wall is composed on the spiral side by a mosaic of relatively large sediment grains which are more regular on the umbilical side.

Ecology and Distribution: It occurs in the Plymouth region on the coasts of England (Brönnimann and Whittaker, 1990). It was found living (up to $5 \%$ ) on the gravely deposits of Aveiro mid continental shelf where it is uncommon.

\section{Remaneica belgolandica Rhumbler, 1938}

$$
\text { (Plate 6, Fig. 1) }
$$

Remaneica belgolandica Rhumbler, 1938, p. 195, figs. 38-42. Trochammina (Remaneica) belgolandica (Rhumbler); Höglund, 1947, pp. 212-213, pl. 16, fig. 3; p. 209, figs. 191-192.

Remaneica helgolandica Rhumbler; Levy et al.,1974, p. 128, pl. 2, figs. 1-2.

Remaneica belgolandica Rhumbler; Brönnimann and Whittaker, 1990, pp. 121-123, pl. 6, figs. 1-4; pl. 8, fig. 8.

Morphological description: The compressed and very thin test is attached to the substrate by the involute side, which is flattened or concave. Its evolute face has the form of a little dome. The sinistral coiling, with a ladder form, is not too tight. The test consists of 23 chambers, including a large and ellipsoid proloculus, arranged in three whorls; the latter has 9-11 chambers, half-moon shaped on both sides of the test. The axial depression of the ventral face is wide and shows the secondary apertures of the previous whorls. The compressed peripheral margin is not carinate. The umbilical/spiral contour of the test is subcircular and slightly lobed. The umbilical wall of the chambers invaginates along the radial sutures. There are two types of apertures: the simple, primary aperture consists of a slit located along the inner suture of the last chamber on the involute side and the secondary aperture is a rounded arch in an axial-sutural position. The invaginated margin of the chambers gives rise to series of pillars (which can be observed, externally, as sutural folds). The agglutinated, thin and imperforate wall is brown. 
Ecology and Distribution: It is present at the coasts of England (Brönnimann and Whittaker, 1990) and in the estuarine biotopes of Northern of France (Pujos, 1976). It is common in the study area, where it was found living in the external sector of the Aveiro Lagoon and in the nearby inner continental shelf. Its relative abundance was higher in the lagoon inlet (up to $11 \%$ ).

Genus Remaneicella Brönnimann, Zaninetti and Whittaker, 1983

$$
\text { Remaneicella gonzalezi (Seiglie, 1965) }
$$

(Plate 6, Fig. 2)

Remaneica gonzalezi Seiglie, 1965, p. 500, pl. 1, figs. 6-8. Remaneicella gonzalezi (Seiglie); Brönnimann and Whittaker, 1990, pp. 124-125, pl. 5, figs. 13-15.

Morphological description: The test is depressed, strongly arched and is evolute on the spiral side and has the involute face on the umbilical side. It consists of numerous chambers, strongly compressed, arranged in about three whorls; the last whorl has six to seven chambers. The test exhibits a dextral, ladder-shaped coiling. The umbilical side shows different types of secondary septa spaced apart from each other. The initial chambers are equidimensional and half-moon shaped. On the spiral side, the chambers are well recognizable. The sutures of the dorsal surface are difficult to distinguish except when the test is moistened; the sutures on the ventral side, are also not clearly defined, due to the folds of the wall. The brown-colored wall is pseudochitinous, thin, flexible, with little or no agglutinated material. The aperture is located at the edge of the umbilicus. The umbilical/spiral diameter measures about $300 \mu \mathrm{m}$.

Ecology and Distribution: It occurs at the coasts of England (Brönnimann and Whittaker, 1990) and is common in the study area. It was found living in the Aveiro Lagoon inlet (up to $5 \%$ ), where its percentage was relatively higher, and on the gravely deposits of the Aveiro mid continental shelf.

\section{Rotaliammina adaperta (Rhumbler, 1938)}

(Plate 6, Fig. 9)

Trochammina squamata Jones and Parker var. adaperta Rhumbler 1938, p. 184, figs. 21-26.

Trochammina squamata Jones and Parker var. adaperta Rhumbler, 1938; Levy et al., 1974, p. 130, pl. 1, fig. 8.

Trochammina squamata ones and Parker var. adaperta Rhumbler, 1938; Alve and Nagy, 1986, p. 282, pl. 3, figs. 15-16.

Morphological description: It has six to nine chambers, in the last whorl. The chambers of the ventral side are kidney shaped with strong recesses centered on its inner margin (considering the direction of growth).

Ecology and Distribution: Uncommon. It was found living in the external sector of Aveiro Lagoon and in the nearby continental shelf where it reached higher relative abundance on the gravely deposits (up to $7.5 \%$ ).

Rotaliammina concava (Seiglie, 1965)

(Plate 6, Figs. 10-11)

Tiphotrocha concava Seiglie, 1965, pp. 500-501.

Morphological description: Test small, attached, dome-shaped, compressed trochospiral, with rounded periphery. Chambers arranged in three or four whorls; the ventral side is concave, where the chambers of the last whorl have lobes projecting into the umbilicus. Sutures are slightly or not depressed. Wall pseudo-chitinous, thin, flexible, with scarce agglutinated material and brown to reddish brown color. Apertures in the umbilical ends of the ventral lobes of the chambers. Diameter of about $160 \mu \mathrm{m}$.

Ecology and Distribution: It is a frequent species in the external sector of the Aveiro lagoon. It reaches the highest relative abundance in the lagoon inlet (up to $62 \%$ ).

Rotaliammina petaloidea Brönnimann, Zaninetti and Whittaker, 1983

(Plate 6, Fig. 12)

Rotaliammina petaloidea Brönnimann, Zaninetti and Whittaker, 1983, pp. 213-214, pl. 1, figs. 5, 7-11.

Morphological description: The trochospiral test with dextral coiling is axially strongly compressed. It is surrounded by a thin and shiny rim (flexible in water). Its outer umbilical / spiral outline has circular or oval shape. The spiral side is convex, with pointed apex and concave umbilical face. It is difficult to determine the total number of chambers on the spiral side, since the sutures are slightly different. The ventral face has five chambers in an asymmetrical petaloid arrangement. The simple and interiomarginal aperture is located at the axial termination of a small central rod. The anterior chamber aperture surrounds the umbilical depression. The agglutinated and imperforate wall is brown, being darker at the apex of the whorl. The test diameter measures about $160 \mu \mathrm{m}$.

Ecology and Distribution: It was found living on gravely deposits of the Aveiro inner to mid continental shelf (up to 3\%)

\section{Rotaliammina sigmoidea Wells 1985}

(Plate 6, Fig. 13)

Rotaliammina sigmoidea Wells 1985, p. 590, 592.

Morphological description: The test is small, compressed, trochospiral, with a rounded periphery. In ventral side, the 10-11 chambers of the last whorl are narrow, elongated and retroversed with small projections into the umbilicus. 

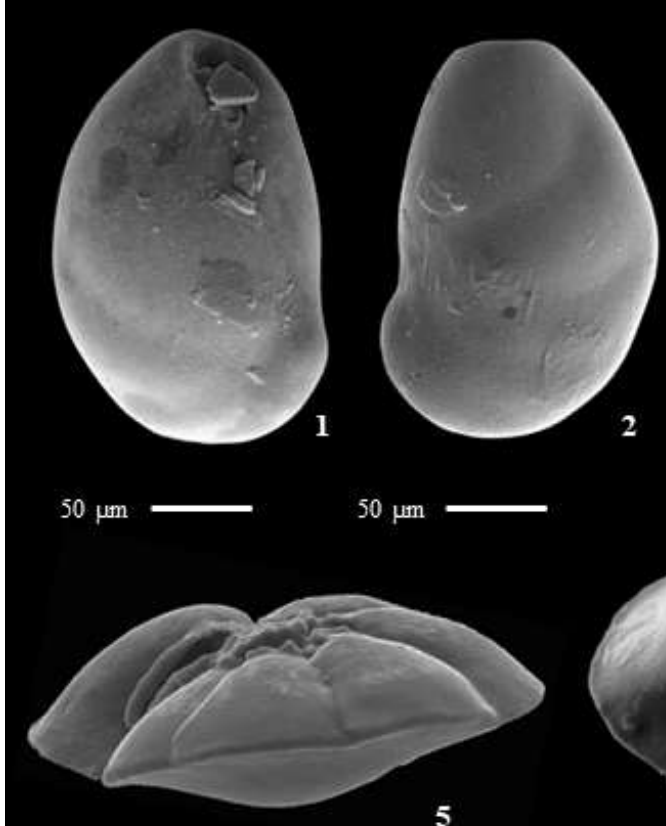

$50 \mu \mathrm{m}$

5

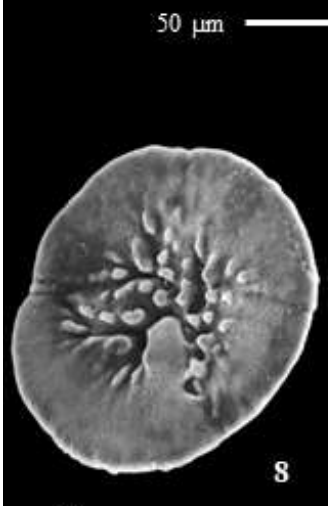

$50 \mu \mathrm{m}$

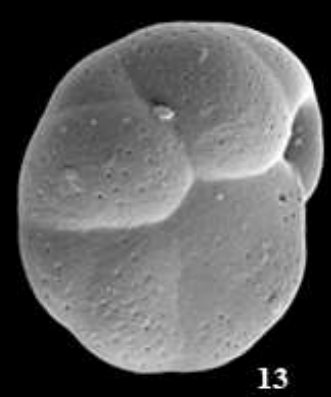

$50 \mu \mathrm{m}$
13

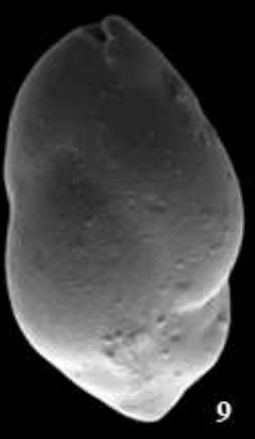

9

$100 \mu \mathrm{m}$

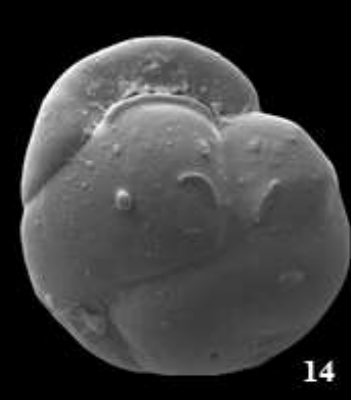

$50 \mu \mathrm{m}$
2

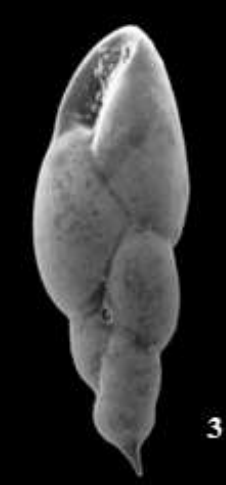

3

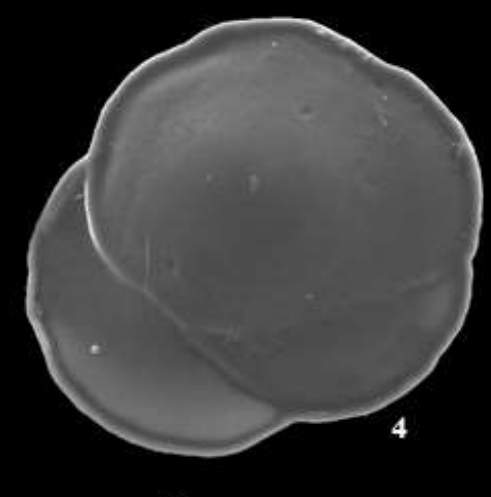

$50 \mu \mathrm{m}$

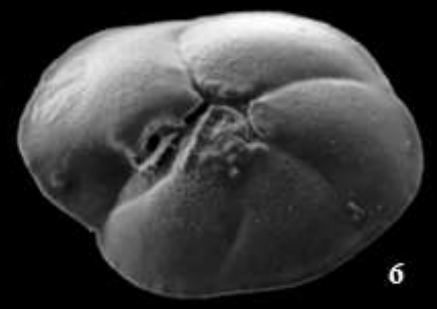

$50 \mu \mathrm{m}$

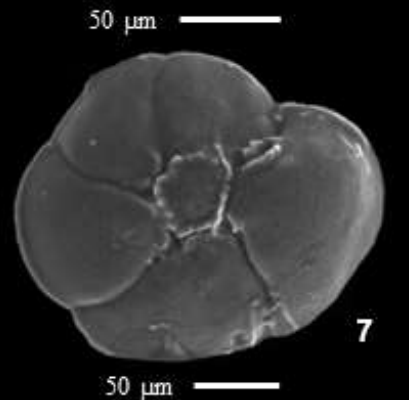

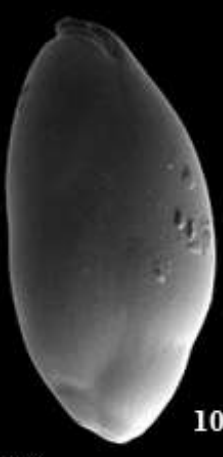

10

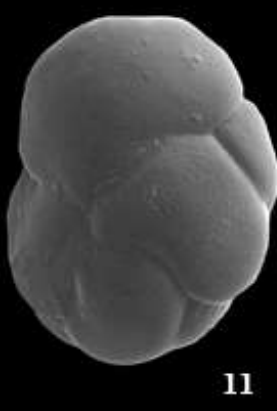

$50 \mu \mathrm{m}$

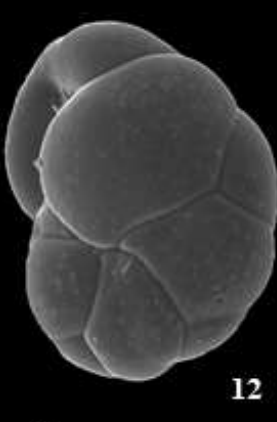

$50 \mu \mathrm{m}$

12

14

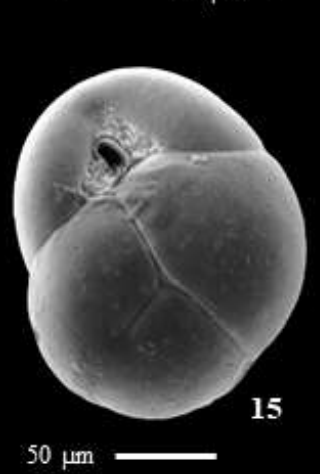

$50 \mu \mathrm{m}$

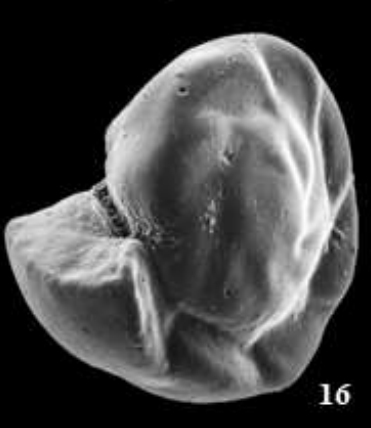

$100 \mu \mathrm{m}$

\section{Plate 13}

Plate 13. 1-2. Evolvocassidulina bradyi (Norman, 1881); 3. Fursenkoina complanata (Egger, 1893); 4-7. Gavelinopsis praegeri (Heron-Allen and Earland, 1913); 8. Glabratella millettii (Wright, 1911); 9. Globobulimina affinis (d'Orbigny, 1839); 10. Globobulimina auriculata (Bailey, 1894); 11-12. Globocassidulina crassa subsp. rossensis Kennett, 1967; 13. Globocassidulina crassa (d'Orbigny, 1839); 14. Globocassidulina minuta (Cushman, 1933); 15. Globocassidulina subglobosa (Brady, 1881); 16. Gyroidina altiformis Stewart and Stewart, 1930. 


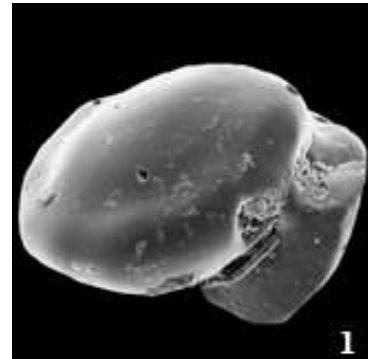

1

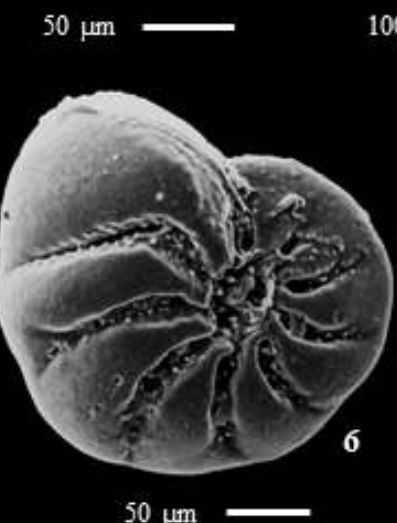

$100 \mu \mathrm{m}$

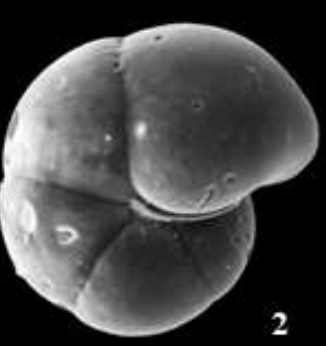

2

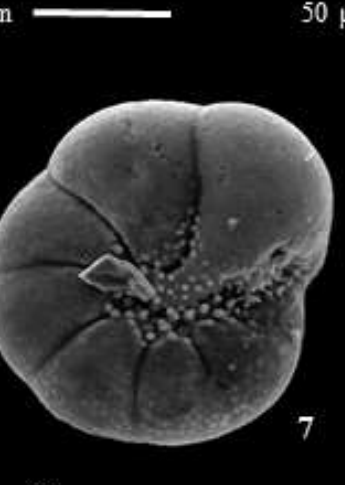

$50 \mu \mathrm{m}$

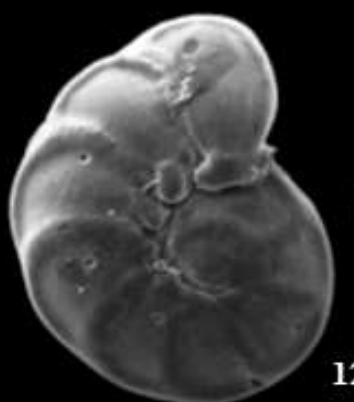

$100 \mu \mathrm{m}$

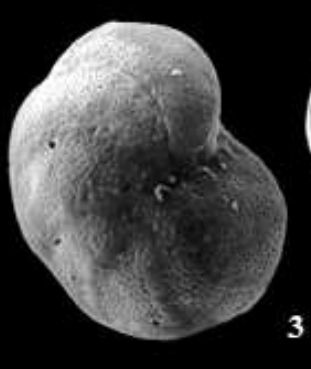

$50 \mu \mathrm{m}$

3

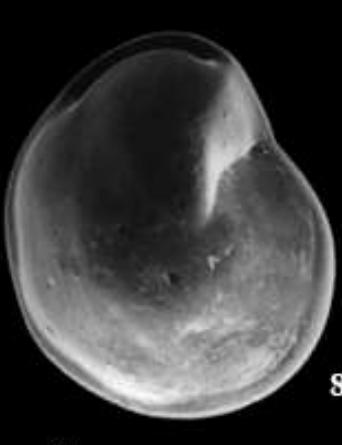

$50 \mu \mathrm{m}$

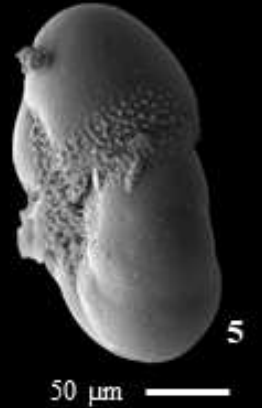

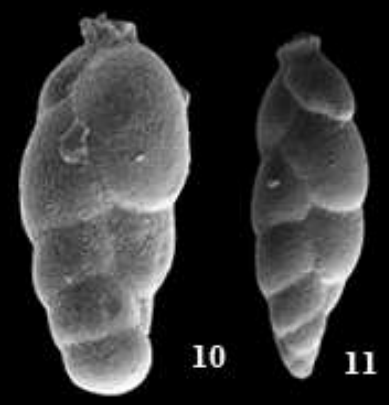

$50 \mu \mathrm{m}$
$50 \mu \mathrm{m}$

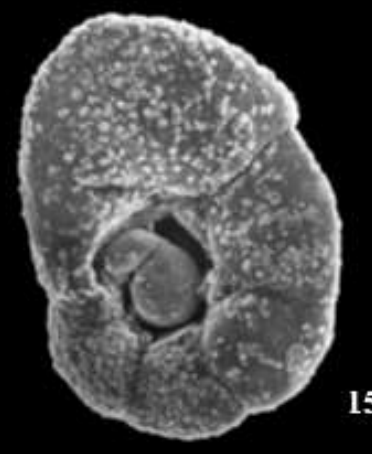

$50 \mu \mathrm{m}$
15

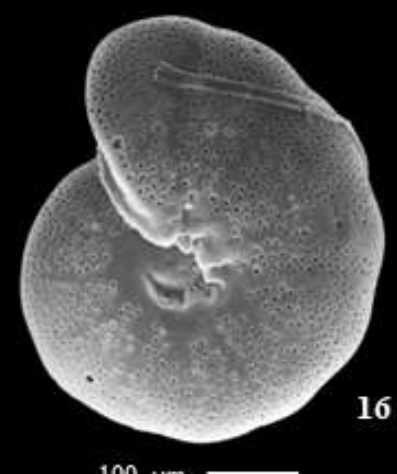

$100 \mu \mathrm{m}$

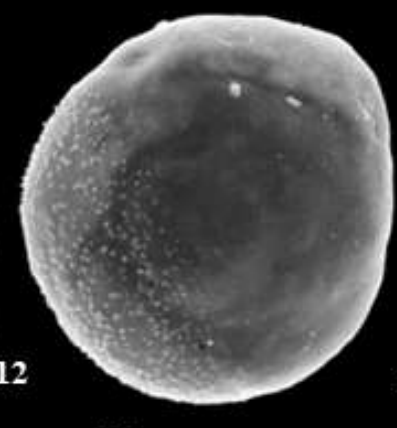

$100 \mu \mathrm{m}$

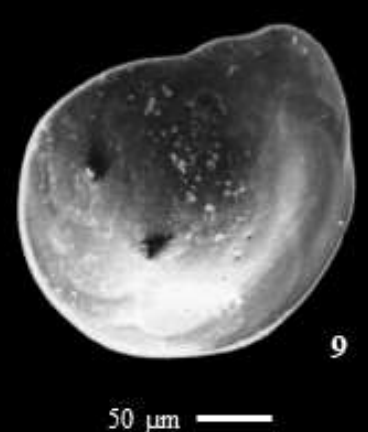

13

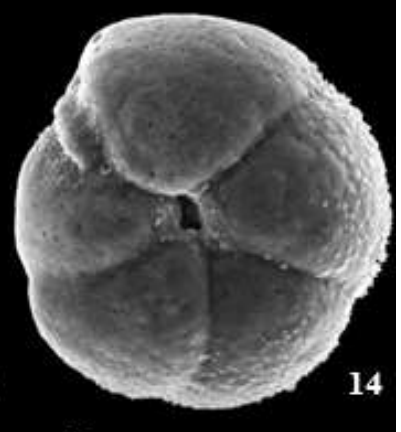

$100 \mu \mathrm{m}$

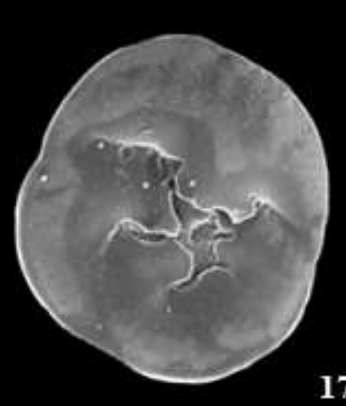

$100 \mu \mathrm{m}$

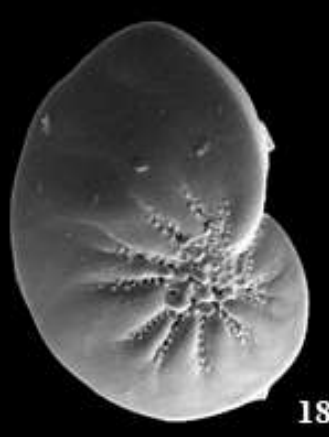

17

$100 \mu \mathrm{m}$

18

\section{Plate 14}

Plate 14. 1. Gyroidina orbicularis d'Orbigny in Parker, Jones and Brady, 1865; 2. Gyroidina umbonata (Silvestri, 1898); 3-4. Hanzawaia nitidula (Bandy, 1953); 5-6. Haynesina germanica (Ehrenberg, 1840); 7. Helenina anderseni (Warren, 1957); 8-9. Hoeglundina elegans (d'Orbigny, 1826); 10-11. Hopkinsina atlantica Cushman, 1944; 12. Hyalinea balthica (Schröter in Gmelin, 1791); 13-14. Ioanella tumidula (Brady, 1884); 15. Lamarckina haliotidea (Heron-Allen and Earland, 1911); 16. Melonis barleeanus (Williamson, 1858); 17. Neoconorbina terquemi (Rzehak, 1888); 18. Nonion fabum (Fichtel and Moll, 1798). 


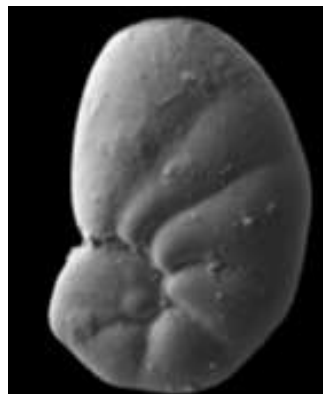

$100 \mu \mathrm{m}$

$\mathbf{l}$

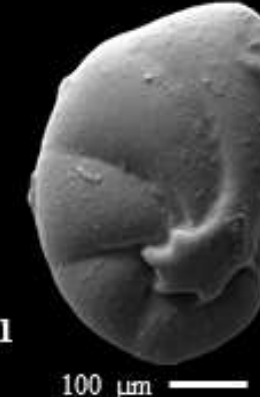

2

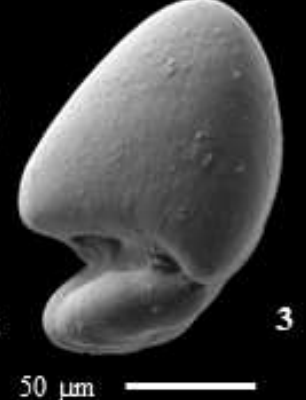

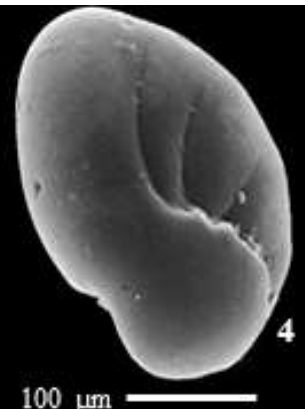

$100 \mu \mathrm{m}$

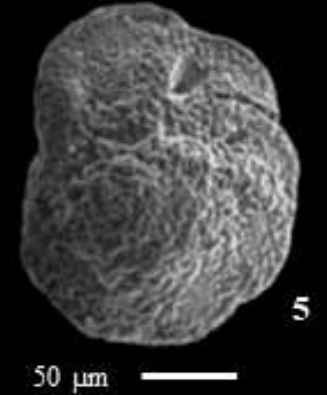

\section{5}

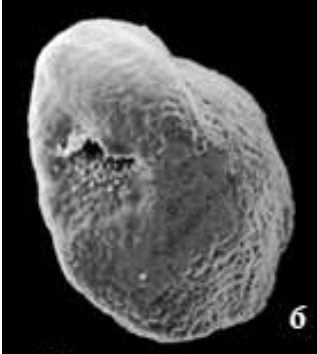

$50 \mu \mathrm{m}$
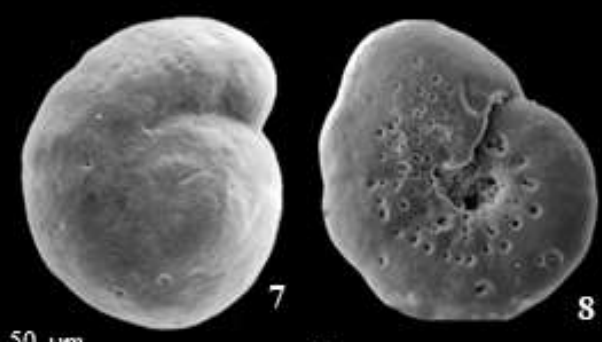

$50 \mu \mathrm{m}$

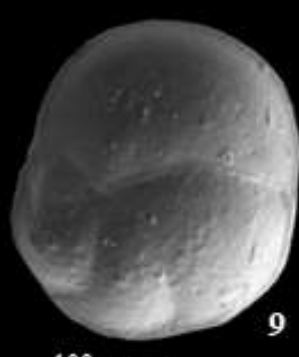

$100 \mu \mathrm{m}$
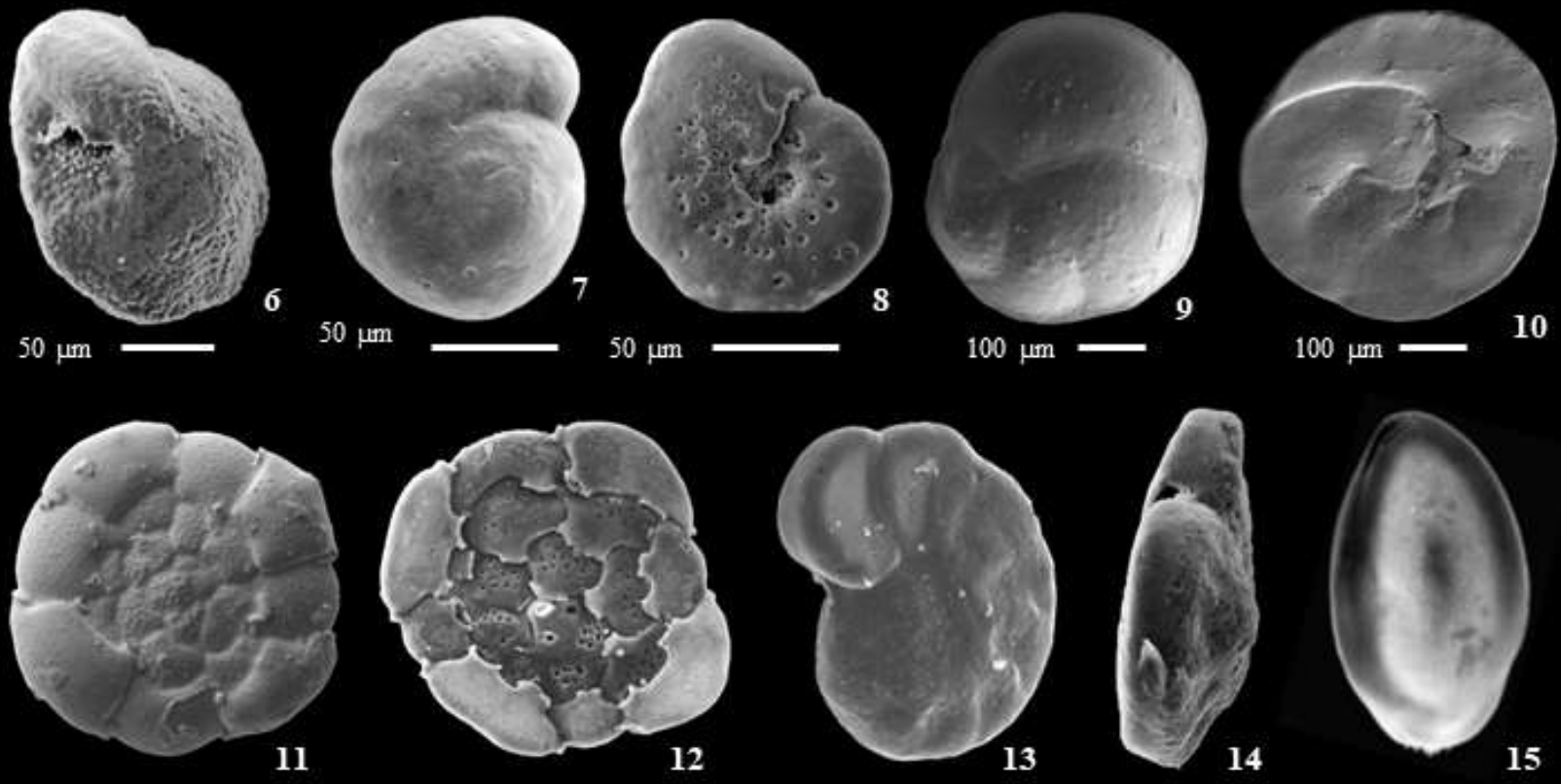

$50 \mu \mathrm{m}$

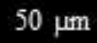

$50 \mu \mathrm{m}$

$50 \mu \mathrm{m}$
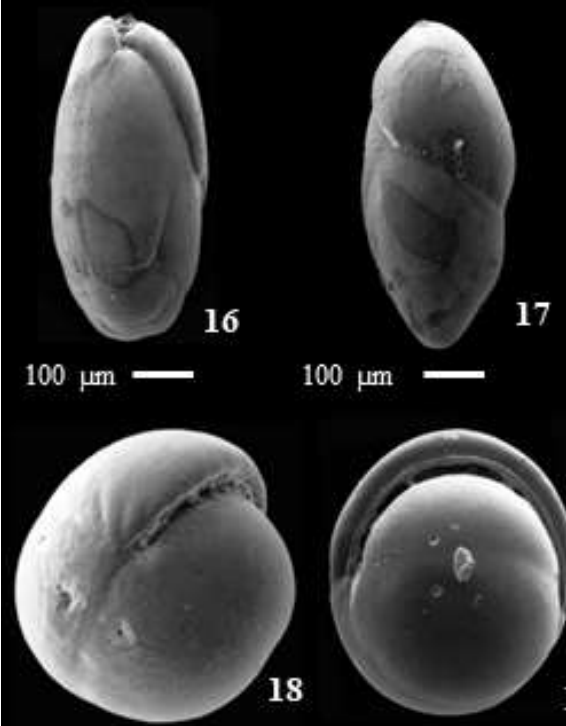

$100 \mu \mathrm{m}$

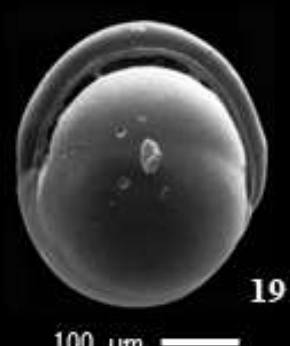

$100 \mu \mathrm{m}$

$100 \mu \mathrm{m}$
19

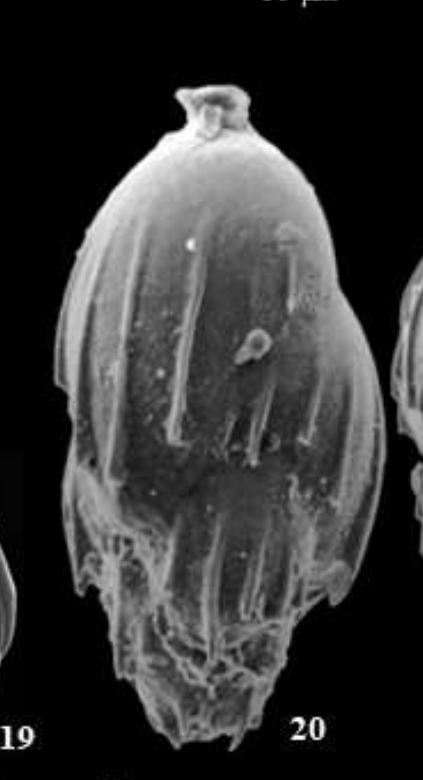

$50 \mu \mathrm{m}$

\section{Plate 15}

Plate 15. 1-2. Nonionella stella Cushman and Moyer, 1930; 3-4. Nonionoides turgidus (Williamson, 1858); 5-6. Oridorsalis umbonatus (Reuss, 1851); 7-8, Paumotua terebra (Cushman, 1930); 9-10. Planodiscorbis rarescens (Brady, 1884); 11-12. Planorbulina mediterranensis d'Orbigny, 1826; 13-14. Planulina ariminensis d'Orbigny, 1826; 15. Praeglobobulimina spinescens (Brady, 1884); 16-17. Protoglobobulimina pupoides (d'Orbigny, 1846); 18-19. Pullenia bulloides (d'Orbigny, 1846); 20-22. Rectuvigerina phlegeri Le Calvez, 1959. 

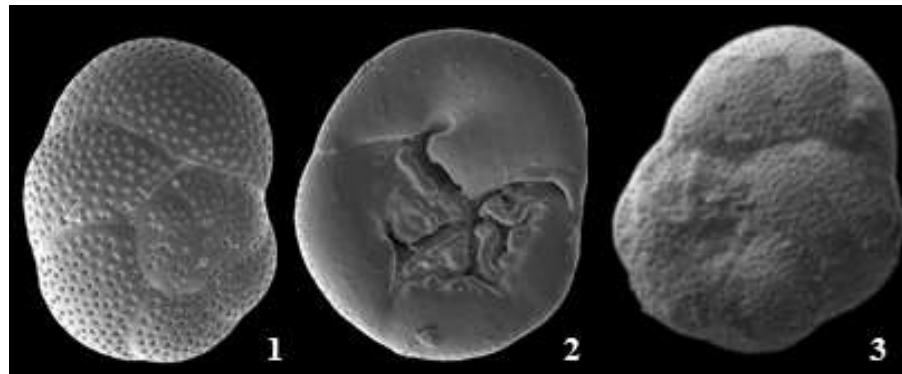

3

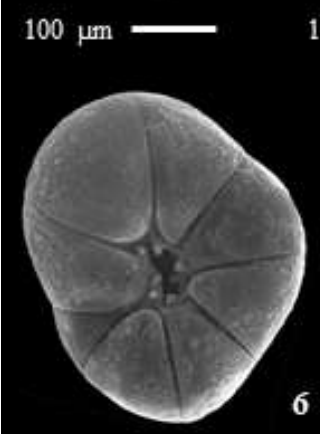

$100 \mu \mathrm{m}$

$50 \mu \mathrm{m}$
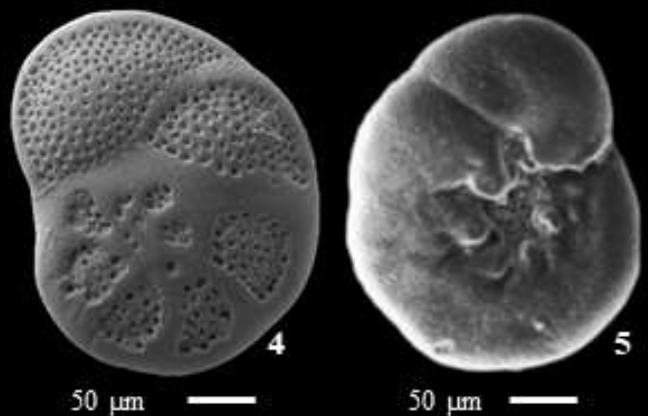

$100 \mu \mathrm{m}$
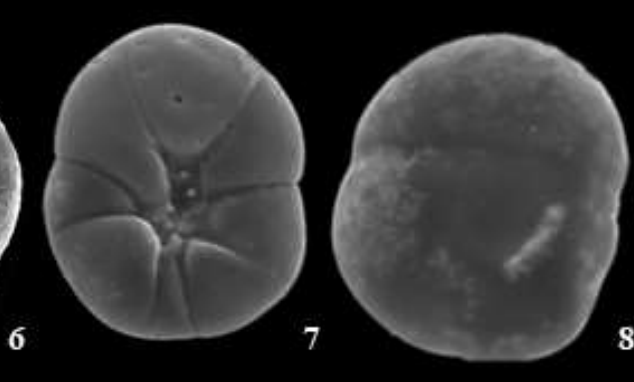

$50 \mu \mathrm{m}$

$50 \mu \mathrm{m}$

5
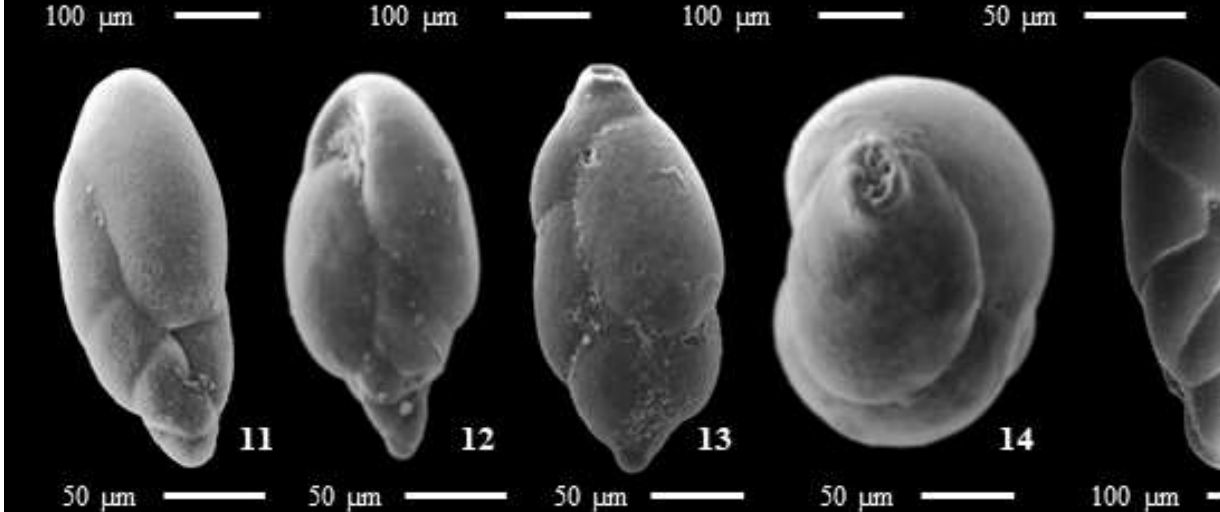

9

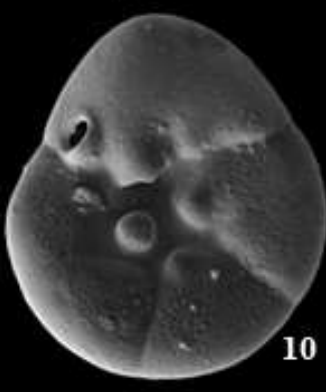

$50 \mu \mathrm{m}$
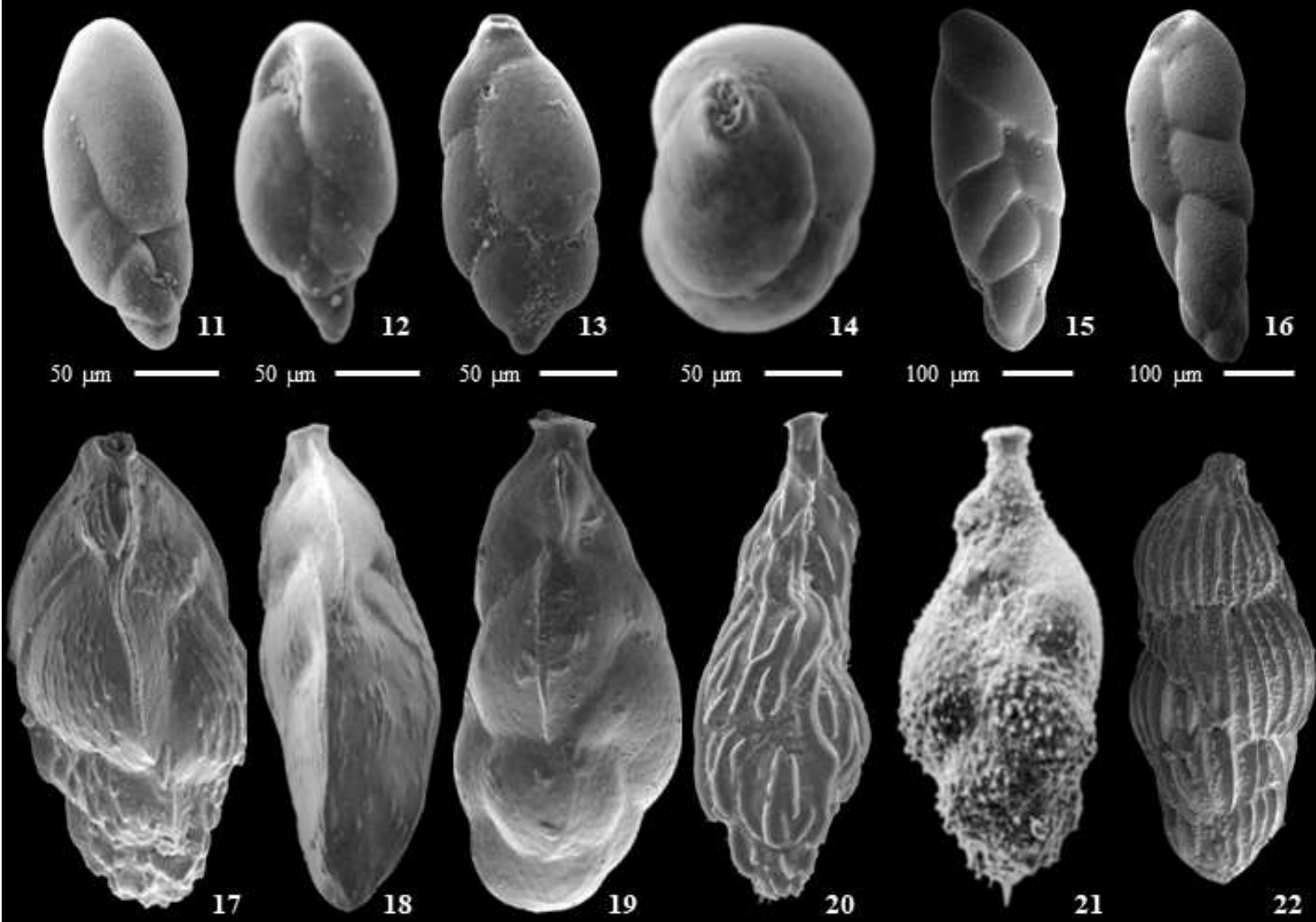

$50 \mu \mathrm{m}$

$50 \mu \mathrm{m}$

$100 \mu \mathrm{m}$

$100 \mu \mathrm{m}$

$50 \mu \mathrm{m}$

$20 \mu \mathrm{m}$

Plate 16

Plate 16. 1-2. Rosalina bradyi (Cushman, 1915); 3. Rosalina obtusa d'Orbigny, 1846; 4-5. Rosalina macropora (Hofker, 1951); 6-8. Rotaliella chasteri (HeronAllen and Earland, 1913); 9-10. Rotorbis auberii (d'Orbigny, 1839); 11-12. Stainfortbia ferlingi Knudsen and Seidenkrantz, 1994; 13-14. Stainforthia fusiformis (Williamson, 1848); 15-16. Stainfortbia loeblichi (Feyling-Hanssen, 1954); 17. Trifarina angulosa (Williamson, 1858); 18. Trifarina bradyi Cushman, $1923 ; 19$.

Trifarina fornasinii (Selli, 1948); 20. Trifarina occidentalis (Cushman, 1923); 21. Uvigerina auberiana d'Orbigny, 1839; 22. Uvigerina peregrina Cushman, 1923. 
Sutures are slightly or not depressed. The wall is rough and bonded with fine sedimentary material and has brown to reddish brown color. Apertures in the ventral ends of the chambers. Diameter of about $140 \mu \mathrm{m}$.

Ecology and Distribution: Rare; it was found living in the Aveiro inlet (up to $1 \%$ ).

\section{Rotaliammina siphonata (Seiglie, 1965)}

Polysiphotrocha siphonata Seiglie 1965, p. 500, pl. 1, fig. 9, a-c; pl. 2, figs. 1-6, 9, a-c.

Rotaliammina siphonata (Seiglie); Brönnimann, Zaninetti and Whittaker, 1983, p. 213, pl. 2-3.

Morphological description: The test is small, evolute on the spiral side, and involute, on the umbilical face. The numerous and heavily compressed chambers are arranged in several whorls ( 3 to 5.5); the last one has 6 to 8 chambers (the number of chambers of the last whorl is smaller in larger specimens). The chambers are petaloid-shaped, with projections identical to siphons around the umbilicus. The wall is brown or reddish-brown, pseudo-chitinous, thin and flexible, with little or no agglutinated material. The apertures are at the end of each projection identical to a siphon.

Ecology and Distribution: It was found living in the external sector of Aveiro Lagoon and in the nearby mid continental shelf (up to $5 \%$ ).

\section{Discussion}

The results of CA and PCA scores for both LA and TA suggest a relationship of the species distribution with depth. This relationship is clearer at the Aveiro continental shelf and upper slope for TA that were analyzed in a larger number of samples than the living ones. In the study area, the shallower stations (depth $<10 \mathrm{~m}$ ) are located within the Aveiro Lagoon. The deeper areas in the Ria de Aveiro are located in the lagoon inlet where depths reach $30 \mathrm{~m}$; this depth is similar to that found in the transition between the inner and middle continental shelf. According to the results presented in Figures 3 and 4 for LA, most of the samples located in the Barra de Aveiro (identified with $\mathrm{E}$ and EMERA), have small relationship with depth, since this area reaches about $30 \mathrm{~m}$ deep and is more influenced by hydrodynamic and marine conditions than the central and internal lagoonal areas. The lagoon inlet zone is affected by tidal currents velocities that can be stronger than $2 \mathrm{~m} / \mathrm{s}$ (Vaz et al., 2009).

In the plot of the PCA scores based on TA, samples of the Barra de Aveiro (identified with E and EMERA), are combined with other lagoonal sites but separated from the oceanic sites (samples 8033 to 8880 and series A 1-2 to B44 ), which reveals a greater contrast between more and less stable areas relative to the characteristics of the substrate and the physicochemical parameters.

\subsection{Living foraminiferal distribution in the Aveiro Lagoon} and continental shelf

The PCA loadings based on living benthic foraminiferal species (Fig. 5) provides general information about the species distribution in function of depth. The distribution maps of the main living species in the study area (Figure 2) allows detailing their environmental distributions. As mentioned, the pattern of species distribution in LA is not always similar to that of TA. This difference may be related to different moments of species reproduction, differentiated rates of species reproduction, and hydrodynamic factors that can both remove and deposit sedimentary materials including empty foraminiferal tests and living organisms. In paralic environments, total (living + dead) foraminiferal assemblages are strongly influenced by the movement of water masses that determine the distribution of living assemblages, and by post mortem transport that may occur in areas characterized by strong hydrodynamics (Duleba and Debenay, 2003, Duleba et al., 2005).

This work is based on the analysis of zonation as a function of depth which is an artificial approach. Although depth by itself is not the major limiting factor of the foraminiferal distribution, several parameters greatly change in general with depth and are related to it in the study area. Salinity variations are one of the parameters that influencing more foraminiferal distribution in coastal areas (de Rijk, 1995; de Rijk and Troelstra, 1997; Duleba et al., 2005). In Ria de Aveiro, the longitudinal distribution of salinity depends on rivers inflow at the end of each channel in the innermost region of the lagoon, and the action of tidal currents. In light of it, salinity significantly decreases at the end of the channels where other variables also markedly change, such as temperature, pH, and Eh (Martins et al., 2010, 2013, 2015b, 2016b). In the inner lagoonal areas, the degree of confinement and eutrophication as well as pollution by metals also increase (Martins et al., 2010, 2013, 2015b, 2016b). In confined and eutrophic environments, depending primarily on the organisms' abundance and respiration rates, oxygen demand may exceed the oxygen supply and, thus sediments become frequently anoxic a few millimeters below the surface, even when the overlying waters are well-aerated (Bernhard and Sen Gupta, 1999). Several benthic foraminifera can tolerate low-oxygenated, anoxic and even sulfidic conditions (Bernhard and Sen Gupta, 1999). However, oxygen depletion is a stressing factor for some species, causing decrease in standing crops and species diversity.

In estuaries, particularly in meso- to micro-tidal temperate environments, different kinds of stress disturb the living communities and cause significant variability in benthic fauna communities. As a result, the composition of 
benthic foraminiferal assemblages reflect the complex interaction between biotic and abiotic parameters and their multiple changes in space and time (Debenay et al., 2000). On the other hand, foraminifera from transitional environments are, in general, well adapted to strong salinity fluctuations (Debenay et al., 1996) but their abundance tends to increase from low salinities (0.5) to typical marine salinities (35). The low salinity of brackish lagoons and marshes favors low-species diversity; in these areas, the assemblages are composed by agglutinated foraminifera and a few calcareous species (e.g. Ammonia and Elphidium; Armstrong and Brasier, 2005). In waters with salinities higher than sea water, the number of species and standingcrops also decreases abruptly (Lin, 1992). These changes are also observed in the foraminiferal assemblages of the Aveiro Lagoon, on the other hand, diversity increases in oceanic environments and as the depth increases, at least for TA as observed in this work and also by Levy et al. (1995).

Nine different patterns of distribution of the main living species, considering the highest relative abundance of the main species, were identified in the study area.

Living assemblages with pattern 1 (LA-P1) include species found in the entire Aveiro Lagoon, which reach relatively high percentages in the lagoon and have much low abundance or are rare or were not found in oceanic environments, such as: $A$. tepida (Fig. 2 A.1; up to 84\%), $H$. germanica (Fig. 2 C.1; up to 79\%), E. margaritaceum (Fig. 2 H.1; up to $52.5 \%$ ), T. inflata (Fig. 2 R.1; up to $36 \%$ ), C. williamsoni (up to $8 \%$ ) and $A$. parkinsoniana (up to $7.7 \%$ ).

The Ammonia genus is the most common benthic foraminiferal taxon in the shallow waters of marginal marine settings (Debenay and Guillou, 2002; Langer and Leppig, 2000). Ammonia tepida (Fig. 2. A.1) occurs in all the Ria de Aveiro but its relative abundance reduces significantly in the lagoon inlet. It is one of the main living species in this lagoon and tolerates reduced salinity and high stress caused by metals and organic pollution (Martins et al., 2010, 2013, 2015 b, 2016b). These characteristics have been also reported in several studies (e.g. Samir and El-Din, 2001; Abu-Zied et al., 2007; Caruso et al., 2011; Cosentino et al., 2013; El Naby et al., 2018). This species is an euryhaline, cosmopolitan species that can grow and reproduce at salinities from 13 to 40 (Almogi-Labin et al., 1992; Abu-Zied et al., 2007). Martins et al. (2016a) found this species as living in salinities ranging from 3.2 to 82.8; however, its density decreases in the highest salinities of saltpans. Its frequency increases in areas with fine grained substrate (Abu-Zied et al., 2007) and its positive correlation with TOC has been considered as an indication of an opportunistic behavior by taking advantage of nutrient availability under adverse conditions due to pollution (El Naby et al., 2018).

A similar trend is verified in the study area for $H$. germanica (Fig. 2. C.2) that is also recognized by its tolerance to several kinds of pollutants (Martins et al., $2016 \mathrm{a}, \mathrm{b}$ ). It has been considered as a significant indicator species of all transitional settings from the subtidal to the middle marsh, being associated to large environmental range (Armynot du Châtelet et al., 2018).

Haynesina germanica sequesters chloroplasts from all types of diatoms, but mainly bears chloroplasts of pennate diatoms (Pillet et al., 2011). In the Atlantic temperate transitional environments, $H$. germanica is the most euryhaline and opportunistic hyaline species, marking the transition between agglutinated species from upper paralic environments (where they are dominant) to calcareous ones from areas with higher marine influence, being progressively replaced by $A$. tepida (Redois and Debenay, 1996; Debenay et al., 2000; Debenay and Guillou, 2002).

Elphidium margaritaceum (Fig. 2 H.1) was recorded mainly in the Aveiro Lagoon. This species mainly occurs in the central and external sectors of this lagoon and is rare in both assemblages in marine settings. It is a lowest intertidal/shallow subtidal species and prefers water with salinity near the marine one $(\sim 29 \%$ ) and tolerates low $\mathrm{pH}$ conditions ( 6.6 ; Martins et al., 2016 b). Elphidium margaritaceum apparently bears chloroplasts of a greater variety of diatoms (Pillet et al., 2011) and probably avoids the inner lagoon areas where the turbidity and surface sediments instability increase under the effect of tidal currents in shallow waters and decreases the salinity and the $\mathrm{pH}$ values.

Trochammina inflata was found in all marsh areas (Armynot du Châtelet et al., 2018) and dominates in many high and middle marsh zones worldwide (e.g., de Rijk and Troelstra, 1997). This species can live attached on hard substrates, resisting to strong speed of tidal currents (Debenay et al., 2015). In the Ria de Aveiro, its percentage increases from the inlet towards the inner ends of the channels where prevails a wide range variability of physicochemical parameters, namely temperature, salinity, $\mathrm{pH}$ and $\mathrm{Eh}$ (Martins et al., 2016a).

Ammonia parkinsoniana is more sensitive, not only to pollution but also to changes in environmental physical conditions, than A. tepida (Poag, 1976) and can also be observed in the Aveiro Lagoon where this species is much less abundant than A. tepida. Poag (1976) observed that temperature and salinity are the most determinant factors in the control of the distribution of A. parkinsoniana.

Cribroelphidium williamsoni reached relatively high percentages ( $8 \%$ ) in the external sector of the Ria de Aveiro, decreasing in internal lagoonal areas. It can sequester and uses endosymbiontic diatoms chloroplasts (Knight and Mantoura, 1985; Pillet et al., 2011) and thus it needs light. Probably because of it, C. williamsoni has been commonly found in shallow waters, tidal ponds, mud flats and close to the vegetation boundary of the saltmarshes and is related to large environmental range (Müller-Navarra et al., 2016; Roberts et al., 2016; Armynot du Châtelet et al., 2018). The turbidity caused by the tidal currents at the ends of the channels and the presence of eutrophic and contaminated 
sediments by metals may limit the occurrence of this species in the inner zones of the Aveiro lagoon.

Living assemblage with pattern 2 (LA-P2). Some species thrive in the inner lagoonal areas where they can reach relatively high percentages in LA but are much less abundant in the nearby marine environments, such as C. excavatum (Fig. 2 N.1; up to $48 \%$ ), E. oceanense (Fig. 2 O.1; up to $45 \%$ ), $M$. fusca (Fig. 2 P.1; up to 30\%), H. manilaensis (up to 13\%), T. salsa (up to $13 \%$ ), E. macrescens (up to $8 \%$ ) and T. irregularis (up to $7 \%$ ).

Cribroelphidium excavatum is a good indicator of tidal channels and tidal flats (Armynot du Châtelet et al. 2018). Elphidium oceanense is able to migrate farther up the marsh and upstream (Scott et al., 1979; Serandrei-Barbero et al., 1999). As mentioned, both species can migrate to inner areas of the Aveiro Lagoon but E. oceanense seems to be less successful in zones with less marine influence.

Miliammina fusca is a quite common species in marsh areas (Armynot du Châtelet et al. 2018) and in worldwide paralic environments, associated with direct freshwater influence (Debenay and Guillou, 2002). It is the most ubiquitous agglutinated shallow-water species (Murray and Alve 1999, $\mathrm{a}, \mathrm{b})$ and is considered as an indicator species of the lowmiddle marsh zone (Varekamp et al., 1992; Camacho, 2012).

Haplophragmoides manilaensis, T. salsa, E. macrescens and T. irregularis are euryhaline and eurythermic species adapted to low salinity conditions. They are frequent species in Portuguese estuarine saltmarshes, where they tolerate extreme adverse conditions at the limit of their environmental tolerance (Fatela et al., 2014). Entria macrescens, for instance, is a good indicator for middle and high marshes where this species can dominate foraminiferal assemblages (de Rijk and Troelstra, 1997; Horton et al., 2005; Armynot du Châtelet et al., 2009, 2018), since it is one of the most tolerant species to subaerial exposure (Scott and Medioli, 1978, 1980). Trochamminita irregularis is common at transitional environemnts from the lower to the upper saltmarsh where it can dominate the living assemblage of foraminifera (up to 97\%; Lübbers and Schönfeld 2018). It was punctually recognized in the living foraminiferal assemblage of the Ria de Aveiro (up to 6\%).

Living assemblage with pattern 3 (LA-P3). Some species reached relatively high frequency in the external sector of the

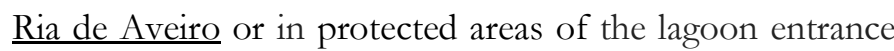
such as $A$. beccarii (Fig. 2 Q.1; up to 43\%), C. gerthi (up to $18 \%$ ), B. elongata/B. gibba (up to 10\%), E. complanatum (up to $5 \%$ ), Q. lata (up to $5 \%$ ) and S. vivipara (up to $5 \%$ ).

Ammonia beccarii is a stenobathytic species exhibiting a distribution that spans narrow depth limits, being characteristic of the inner and mid continental shelf (Schönfeld, 2002; Murray, 1991). Cribroelphidium gerthi is frequent in sediments with high content on sand of the inner to mid continental shelf (Pujos, 1976; Mendes et al., 2004). In the study area, the highest relative abundance of this species in LA was found under strong hydrodynamics at the lagoon mouth, which reveals that it tolerates that conditions. Bulimina elongata/B. gibba is common from the coast up to $150 \mathrm{~m}$, being rare beyond this depth in the Portuguese continental margin (Levy et al., 1995). Elphidium complanatum is common on the Portuguese continental shelf, reaching higher relative abundances at shallow depth environments (Levy et al., 1995). Quinqueloculina lata is a stress tolerant species to anthropogenic pollution (Mangoni et al., 2016). This species was found living in the Aveiro Lagoon mouth reaching relatively high abundance (up to $5 \%$ ), under the influence of strong tidal currents. Like $Q$. seminula, it seems to be tolerant to high stress caused by strong hydrodynamic conditions, but seems to heve smaller tolerance to confinement and pollution caused by metals. Spirillina vivipara is an epifaunal species that can be found in deep sea environments (Morigi et al., 2012) and also in brackish waters with salinities higher than 7 , the ecological threshold for this taxon (Bradshaw, 1961).

In the study area all these species seem to prefer salinities near the marine one (30-33.7) and tolerate a certain degree of disturbance caused by hydrodynamics. They probably populate the lagoon entrance because they are transported from oceanic coastal environments and due to favorable food conditions.

The patterns 1 (LA-P1) and 2 (LA-P2) are similar to other microtidal estuaries such as that have been studied along the eastern and southern Brazilian coast (Duleba et al., 2005). These Brazilian estuaries show a succession of marine and mixohaline calcareous species (near the mouth) that changes to mixohaline calcareous and agglutinated species, then to agglutinated species alone, and finally to Miliammina fusca and thecamoebians in the upper reaches (Duleba et al., 2005).

Living assemblage with pattern 4 (LA-P4). Some species reach the highest relative abundance at the lagoon inlet area, such as R. concava (Fig. 2 E.1; up to $61 \%$, L. ochracea (Fig. 2 I.1; up to $52 \%$ ), Q. seminula (Fig. 2 M.1; up to $47 \%$ ), G. praegeri (up to $17 \%$ ), P. haynesi (up to $12 \%$ ), R. helgolandica (up to $11 \%$ ) and R. gonzalezi (up to $11 \%$ ).

Rotaliammina concava is an epifaunal species found frequently attached to sand grains in the study area and seems to be euryhaline since it was found living along all the Aveiro Lagoon channels (Fig. 2 E.1). However, it dominates the living assemblage of the Aveiro lagoon inlet (reaching $61 \%$ ), one of the most hydrodynamic environments of the study area, which means that it is likely able to tolerate high degree of environmental stress caused by strong hydrodynamics.

Lepidodeuterammina ochracea (Fig. 2 I.1) was found with low relative abundance both in the Aveiro Lagoon and in the adjacent inner to mid shelf, except in the lagoon inlet, where this species dominates the living assemblage (reaching $52 \%$ ). It has been frequently recognized in shallow marine settings (Murray, 1970; Debenay, 1978; Yassini and Jones, 1995), Iceland saltmarshes (Lübbers and Schönfeld, 2018) and 
brackish water environments and was even found living in fresh water, from Río de la Plata, Argentina (Boltovskoy, 1957). However, it was found in the epibathyal zone of the Gulf of Cadiz, strongly affected by the Mediterranean Outflow Water (MOW), occupying an epibenthic microhabitat (Schönfeld, 2002). It is an obligate attached species (Sen Gupta and Smith, 2013).

In lagoonal environments, $Q$. seminula can be found in the middle and high marshes and associated tidal channels (Armynot du Châtelet et al., 2018). The genus Quinqueloculina is commonly found in shallow coastal environments, at the inner shelf and in transitional environments, with salinity close to normal marine one (Swallow, 2000). In the Ria de Aveiro, Q. seminula is frequent in sandy sediments of subtidal channels with salinity close to the normal marine one (Martins et al., 2010, 2013, 2015 b, 2016b) but high relative abundance of this species was found in muddy sediments too (Martins et al., 2010, 2013). Similar observations were done by El Naby et al. (2018) who recorded a positive correlation of this species with salinity and TOC. According to Abu-Zied et al. (2007), stressing conditions should induce a rapid reproduction of this species giving place to a large number of individuals within short time.

Gavelinopsis praegeri is a clinging epifaunal species, generally living in a wide range of water depth (de Stigter et al., 1996; Murray, 2006). It is a quite common species in the Aveiro continental shelf but can drive into the lagoon. In the study area, it reached the highest relative abundance under strong tidal currents in the lagoon mouth. In northern Europe, it is a common species in coarse sediments under high-energic conditions (Murray, 2006).

Paratrochammina haynesi was found in the whole lagoon and in the inner to mid continental shelf but reached the highest percentage in the lagoon inlet. Remaneica belgolandica is a common species in European transitional and coastal marine environments (Brönnimann and Whittaker, 1990; Pujos, 1976). It was found living in the external and central sectors of the Aveiro Lagoon and in the nearby continental shelf, but it also reached its highest percentage (up to $11 \%$ ) in the lagoon inlet.

Living assemblage with pattern 5 (LA-P5). Some species were found in the inner to middle continental shelf but reached the highest relative abundance in protected lagoonal harbor areas located close to the lagoon entrance such as $B$. ordinaria (Fig. 2 D.1) and N. stella.

Bolivina ordinaria and Nonionella stella were found associated to fine-grained sediments with relatively high organic matter content and associated with dysoxic conditions in harbor areas near the Ria de Aveiro mouth (Martins et al., 2013). Bolivina ordinaria can tolerate lowsalinity and was found living in several channels in the Aveiro Lagoon, under wide range of physicochemical parameters (Martins et al., 2010, 2013, 2015 b, 2016b). Camacho (2012) found B. ordinaria in the Guadiana estuary (south Portugal) and suggested that low temperatures indirectly and food availability directly could drive the reproduction and proliferation of this species inside that estuary. Nonionella stella is an opportunistic species, that can rapidly explore ephemeral resources, due to its high reproductive rate (Silva et al., 1996). It is well represented in poor oxygenated habitats (Bernhard and Sen Gupta, 1999) and survives more than two months of anoxia (Moodley et al., 1997); apparently, it is an aerobic facultative species (Bernhard and Sen Gupta, 1999; van der Zwaan et al., 1999). However, N. stella was not found living in the central and inner regions of the Aveiro Lagoon.

The LA-P5 is similar to those found in inner shelf regions of southern Brazilian coast (Duleba et al 2005, Duleba et al 2018).

Living assemblage with pattern 6 (LA-P6). Some species can be found living both in the outer sector of the lagoon and in the inner to mid continental shelf, such as as $P$. mediterranensis (Fig. 2 F.1; up to 54\%), B. psendoplicata (Fig. 2 J.1; up to 50\%), C. jeffreysii (Fig. 2 S.1; up to 25\%), R. auberii (up to $20 \%$ ), G. crassa rossensis (up to $18 \%$ ), G. minuta (up to $11 \%$ ), $H$. nitidula (up to $10 \%$ ), $N$. dentaliniformis (up to $9 \%$ ) and $\mathrm{R}$. adaperta (up to $7 \%$ ).

Planorbulina mediterranensis is an obligate attached species (Sen Gupta and Smith, 2013) and can live attached by the spiral side to macroalgae and rocks (Murray, 1971) and is therefore an epiphyte or epilithic species (Coppa and Di Tuoro, 1995). The granulometry of the sediment is a limiting factor for this species that reaches its maximum abundance in coherent rock or coarse sediment containing gravel and sand with mean grain size $>100 \mu \mathrm{m}$ (Mathieu, 1986). This species is also found living in the Aveiro Lagoon entrance but it reached the highest percentage in the Aveiro mid shelf, reaching $54 \%$ in front of the lagoon mouth.

Bolivina pseudoplicata was found in marsh environment of the Portuguese rivers at salinities ranging between 12 and 25 and was dominant in the tidal marsh at salinity of 25 (Fatela et al., 2007). It was more abundant on the inner shelf in front of the lagoon outflow than in the Aveiro Lagoon. The different distribution pattern of this species and B. ordinaria suggests that the latter is resistant to more unfavorable and stressing environments due to confinement and eutrophication. Bolivina pseudoplicata seems to prefer more open spaces associated with a certain sedimentary disturbance caused by the littoral drift and waves.

Cribrostomoides jeffreysii is an infralittoral species and may extend its distribution to the epibathyal zone. In the Canadian Arctic, for instance, it is very common between 60-360 m, not occurring at deeper environments (Vilks, 1969). In the Antarctic, it is one of the most important species, in shallow sediments ( $<20 \mathrm{~m}$; Bernhard, 1989). It is present on all Portuguese continental shelf (Levy et al., 1995). This species was found as living in the Ria de Aveiro but it is much more frequent in the nearby inner to mid continental shelf reaching relatively high percentage (up to 
$25 \%$ ) under the influence of this lagoon outflow. It occupies a wide variety of ecological niches, ranging from the Antarctic ice (Bernhard, 1993), to the cold waters of Alaska (Bergen and O'Neil, 1979), including estuaries, intertidal zones and a large variety of substrates such as, for example, ice, sponges, rocks and sand (Bernhard, 1993). Cribrostomoides jeffreysii is a tolerant species to oxygen deficiency (Bernhard, 1993; Sen Gupta and Machain-Castillo, 1993).

Rotorbis auberii (or Discorbis mira) reached the highest relative abundance between $30-60 \mathrm{~m}$ in substrates consisting of coarse sand (Martins et al., 2017). This species is common in the Posidonia meadows, in the northern region of the Iberian Peninsula (Colom, 1974). Cribroelphidium gerthi is frequent on sandy sediments of the inner to mid continental shelf (Pujos, 1976; Mendes et al., 2004). In the study area, the highest relative abundance of this species was also found under strong hydrodynamic conditions at the lagoon mouth.

Globocassidulina crassa rossensis (as Cassidulina obtusa) is present at all depths, of the Portuguese continental shelf with an abundance that can reach 9\% (Levy et al., 1995). It was found living in the Aveiro continental shelf between 20$80 \mathrm{~m}$. The highest relative abundance of this species was found in a zone where the oceanic fronts are favorable to the accumulation of organic matter. Globocassidulina minuta is frequent in neritic and bathyal environments (Murray, 1991). It reaches higher relative abundances in sediments rich in organic matter and poor in oxygen due to high productivity (Sen Gupta and Machain-Castillo, 1993). It is quite common (reaching up to $5 \%$ ) in the Aveiro inner and mid shelf influenced by the lagoon outflow.

Hanzawaia nitidula is an epifaunal and euribathyal species. It appears in the inner infralittoral zone and becomes frequent in the circalittoral region south of Gasconha, being common in the bathyal domain (Pujos, 1976) down to about 3,200 m (Caralp et al., 1970). The number of individuals increases in sandy substrates (Pujos, 1976) but it seems to tolerate the oxygen depletion increasing the number of pores than specimens from better oxygenated waters (Perez-Cruz and Machain-Castillo, 1990).

Nodulina dentaliniformis (as Reophax dentaliniformis) is an eurythermal and eurybathic cosmopolitan species (Murray, 1991; Hermelin and Scott, 1985) being present in different marine settings (Anderson, 1963; Hermelin, 1983, 1987; Schröder-Adams et al., 1990) and fjord environments (Polovodova et al., 2009). Rottgard (1952) collected living organisms of $\mathrm{R}$. dentaliniformis, in the Kiel Bay, salinities between $9-20 \%$. It is a superficial infaunal species, living in surface sediments, mainly in the interval between $0-0.5 \mathrm{~cm}$; their abundance decreases rapidly with depth in the sediment (de Stigter et al., 1998). In the study area, this species was found living in the outer sector of the lagoon but reached relatively high percentage $(9.3 \%)$ on the inner to mid shelf which indicates tolerance to a certain substrate instability due to high energy, as also observed by Romano et al. (2018).
RESEARCH PAPER

Rotaliammina adaperta can dominate the living assemblage of saltmarshes (Lübbers and Schönfeld, 2018). In the study area, it was more frequent (up to $7 \%$ ) in the inner to mid continental shelf but also was found living in the Aveiro lagoon.

Living assemblage with pattern 7 (LA-P7). Some species are mostly represented in Aveiro Continental Shelf, such as C. lobatulus (Fig. 2 L.1; up to 47\%) and C. ungerianus (Fig. 2 G.1; up to $20 \%$ ) and B. spathulata (up to $11 \%$ ).

Cibicidoides lobatulus is a facultative attached species (Sen Gupta and Smith 2013) and a passive suspension feeder (Murray 1991); in finer grained habitats, it can occur attached to several kinds of substrates, for example, polychaeta tubes (Steinsund 1994). It also supports significant variations in salinity that can vary between "normal" and "estuarine" (Williamson et al., 1984), thus can be found in the Aveiro Lagoon. Its higher relative abundance was found in the lagoon mouth under strong hydrodynamics with very adverse environmental conditions, intolerable for many species. The relative abundance of this species reduces significantly in other lagoonal areas.

Cibicidoides ungerianus is quite frequent in the Aveiro continental shelf but it reached high relative abundance in the lagoon mouth and decreased in percentage inward. Both C. lobatulus and C. ungerianus are generally associated with coarse-grained sediment and tolerate high degree of disturbance caused by hydrodynamics, thus are related in the study area to well-oxygenated zones with low to moderate productivity. Bolivina spathulata is a heterobathyal species (Alavi, 1988), occurring on both continental shelf and bathyal environments. It has a wide distribution, being registered in all the oceans (Murray, 1991). It is often dominant in oxygen-poor environments rich in organic matter due to high productivity (Alavi, 1988). In Portugal, this species has in general a similar pattern of distribution as $U$. peregrina and $C$. carinata, at least in TA, increasing in neritic environments from $100 \mathrm{~m}$ depth and is an indicator of the upwelling phenomena (Levy et al., 1995). In the study area, it occurs in the LA of the inner to mid shelf, reaching $12 \%$ in front of the Aveiro Lagoon outflow probably due to food abundance.

This pattern 7 (LA-P7) is similar to that found in the internal continental Shelf of Ubatuba and São Sebastião, Brazil (Duleba et al., 2015, 2018).

Living assemblage with pattern 8 (LA-P8). Some species were not found as living in the lagoon and are common or present in the nearby inner to mid shelf such as $P$. bartrami (up to $14 \%$ ), T. squamata (up to $7 \%$ ), B. variabilis (up to $5 \%$ ), G. gordialis (up to $5 \%$ ), P. murrayi (up to $5 \%$ ), R. anglica (up to $5 \%$ ) and $G$. crassa (up to $3 \%$ ).

Paratrochammina bartrami has been found in coastal areas in different oceanic settings (Majewski et al., 2012). It was recorded in the LA (up to 14\%) of the Aveiro inner shelf, in a zone under the influence of the littoral drift and the lagoon 
outflow which indicates tolerance to disturbance caused by sediment instability.

Trochammina squamata is a euryhaline species ( $\mathrm{Gu}$ et al., 2017) that has been recorded in coastal areas under the influence of several rivers (Li et al., 2014) and also in abyssal environments with an epifaunal and shallow-infaunal microhabitats (Enge et al., 2012). In the study area, this species was found living in the inner to mid shelf, on the gravely deposits, which would indicate a certain tolerance to relatively high hydrodynamic conditions.

Discorbinella bertheloti is a frequent species in the Portuguese continental shelf where it can present great variability of forms, possibly, by being fixed and deformed as a function of the substrate to which it adheres (Levy et al., 1995). The maximum abundance of living organisms is in the first centimeter of the sediment surface, its preferred microhabitat (Rathburn and Corliss, 1994). It was identified as living in Aveiro mid shelf in substrates formed by coarse sand, reaching a relative abundance of $6 \%$, between $50 \mathrm{~m}$ and $80 \mathrm{~m}$ depth.

Bolivina variabilis is commonly misclassified with other species of bolivinids, such as B. ordinaria because it has a similar form; the hexagonal pattern that surrounds the pores of the shell is hardly visible in magnifications used in binocular microscopes. It is therefore difficult to establish their distribution. However, Bolivina variabilis is a common species in the sub-tidal and internal to mid neritic marine settings (Sliter, 1970; Mendes et al., 2004). In the study area, it was found living in the inner to mid continental shelf mostly in front of the Aveiro Lagoon outflow.

Glomospira have been included by Jones and Charnock (1985) in the group of surface-dwelling herbivores, detritivores and omnivores, that can be present in bathyal environments (Mello e Sousa et al., 2017). Glomospira gordialis is present in the study area in the mid shelf on coarse sediments (gravelly deposits).

Portatrochammina murrayi was found as living on the inner to mid shelf in front of the Aveiro Lagoon mouth. This species has a wide bathymetric range (Murray and Alve 2011). It has been found, for instance, in coastal areas (Debenay et al., 2001) but also on the top of abyssal hills and on the adjacent plain in the area of the Porcupine Abyssal Plain, northeast Atlantic (Stefanoudis et al., 2016). Remaneica anglica occurs at the England continental shelf (Brönniman and Whittaker, 1990). It was identified (up to 5\%) off the coast of Aveiro, on gravel deposits of the mid shelf. Globocassidulina crassa was found mostly in front of the Aveiro Lagoon outflow which indicates an opportunistic behavior related to the availability of food induced by the lagoon outflow, in addition to oceanic upwelling events. Globocassidulina crassa consumes fresh phytoplankton materials (Suhr and Pond, 2006).

Living assemblage with pattern 9 (LA-P9). Some species are much common in the mid to outer shelf and upper slope such as C. laevigata/C. carinata (Fig. 2 B.1; up to 9\%) and for instance G. umbonata (up to $7 \%$ ).

Cassidulina laevigata/C. carinata lives in the first centimeter of the sediment (Buzas et al., 1993; de Stigter et al., 1998) associated to high organic input, low oxygen levels (Corliss and Emerson, 1990; Murray, 1991) and is one of the most opportunistic taxa. Its abundance depends on a pulsed supply of fresh organic matter with high nutrition value (de Rijk et al., 2000), preferentially marine organic detritus (Mojtahid et al., 2009) but it can also feed on degraded organic matter (Caralp, 1989; Schmiedl and Mackensen, 1997). Cassidulina laevigata/C. carinata are one of the most frequent taxa at the Portuguese continental shelf below 95 m water depth (Levy et al., 1995).

Gyroidina umbonata has been recorded in circalittoral and external bathyal biotopes of the European margin (Pujos, 1976; Levy et al., 1995; Contreras-Rosales et al., 2012). In the study area, this species appears at the inner continental shelf, but its percentage tend to increase in the outer shelf and upper slope.

These different patterns of living species distribution in the study area seems to be conditioned by their tolerance to several factors, such as strong hydrodynamics and sediments stability, a wide range of physicochemical parameters, degree of confinement, pollution by metals and organic matter (e.g. Martins et al., 2010, 2013, 2015 b, 2016b) and quality of food (Martins et al., 2017).

Several ecozones can be identified in the study area from species distribution, for instance: the lagoon, in which several zones/compartments are distinguished such as inner lagoonal areas, external to central lagoonal areas, protected harbors and the lagoon inlet area and in oceanic settings: the inner to mid shelf near the lagoon mouth, and the mid to outer continental shelf regions.

\subsection{Comparison of $L A$ and $T A$ distributions of the main foraminiferal species}

Some species have similar distribution patterns in both LA and TA such as for: LA-P2 (C. excavatum, E. oceanense, $M$. fusca, H. manilaensis, T. salsa, E. macrescens and T. irregularis) related to the most tolerant species to large environmental stress caused by large variability of physicochemical parameters and high degree of confinement and pollution by metals; LA-P3 (Cribroelphidium gerthi, Bulimina elongata/B. gibba, Q. lata and S. vivipara) for marine species that populate the lagoon entrance; LA-P4 (R. concava, G. praegeri, P. haynesi and $R$. helgolandica) species that seems to tolerate high degree of disturbance caused by very strong hydrodynamic currents at the marine inlet, which means that few species are able to withstand such conditions; LA-P5 (B. ordinaria, Fig. 2 D.1, D.2; and N. stella) including opportunistic species that can populate areas enriched in organic matter and tolerate very low oxic environments; LA-P6 (P. mediterranensis (Fig. 2 F.1, F.2), B. psendoplicata (Fig. 2 J.1, J.1), C. jeffreysii (Fig. 2 S.1, S.2), 

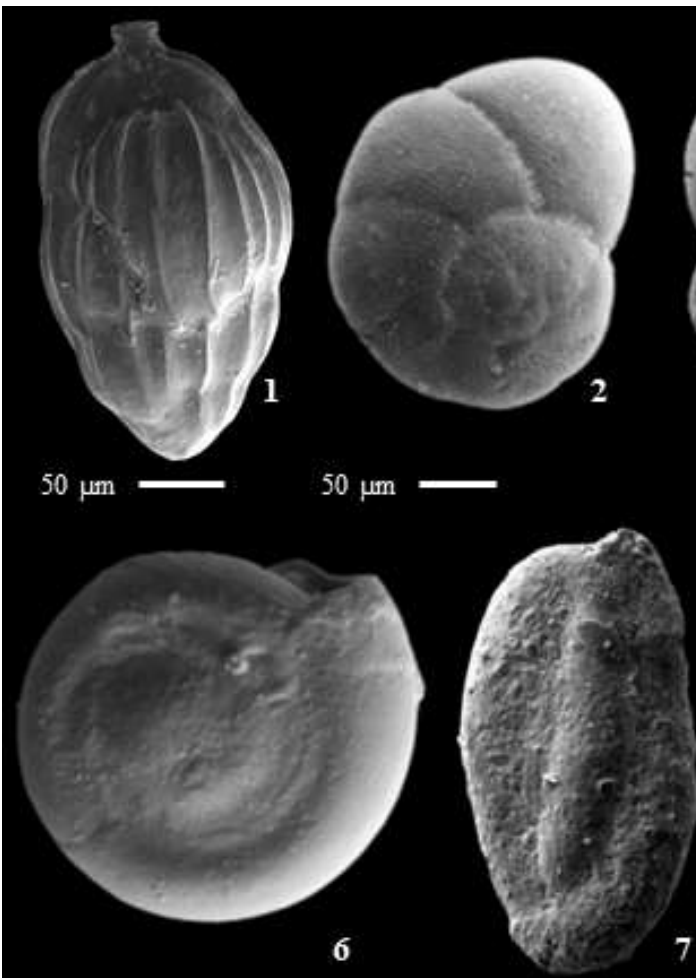

$50 \mu \mathrm{m}$

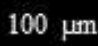

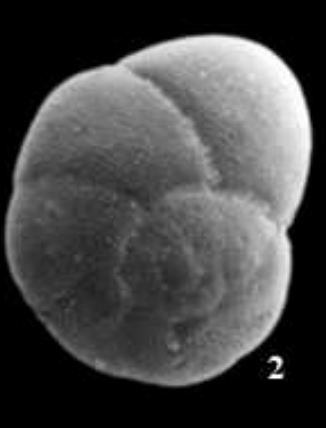

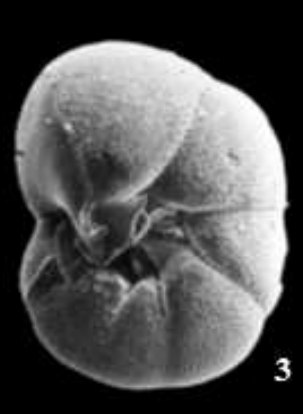

$50 \mu \mathrm{m}$

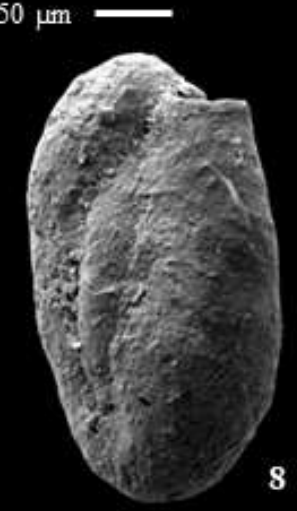

$100 \mu \mathrm{m}$

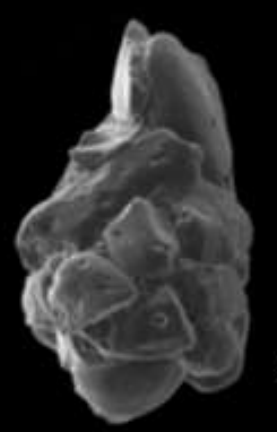

$100 \mu \mathrm{m}$

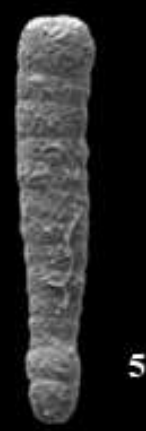

5

$100 \mu \mathrm{m}$

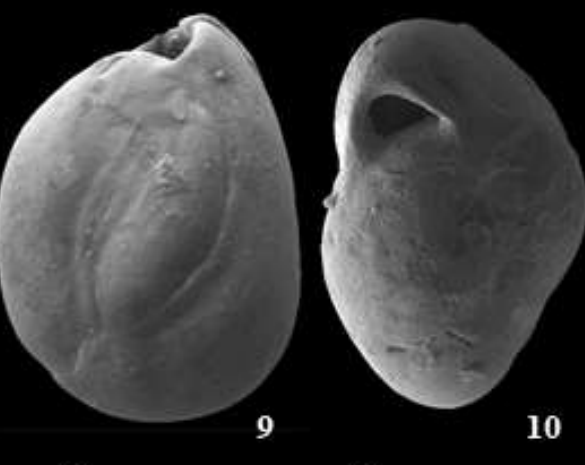

$50 \mu \mathrm{m}$

$50 \mu \mathrm{m}$
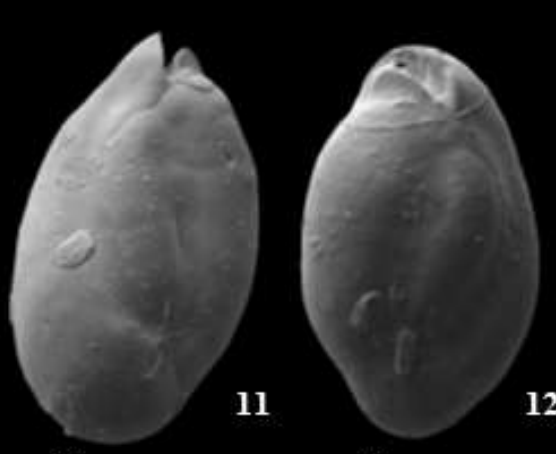

12

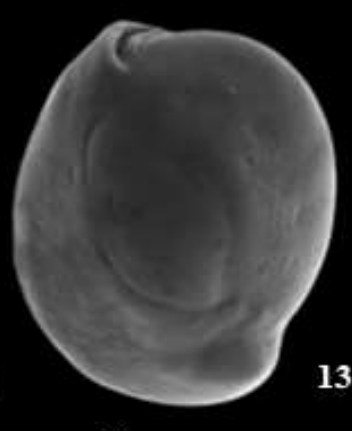

13
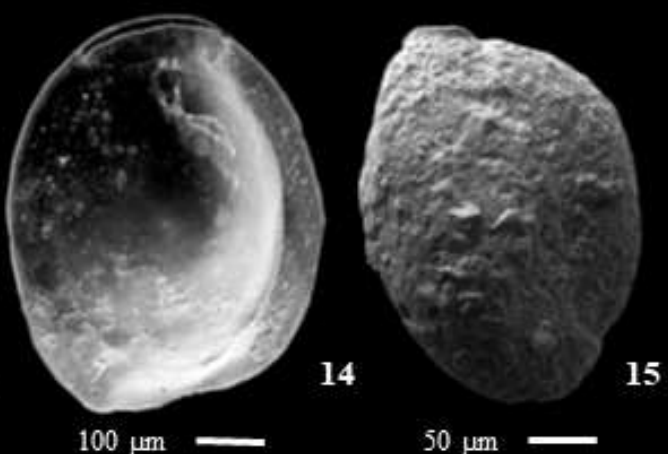

$50 \mu \mathrm{m}$

$50 \mu \mathrm{m}$

$50 \mu \mathrm{m}$

$100 \mu \mathrm{m}$

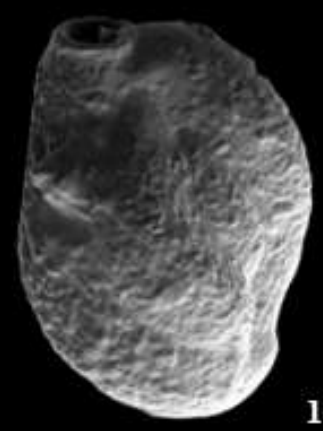

$50 \mu \mathrm{m}$

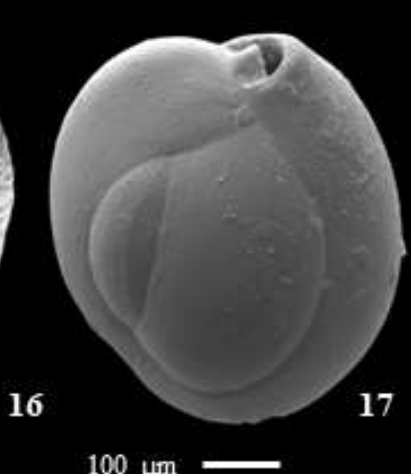

$100 \mu \mathrm{m}$

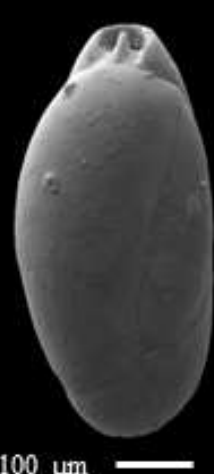

$100 \mu \mathrm{m}$

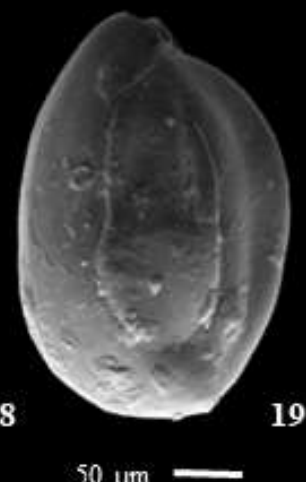

$50 \mu \mathrm{m}=$

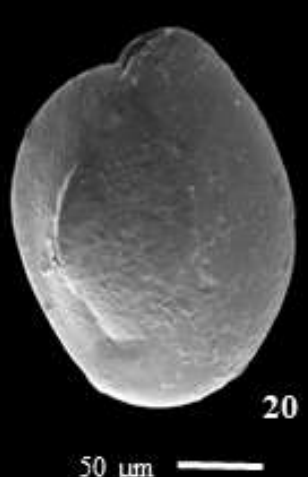

$50 \mu \mathrm{m}$

\section{Plate 17}

Plate 17. 1. Uvigerina mediterranea Hofker, 1932; 2-3. Valvulineria minuta (Schubert, 1904); 4. Lagenammina arenulata (Skinner, 1961); 5. Polysaccammina byperbalina Medioli, Scott and Petrucci, 1983; 6. Cornuspira involvens (Reuss, 1850); 7-8. Miliammina fusca (Brady, 1870); 9-10. Miliolinella circularis (Bornemann, 1855); 11-12. Miliolinella lutea (d'Orbigny, 1839); 13. Miliolinella subrotunda (Montagu, 1803); 14. Pyrgo depressa (d'Orbigny, 1826); 15-16. Quinqueloculina agglutinans d'Orbigny, 1839; 17-18. Quinqueloculina akneriana d'Orbigny, 1846; 19. Quinqueloculina atlantica Boltovskoy, 1957; Quinqueloculina auberiana d'Orbigny, 1839 . 

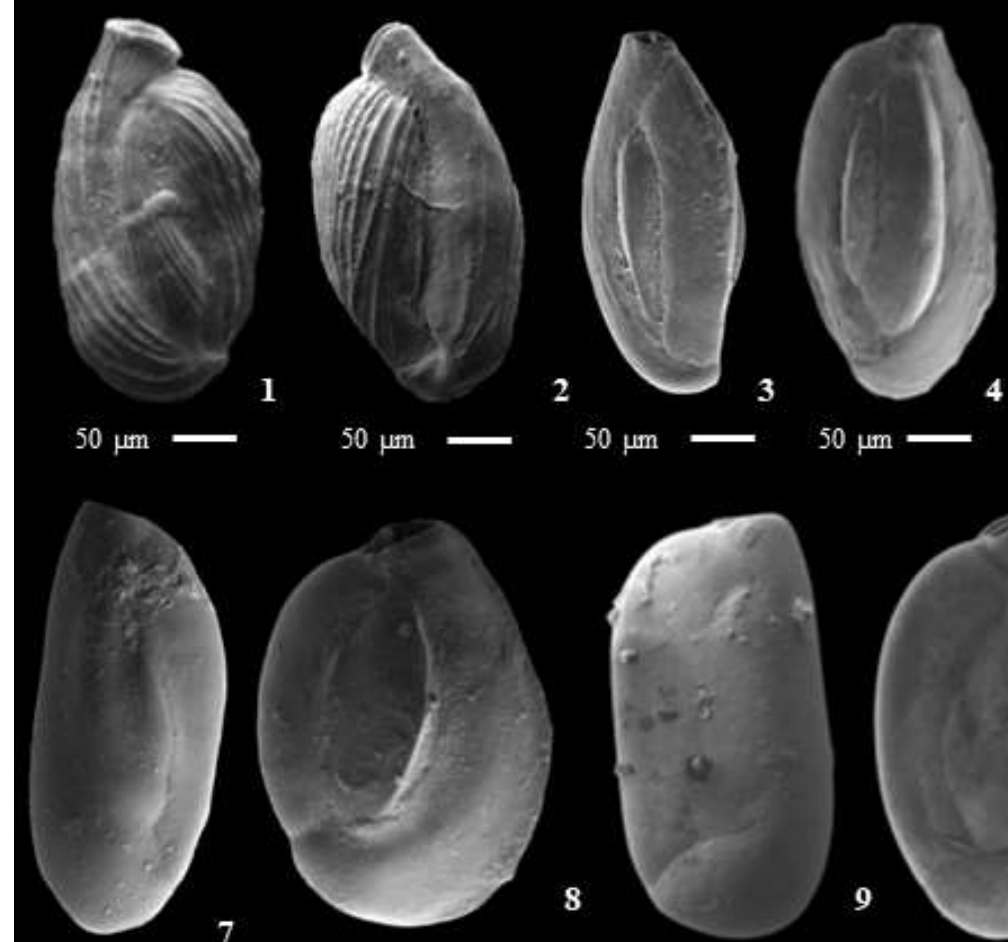

$50 \mu \mathrm{m}$

$50 \mu \mathrm{m} \longrightarrow$
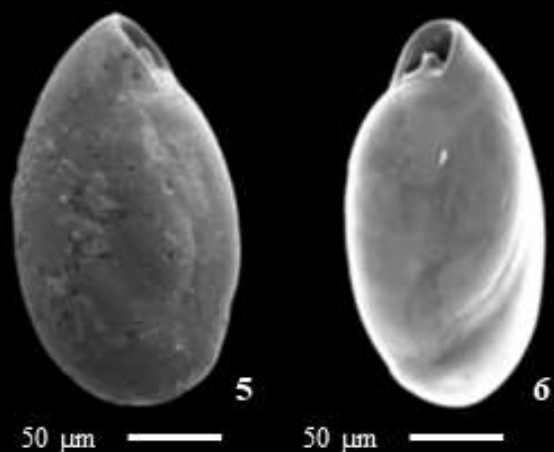

7

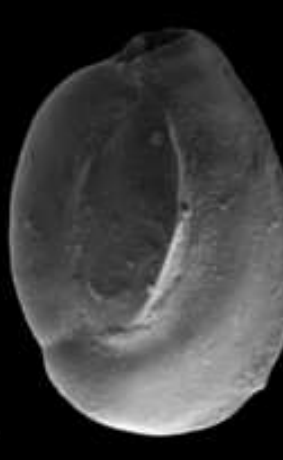

$100 \mu \mathrm{m}$
8

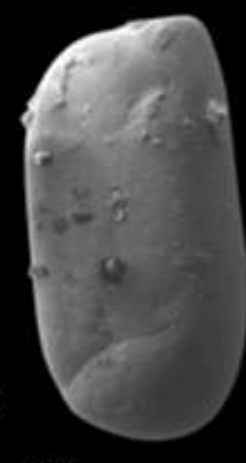

$100 \mu \mathrm{m}$

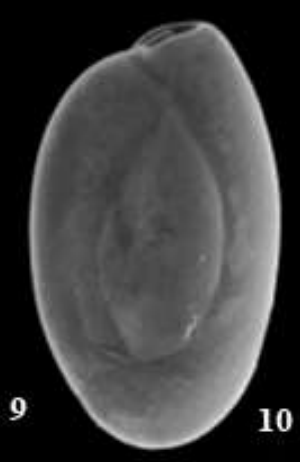

$100 \mu \mathrm{m}$

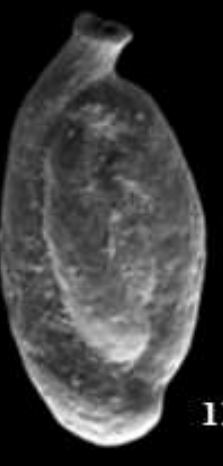

11

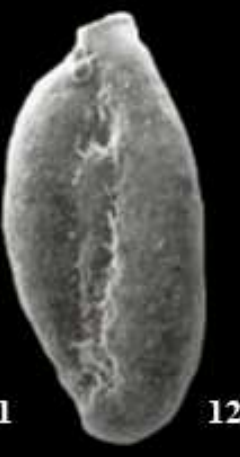

12

$50 \mu \mathrm{m}$

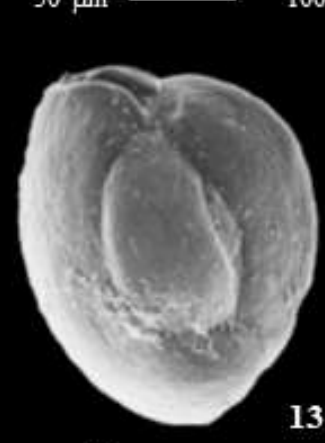

$100 \mu \mathrm{m}$

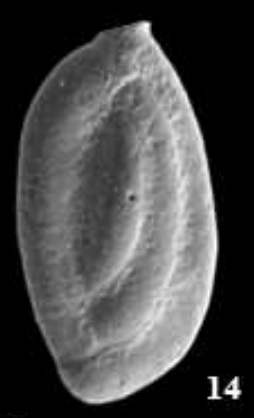

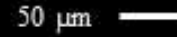

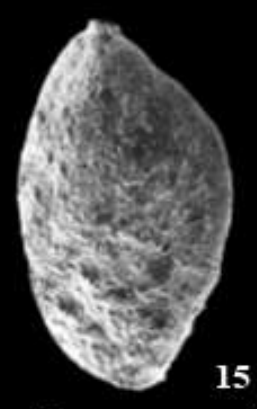

$50 \mu \mathrm{m}$

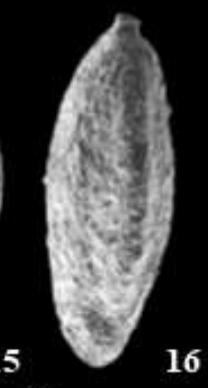

$50 \mu \mathrm{m}-$

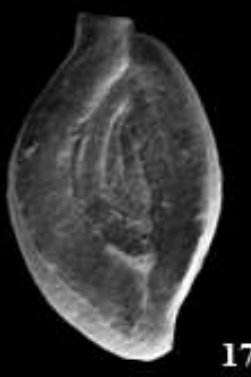

$50 \mu \mathrm{m}$
17

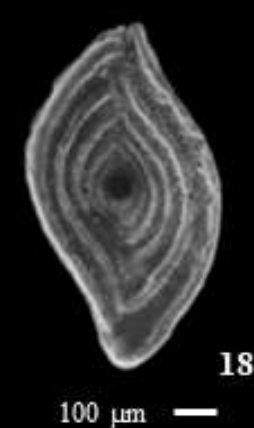

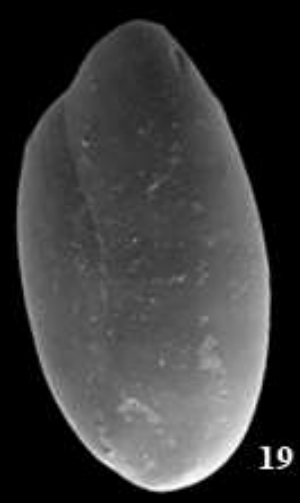

$50 \mu \mathrm{m}$

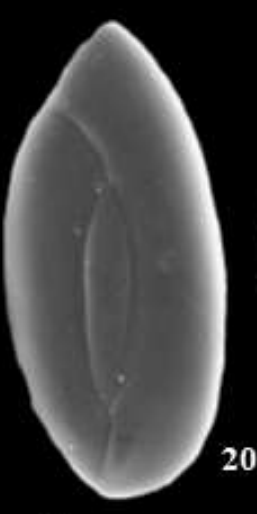

$50 \mu \mathrm{m}$

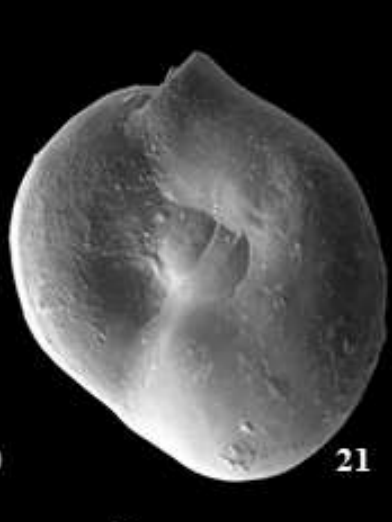

$100 \mu \mathrm{m}$

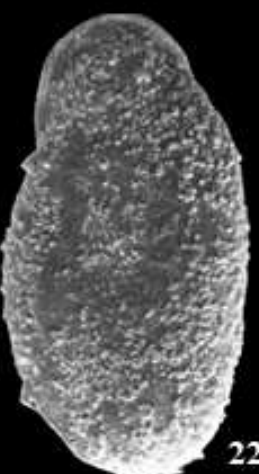

$50 \mu \mathrm{m}$

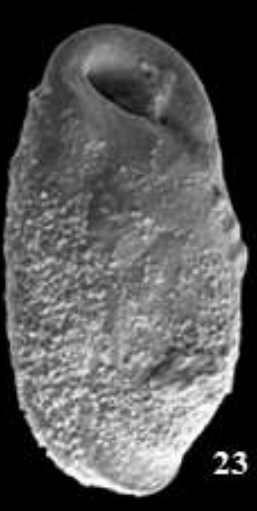

$50 \mu \mathrm{m}$

\section{Plate 18}

Plate 18. 1-2. Quinqueloculina boueana d'Orbigny, 1846; 3-4. Quinqueloculina candeiana d'Orbigny, 1839; 5-6. Quinqueloculina dimidiata Terquem, $1876 ; 7$. Quinqueloculina laevigata d'Orbigny, 1839; 8. Quinqueloculina lamarckiana d'Orbigny, 1839; 9. Quinqueloculina lata Terquem, 1876; 10. Quinqueloculina seminula (Linnaeus, 1758); 11-12. Quinqueloculina stalkeri Loeblich and Tappan, 1953; 13. Quinqueloculina vulgaris d'Orbigny, 1826; 14. Sigmoilopsis elliptica (Galloway and Wissler, 1927); 15-16. Sigmoilopsis schlumbergeri (Silvestri, 1904); 17. Spiroloculina depressa d'Orbigny, 1826; 18. Spiroloculina tenuiseptata Brady, 1884; 19-20- Triloculina oblonga (Montagu, 1803); 21. Ophthalmidium balkwilli Macfadyen, 1939; 22-23. Wiesnerella auriculata (Egger, 1893). 


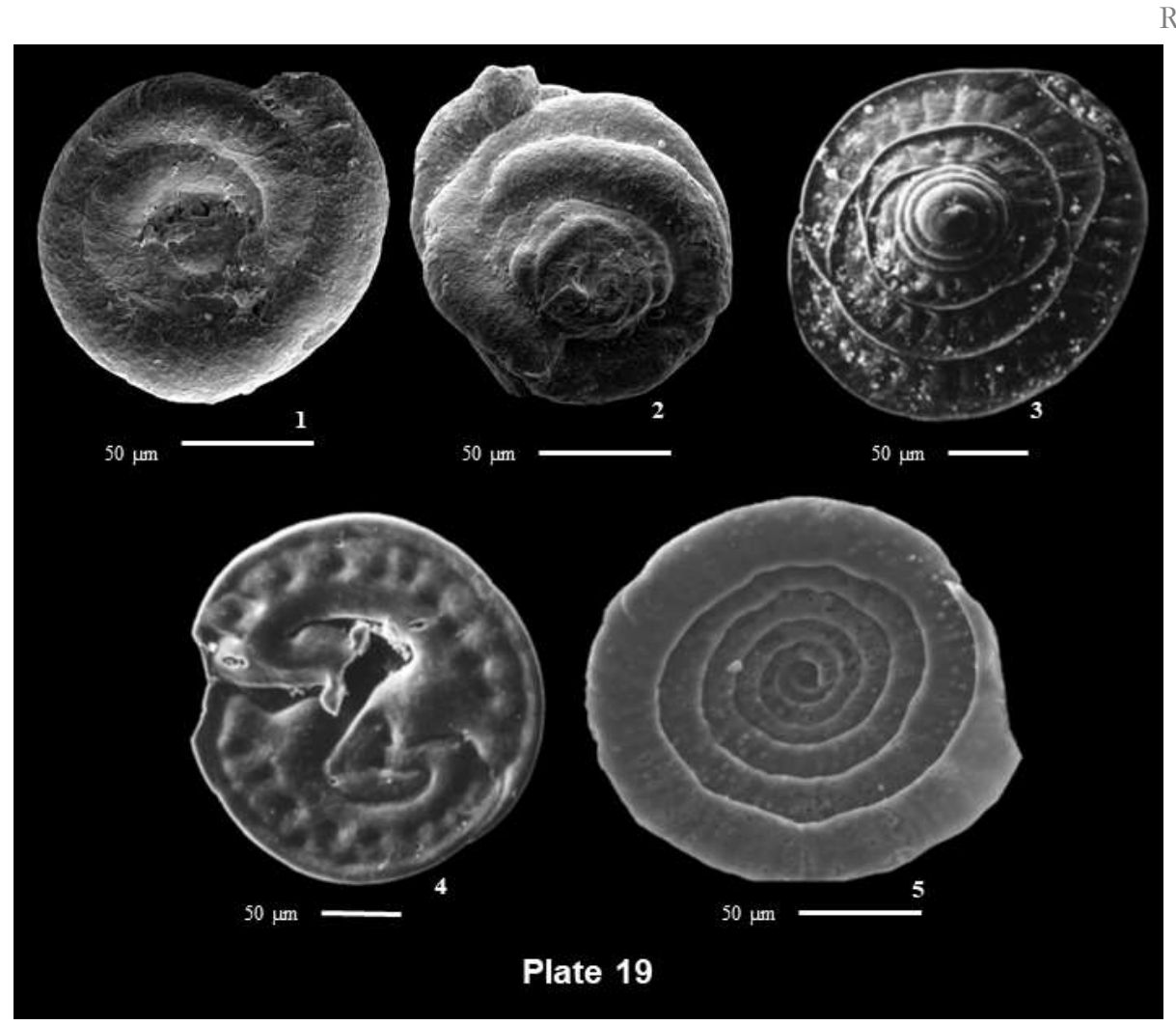

Plate 19. 1-2. Glomospira gordialis (Jones and Parker, 1860); 3-4. Patellina corrugata Williamson, 1858; 5. Spirillina vivipara Ehrenberg, 1843.

R. auberii, G. crassa rossensis and N. dentaliniformis), LA-P7 (C. lobatulus, Fig. 2 L.1, L.2) and LA-P8 (P. bartrami, T. squamata, G. gordialis, P. murrayi and R. anglica) that populate relatively stable marine environments.

The species of LA-P1 such as A. tepida (Fig. 2. A.1, A.2), H. germanica (Fig. 2 C.1, C.2), E. margaritaceum (Fig. 2 H.1, H.2) and T. inflata (Fig. 2 R.1, R.2) have similar distribution patterns in both LA and TA but their distributions are broader in the LA than TA. All these species are typically lagoonal. This result may indicate loss of tests after the organism's death, by taphonomic effect, namely dissolution of carbonate tests, destruction of agglutinated tests or removal of tests by hydrodynamic agents. On the other hand, some species have different patterns of distribution in living assemblage and in TA, for instance, L. ochracea (LAP4) reaches the highest percentages in LA in the lagoon inlet and in the external sector of the Ria de Aveiro and in TA on the gravel deposits of the mid continental shelf; in both cases L. ochracea is related to relatively strong hydrodynamics.

Quinqueloculina seminula (LA-P4) has similar distribution pattern in LA and TA in the Ria de Aveiro but showed different patterns of distribution in marine setings, probably due to the effect of the increase of its reproduction rate in stressing lagoonal environments. Globocassidulina minuta in LA (LA-P6) reached relatively high percentage in front of the lagoon mouth; in TA this species is mostly represented in the outer shelf, where the sedimentation rate is reduced and and does not dilute much the biogenic component of the sediment. The same effect seems to be observed in the distribution of Hanzawaia nitidula (LA-P6), C. laevigata/C. carinata (LA-P9; Fig. 2 B.1, B.2) and G. umbonata (LA-P9) whose occurrence is broader in TA. Bolivina spathulata and $G$. crassa (LA-P7) and R. anglica (LA-P8) have opposite patterns in LA and TA, probably due to different reproduction rates and taphonomic effects.

In TA there are species whose relative abundance seems to increase in the mid to outer shelf and/ or upper slope, but were rare in the LA, such as: B. dilatata (up to $29 \%$ ), B. quadrilatera (up to $20 \%$ ), B. truncana (up to $17 \%$ ), C. oblongus (up to $13 \%$ ), B. tenuata (up to $11 \%$ ), B. difformis (up to $9 \%$ ), C. pachyderma (up to $8 \%$ ), B. compacta (up to $7 \%$ ) and $B$. marginata (up to $6 \%$ ), which indicates differentiated periods of reproduction depending on the oceanographic and environmental conditions.

The analysis of the LA and TA revealed similar patterns of species distribution in both assemblages mostly for lagoonal species and for the most stressing environments caused by strong hydrodynamics, confinement in inner lagoonal areas and stressing conditions caused by depressed levels of oxygen.

The most unusual assemblage was found in the Aveiro Lagoon inlet, including several epifaunal species tolerant to high hydrodynamics. The greatest divergences between the LA and TA associations were found in relatively deep oceanic environments, this is in the outer continental shelf and upper slope. 


\section{Conclusion}

This work presents a checklist of benthic foraminiferal species that can be found in the region of Aveiro (both in total and living associations) and shows the pattern of distribution of the most frequent species in the Aveiro Lagoon and in the adjacent continental shelf and upper slope. The results of statistical analysis designed as function of depth of the main species allowed to identify different patterns of distribution related to different ecoenvironments. It was noted, for instance, that some species can thrive to the inner lagoonal zones and are almost absent in oceanic environments such as $C$. excavatum, E. oceanense, $M$. fusca, $H$. manilaensis, T. salsa, E. macrescens and T. irregularis. Some species are mainly recognized in oceanic settings and can also populate the external sector of the lagoon where they are important components of the living assemblages such as $A$. beccarii, C. gerthi, B. elongata/B. gibba, E. complanatum, Q. lata and S. vivipara but are absent in inner lagoonal areas. Some species dominate the living assemblages (and the total one) in protected lagoonal harbor areas near the lagoon entrance such as B. ordinaria and $N$. stella. Some species are fingerprints of the lagoon outflow influencing the inner to mid shelf such as $P$. mediterranensis, B. pseudoplicata and C. jeffreysii. Species like R. concava, $L$. ocbracea, Q. seminula, G. praegeri, P. haynesi, R. helgolandica and R. gonzalezi populate the lagoon inlet under active and very strong tidal currents due to their ability to survive in environments with unstable substrate.

Appendices 1-7 are attached as supplementary materials (SM1-SM7) in: http://www.e-publicacoes.uerj.br/index.php/jse/article/view/39308

\section{Acknowledgment}

The authors also would like to thank the financial support given by the Fundação para a Ciência e a Tecnologia, FCT, Portugal (grant number UID/GEO/04035/2013) and to Conselho Nacional de Desenvolvimento Científico e Tecnológico, CnPQ, Brazil (grant number: 301588/2016-3). The authors also would like to thank Professor Cristina Carapito Krausshar for her remarkable support.

\section{References}

Abrantes, I., Magalhães, F., Dias, J. M. A., 1994. Characterisation of the surface sediments of the continental shelf and upper slope between Espinho and Aveiro. Gaia 8, 97-104.

Abu-Zied, R.H., Keatings, K.W., Flower, R.J., 2007. Environmental controls on foraminifera in Lake Qarun Egypt. Journal of Foraminiferal Research 37, 136-149. https://doi.org/10.2113/gsifr.37.2.136

Alavi, S.N., 1988. Late Holocene deep-sea benthic foraminifera from Sea of Marmara. Marine Micropalaeontology 13, 213 237. https://doi.org/10.1016/0377-8398(88)90004-7

Almogi-Labin, A., Perelis-Grossovicz, L., Raab, M., 1992. Living Ammonia from a hypersaline inland pool, deep-sea area, Israel.
Journal of Foraminiferal Research 22, 257-266. https://doi.org/10.2113/gsjfr.22.3.257

Alve, E., 2003. A common opportunistic foraminiferal species as an indicator of rapidly changing conditions in a range of environments. Estuarine, Coastal and Shelf Science 57, 501514. https://doi.org/10.1016/S0272-7714(02)00383-9

Alve, E., 1999. Colonization of new habitats by benthic foraminifera: a review. Earth-Science Reviews 46, 67-185. https://doi.org/10.1016/S0012-8252(99)00016-1

Alve, E., Murray, J.W., 1994. Ecology and taphonomy of benthic foraminifera in a temperate mesotidal inlet. Journal of Foraminiferal Research 24 (1), 18-27. https://doi.org/ 10.2113/gsjfr.24.1.18

Alve, E., 1990. Variations in estuarine Foraminiferal biofacies with diminishing oxygen conditions in Drammensfjord, S.E. Norway. In: Hemleben, C. et al. (Eds.), Paleoecology, Biostratigraphy, Paleoceanography and Taxomomy of Agglutinated Foraminifera. Kluwer Academic Publishers. Printed in the Netherlands, pp. 661- 694.

Alve, E., Nagy, J. 1986. Estuarine foraminiferal distribution in Sandebukta, a branch of the Oslo Fjord. Journal of Foraminiferal Research $16 \quad$ (4), 261-284. https://doi.org/10.2113/gsjfr.16.4.261

Anderson, G.J., 1963. Distribution patterns of recent foraminifera of the Bering Sea. Micropalaeontology 9 (3), 305-317.

Armstrong, H., Brasier, M., 2005. Microfossils. Blackwell Publishing, $291 \mathrm{p}$.

Armynot du Châtelet, E., Bout-Roumazeilles, V., Riboulleau, A., Trentesaux, A., 2009. Sediment (grain size and clay mineralogy) and organic matter quality control on living benthic foraminifera. Revue de Micropaléontologie 52, 75-84. https://doi.org/10.1016/10.1016/j.revmic.2008.10.002

Armynot du Châtelet, E., Francescangeli, F., Bouchet, V.M.P., Frontalini, F., 2018. Benthic foraminifera in transitional environments in the English Channel and the southern North Sea: A proxy for regional-scale environmental and paleoenvironmental characterisations. Marine Environmental Research 137, 37-48. https://doi.org/10.1016/j.marenvres. 2018.02.021

Atkinson, K., 1969. The association of living foraminifera with algae from the littoral zone, south Cardigan Bay, Wales. Journal of Natural History 3, 517-542. https://doi.org/10.1080/ 00222936900770451

Bergen, F.W., O’Neil, P., 1979. Distribution of Holocene foraminifera in the Gulf of Alaska. Journal of Paleontology 53 (6), 1267-1292.

Bermúdez, P.J., Seiglie, G.A., 1963. Estudio sístematico de los foraminíferos del Golfo de Cariaco. Boletín del Instituto Oceanográfico de Venezuela 2 (2), 3-267.

Bernhard, J.M., Sen Gupta, B.K. 1999. Foraminifera of oxygendepleted environments. In: Sen Gupta, B.K. (ed.), Modern Foraminifera. Kluwer Academic Publishers, pp. 201-216.

Bernhard, J.M., 1993. Experimental and field evidence of Antarctic foraminiferal tolerance to anoxia and hydrogen sulfide. Marine Micropaleontology 20, 203-213. https://doi.org/ 10.1016/0377-8398(93)90033-T

Bernhard, J., 1989. The distribution of benthic foraminifera with respect to oxygen concentration and organic carbon levels in shallow-water Antarctic sediments. Limnology and 
Oceanography 34

(6),

https://doi.org/10.4319/lo.1989.34.6.1131

Bladin, P., 1986. Bioindicateurs et diagnostic des systèms écologiques. Bulletin d'Ecologie 17, 215-307.

Boltovskoy, E., Giussani, G., Watanabe, S., Wright, R., 1980. Atlas of benthic shelf foraminifera of the Southwest Atlantic. Dr. W. Junk b.v., Publishers, The Hague, 147 pp., pl. 36.

Boltovskoy, E., 1957. Los Foraminiferos del Estuario de Rio de la Plata y su zona de influencia. Revista del Instituto Nacional de Investigación de las Ciencias Naturales y Museu Argentino de Ciencias Naturales "Bernardino Rivadavia", Ciencias Geológicas 6 (1), 1-77.

Borrego, C., Pinho, P., Costa, F., Cardoso da Silva, M., 1990. The Case Study of Ria de Aveiro. Draft report, GRIA, Aveiro, 61 pp.

Bradshaw, J. S., 1961. Laboratory experiments on the ecology of foraminifera. Contributions from the Cushman Foundation for Foraminiferal Research 12 (3), 87-106.

Brönnimann, P., Whittaker, J.E., 1990. Revision of the Trochamminacea and Remaneicacea of the Plymouth District, S. W. England, described by Heron-Allen and Earland (1930). In: Hemleben, C. et al. (Eds.), Paleoecology, Biostratigraphy, Paleoceanography and Taxonomy of Agglutinated Foraminifera. Kluwer Academic Publishers, Netherlands, pp. $105-137$.

Brönnimann, P., Whittaker, J. E., 1988. The Trochamminacea of the Discovery Reports. A Review of the Trochamminacea (Protozoa: Foraminiferida) described from South Atlantic and Antarctic Waters by Heron-Allen and Earland (1932) and Earland (1933, 1934, 1936). British Museum (Natural History), 152 p.

Brönnimann, P., Whittaker, J.E., 1986. On the morphology of Paratrochammina (Lepidotrochammina) haynesi (Atkinson) from south Cardigan Bay, Wales, and validation of Paratrochammina (Lepidotrochammina) Brönnimann, P. and Whittaker, J.E. Revue de Paéobiologie 5, 117-125.

Brönnimann, P., Zaininetti, L., 1984. Agglutinated foraminifera mainly Trochaminacea from the Baia de Sepetiba, near Rio de Janeiro, Brasil. Revue de Paléobiologie 3, 63-115.

Brönnimann, P., Whittaker, J.E., 1983. Deuterammina (Lepidoeuterammina) subgen. Nov., and a redescription of Rotalina ochacea Williamson (Protozoa: Foraminiferida). Bulletin of the British Museum (Natural History), Zoology series, Miscelanea, London, England, 5 (5), 236 p.

Brönnimann, P., Zaninetti, L., Whittaker, J., 1983. On the classification of the Trochaminacea (Foraminiferida). Journal of Foraminiferal Research 13 (3), 202-218.

Brônnimann, P., 1978. Recent benthonic foraminifera from Brazil. Morphology and ecology. Part III. Notes on Asterotrochammina Bermúdez and Seiglie. Notes Laboratoire Paleontologie Universite Geneve 3, 1-8.

Buzas, M.A, Culver, S.J., Jorissen, F.J., 1993. A statistical evaluation of the microhabitats of living (stained) infaunal benthic foraminifera. Marine Micropalaeontology 20, 311-320. https://doi.org/10.1016/0377-8398(93)90040-5

Cairns, J. Jr., Pratt, J.R., 1993. A history of biological monitoring using benthic macroinvertebrates. In: Rosenberg, D.M., Resh, V.H. (Eds.), Freshwater biomonitoring and benthic macroinvertebrates, New York: Chapman and Hall, pp. 10-27.

Camacho, S., Moura, D., Connor, S. Scott, D., Boski. T., 2015. Ecological zonation of benthic foraminifera in the lower Guadiana Estuary (southeastern Portugal). Marine
RESEARCH PAPER Micropaleontology 114, 1-18. https://doi.org/10.1016/ j.marmicro.2014.10.004

Camacho, S., 2012. Ecologic zonation model of the benthic foraminifera and thecamoebians of the Guadiana River Estuary and application in paleoenvironmental reconstruction. PhD thesis, Algarve University.

Caralp, M.H., 1989. Abundance of Bulimina exilis and Melonis barleeanum: relationship to the quality of marine organic matter. Geo-Marine Letters 9, 37-43. https://doi.org/10.1007/BF02262816

Caralp, M., Lamy, A., Pujos, M., 1970. Contribution a la connaissance de la distribution bathymetrique des foraminiferes dans le Golfe de Gascogne. Revista Española de Micropaleontología 2 (1), 55-84.

Caruso, A., Cosentino, C., Tranchina, L., Brai, M., 2011. Response of benthic foraminifera to heavy metal contamination in marine sediments (Sicilian coasts, Mediterranean Sea). Chemistry and Ecology 27, 9-30. https://doi.org/ 10.1080/02757540.2010.529076

Charrieau, L. M., Filipsson, H. L., Ljung, K., Chierici, M., Knudsen, K. L, Kritzberg, E., 2018. The effects of multiple stressors on the distribution of coastal benthic foraminifera: A case study from the Skagerrak-Baltic Sea region. Marine Micropaleontology 139, 42-56. https://doi.org/10.1016/ j.marmicro.2017.11.004

Colom, G., 1974. Foraminiferos ibericos. Intruducción al estudio de las espécies bentónicas recientes. Investigacion Pesquera, Consejo Superior de Investigaciones Científicas. Patrono Juán de la Cierva, Barcelona, vol. 38.

Contreras-Rosales, L.A., Koho, K.A., Duijnstee, I.A.P., De Stigter, H.C., García, R., Koning, E. And Epping, E., 2012. Living deep-sea benthic foraminifera from the Cap de Creus Canyon (western Mediterranean): Faunal-geochemical interactions. Deep-Sea Research I, 64, 22-42. https://doi.org/10.1016/ j.dsr.2012.01.010.

Coppa, M.G., Di Tuoro, A., 1995. Preliminary data on the Holocene Foraminifera of the Cilento continental shelf (Tyrrhenian sea). Revista Española de Paleontología 10 (2), 161-174.

Corliss, B.H., Emerson, S., 1990. Distribution of Rose Bengal stained benthic foraminifera from the Nova Scotia continental margin and Gulf of Maine. Deep Sea Research Part A. Oceanographic Research Papers 37, 381-400. https://doi.org/10.1016/0198-0149(90)90015-N

Cosentino, C., Pepe, F., Scopelliti, G., Calabro, M., Caruso, A., 2013. Benthic foraminiferal response to trace element pollution, the case study of the Gulf of Milazzo, NE Sicily (Central Mediterranean Sea). Environmental Monitoring and Assessment 185, 8777-8802. https://doi.org/10.1007/s10661013-3292-2

de Stigter, H.C., Jorissen, E.J., van der Zwaan, G.J., 1998. Bathymetric distribution and microhabitat partionating of live (Rose Bengal Stained) benthic foraminifera along a shelf to bathyal transect in the southern Adriatic Sea. Journal of Foraminiferal Research 28 (1), 40-65.

de Stigter, H.C., Jorissen, F.J., van der Zwaan, G.J., 1996. Bathymetric distribution an microhabitat partitioning of live (Rose Bengal stained) benthic foraminifera along a shelf to deep sea transect in the southern Adriatic Sea. In: de Stigter, H.C. (Ed.), Recent and Fossil Benthic Foraminifera in the 
Adriatic Sea: Distribution Patterns in Relation to Organic Flux and Oxygen Concentration at the Seabed, Geologica Ultraiectina 144, 39-69.

de Rijk, S., Jorissen, F.J., Rohling, E.J., Troelstra, S.R., 2000. Organic flux control on bathymetric zonation of Mediterranean benthic foraminifera. Marine Micropaleontology 40, 151-166. https://doi.org/10.1016/ S0377-8398(00)00037-2

de Rijk, S., 1995. Salinity control on the distribution of salt-marsh foraminifera (Great Marshes, Massachusetts). Journal of Foraminiferal Research 25, 156-166. https://doi.org/ 10.2113/ gsjfr.25.2.156

de Rijk, S., Troelstra, S. R., 1997. Salt marsh foraminifera from the Great Marshes, Massachusetts: environmental controls. Palaeogeography, Palaeoclimatology, Palaeoecology 130, 81112. https://doi.org/10.1016/S0031-0182(96)00131-9

Debenay, J.-P., Marchand, C., Molnar, N., Aschenbroich, A. Meziane, T., 2015. Foraminiferal assemblages as bioindicators to assess potential pollution in mangroves used as a natural biofilter for shrimp farm effluents (New Caledonia). Marine Pollution Bulletin 93, 103-120. https://doi.org/10.1016/ j.marpolbul.2015.02.00

Debenay, J.-P., Guillou, J.-J., 2002. Ecological transitions indicated by foraminiferal assemblages in paralic environments. Estuaries 25, 1107-1120. https://doi.org/10.1007/ BF02692208

Debenay, J.-P., Tsakiridis, E., Soulard, R., Grosseld, H., 2001. Factors determining the distribution of foraminiferal assemblages in Port Joinville Harbor (Ile d'Yeu, France): the influence of pollution. Marine Micropaleontology 43 (1-2), 75-118.

Debenay, J.-P., Guillou, J.-J., Redois, F., Geslin, E., 2000. Distribution trends of foraminiferal assemblages in paralic environments: a base for using foraminifera as bioindicators. In: Martin, R.E. (Ed.), Environmental Micropaleontology: The Application of Microfossils to Environmental Geology. Kluwer Academic/Plenum Publishers, New York, pp. 39-67.

Debenay, J-P., Pawlowski, J., Decrouez, D., 1996. Les foraminifères actuels. Masson, Paris, 329 p.

Debenay, J-P. 1978. Distribution des foraminiferes vivants et des tests vides en Baie de Bourgneuf. These présentée pour obtention du diplome de docteur de 3 ème Cycle à l'Université Pierre et Marie Currie, Paris, 193 pp., 18 pls.

Dessandier, P.-A., Bonnin, J., Kim, J.-H., Racine, C., 2018. Comparison of living and dead benthic foraminifera on the Portuguese margin: Understanding the taphonomical processes. Marine Micropaleontology 140, 1-16. https://doi.org/10.1016/j.marmicro.2018.01.001

Dessandier, P.-A., Bonnin, J., Kim, J.-H., Bichon, S., Deflandre, B., Grémare, A., Damsté, J.S., 2016. Impact of organic matter source and quality on living benthic foraminiferal distribution on a river-dominated continental margin: a study of the Portuguese margin. Journal of Geophysical Research, Biogeosciences 121, 1689-1714. https://doi.org/10.1002/ 2015JG003231

Dessandier, P.-A., Bonnin, J., Kim, J.-H., Bichon, S., Grémare, A., Deflandre, B., De Stigter, H., Malaizé, B., 2015. Lateral and vertical distributions of living benthic foraminifera off the Douro River (western Iberian margin): impact of the organic
RESEARCH PAPER matter quality. Marine Micropaleontology 120, 31-45. https://doi.org/10.1016/j.marmicro.2015.09.002

Dias, J.M., 2001. Contribution to the study of the Ria de Aveiro hydrodynamics. PhD Thesis, Universidade de Aveiro, 288 pp.

Dias, J.M., Lopes, J.F., Dekeyser, I., 2000. Tidal propagation in the Aveiro lagoon, Portugal. Physics and Chemistry of the Earth (B) 25 (4), 369-374.

Dias, J.M., Lopes, J.F., Dekeyser, I., 1999. Hydrological characterization of the Ria de Aveiro, Hydrological characterisation of Ria de Aveiro, Portugal, in early summer. Oceanologica Acta 22 (5), 473-485.

Dias, J.M.A., 1987. Dinâmica sedimentar e evolução recente da plataforma continental portuguesa setentrional. PhD Thesis, Universidade de Lisboa, 500 pp.

Dias, J.M.A., Nittrouer, C.A., 1984. Continental shelf sediments of northern Portugal. Continental Shelf Research 3 (2), 147-165. https://doi.org/10.1016/0278-4343(84)90004-9

Disaró, S.T., 2014. Caracterização da plataforma continental da Bacia de Campos (Brasil, SE) fundamentada em foraminíferos bentônicos recentes. PhD Thesis, Universidade Federal do Rio Grande do Sul, Brazil.

Duleba, W., Teodoro, A.C., Debenay, J-P, Alves Martins M.V., Gubitoso, S., Pregnolato, L.A., Lerena, L.M., Prada, S. M., Bevilacqua, J. E., 2018. Environmental impact of the largest petroleum terminal in SE Brazil: A multiproxy analysis based on sediment geochemistry and living benthic foraminifera. PLoS ONE 13(2): e0191446. https://doi.org/10.1371/ journal.pone.0191446

Duleba, W., Coimbra, J.C.S., Petri, S., Barbosa, C.F. 2005. Foraminíferos, tecamebas e ostracodes recentes utilizados como bioindicadores em estudos ambientais brasileiros. In: Souza, C.R.G.; Suguio, K., Oliveira, A.M.S., Oliveira, P.E. (eds.), Quaternário do Brasil, Ribeirão Preto, Holos, pp. 176-210.

Duleba, W., Debenay, J.P., 2003. Hydrodynamic circulation in the estuaries of estação ecológica Juréia-Itatins, Brazil, inferred from foraminifera and thecamoebian assemblages. Journal of Foraminiferal Research 33, 62-93. https://doi.org/ $10.2113 / 0330062$

Earland, A., 1934. Foraminifera. Part III. The Falklands sector of the Antarctic (excluding South Georgia). "Discovery" Reports. issue by the Discovery Committee, Colonial Office, London. Cambridge, England, University Press, 10, 1-208.

El Naby, A.A., Al Menoufy, S., Gad, A., 2018. Benthic foraminiferal assemblages as bio-indicators of metals contamination in sediments, Qarun Lake as a case study, Egypt. Journal of African Earth Sciences 139, 96-112. https://doi.org/10.1016/j.jafrearsci.2017.12.001

Ellis, B.F., Messina, A.R., 1942-2008. Catalogue of Foraminifera. Micropaleontology Press Micropaleontology Press.

Enge, A.L., Kucera, M., Heinz, P., 2012. Diversity and microhabitats of living benthic foraminifera in the abyssal Northeast Pacific. Marine Micropaleontology 96-97, 84-104. https://doi.org/10.1016/j.marmicro.2012.08.004

Fatela, F. Moreno, J., Leorri, E., Corbett, R., 2014. High marsh foraminiferal assemblages' response to intra-decadal and multidecadal precipitation variability, between 1934 and 2010 (Minho, NW Portugal). Journal of Sea Research 93: 118-132.

Fatela, F., Moreno, J., Antunes, C., 2007. Salinity influence on foraminiferal tidal marsh assemblages of NW Portugal: an anthropogenic constraint? Thalassas 23 (1), 51-63. 
Geslin, E., Debenay, J.-P., Duleba, W., Bonetti, C., 2002. Morphological abnormalities of foraminiferal tests in Brazilian environments: comparison between polluted and non-polluted areas. Marine Micropaleontology 45, 151-168.

Gu, Y., Liu, H., Qin, Y., 2017. Postglacial transgression maximum documented by the core sediments of Xixi Wetland, East China. Quaternary International 436, 84-95. https://doi.org/10.1016/j.quaint.2016.10.030

Guo, Q., Li, B., Kim, J.-K., 2017. IODP Expedition 339 Scientists. Benthic foraminiferal assemblages and bottom water evolution off the Portuguese margin since the Middle Pleistocene. Global and Planetary Change 150, 94-108 https://doi.org/ 10.1016/j.gloplacha.2016.11.004

Hasegawa, S., 1988. Distribution of recent foraminiferal fauna in Toyama Bay, Central Japan. Revue de Paléobiologie, Benthos '86, Vol. Spéc. n. ' 2, Genève, pp. 803-813.

Hayward, B.W., Le Coze, F., Gross, O., 2018. World Foraminifera Database, Worms. Accessed through: World Register of Marine Species at: http://www.marinespecies.org/ aphia.php? $\mathrm{p}=$ taxdetailsandid $=112981$ on 2018-03-11

Hayward, B.W., Triggs, C.M.,1994. Computer analysis of benthic foraminiferal associations in a tidal New Zealand inlet. Journal of Micropaleontology 13, 103-117. https://doi.org/10.1144/ jm.13.2.103

Hedley, R.H., Hurdle, C.M., Burdett, I.D.J., 1967. The marine fauna of New Zealand: intertidal foraminifera of the Corallina officinalis Zone. New-Zealand Oceanographic Institute, Wellington, Memoire 38, 9-48, 7 pl.

Hermelin, J.O.R., 1987. Distribution of Holocene benthic foraminifera in the Baltic Sea. Journal of Foraminiferal Research 17 (1), 62-73.

Hermelin, J.O.R., Scott, D.B., 1985. Recent benthic foraminifera from the central North Atlantic. Micropaleontology, 31 (3), 199-220.

Hermelin, J.O.R., 1983. Biogeographic patterns of modern Reophax dentaliniformis Brady (arenaceous benthic foraminifera) from the Baltic Sea. Journal of Foraminiferal Research,13 (3), 155-162.

Heron-Allen, E., Earland, A., 1911. On the Recent and Fossil Foraminifera of the shore-sands of Selsey-Bill, Sussex; Part VII, suppl. Journal of the Royal Microscopical Society, London, pp. 298-343.

Höglund, H., 1947. Foraminifera in the Gullmar Fjord and the Skagerak. Zoologiska Bidrag från Uppsala 26, 328 pp.

Horton, B.P., Whittaker, J.E., Thomson, K.H., Hardbattle, M.I.J., Kemp, A., Woodrffe, S.A., Wright, M.R., 2005. The development of modern foraminiferal data set for sea- level reconstructions, Wakatobi Marine National Park, southeast Sulawesi, Indonesia. Journal of Foraminiferal Research 35, 1 14. https://doi.org/10.2113/35.1.1

Jones, R.W., Charnock, M.A., 1985. Morphogroups of agglutinated foraminifera. Their life positions and feeding habits and potential applicability in (paleo)ecological studies. Revue de Paleobiologie 4(2), 311-320.

Jorissen, F.J., De Stigter, H.C., Widmark, J.G., 1995. A conceptual model explaining benthic foraminiferal microhabitats. Marine Micropaleontology 26, 3-15.

Knight, R., Mantoura, R.F.C., 1985. Chlorophyll and carotenoid pigments in Foraminifera and their symbiotic algae: analysis by high performance liquid chromatography. Marine Ecology Progress Series 23, 241-249.
RESEARCH PAPER

Koho, K.A., García, R., De Stigter, H.C., Epping, E., Koning, E., Kouwenhoven, T.J., Van Der Zwaan, G.J., 2008. Sedimentary labile organic carbon and pore water redox control on species distribution of benthic foraminifera: A case study from Lisbon-Setúbal Canyon (southern Portugal). Progress in Oceanography 79, 55-82.

Koho, K. A., Kouwenhoven, T. J., de Stigter, H. C., van der Zwaan, G. J., 2007. Benthic foraminifera in the Nazaré Canyon, Portuguese continental margin: Sedimentary environments and disturbance. Marine Micropaleontology 66, 27-51.

Langer, M.R., Leppig, U., 2000. Molecular phylogenetic status of Ammonia catesbyana (D’Orbigny, 1839), an intertidal foraminifer from the North Sea. Neues Jahrbuch fur Geologie und Palaontologie Monatshefte 9(9), 545-556

Laut, L.L.M., Clemente, I.M.M.M., Belart, P., Martins, M.V.A., Frontalini, F., Laut, V.M., Gomes, A., Boski, T., Lorini, M. L., Fortes, R. R. And Rodrigues, M. A. C., 2016. Multiproxies (benthic foraminifera, ostracods and biopolymers) approach applied to identify the environmental partitioning of the Guadiana River Estuary (Iberian Peninsula). Journal of Sedimentary Environments 1(2), 184-201.

Leorri, E., Fatela, F., Cearreta, A., Moreno, J., Antunes, C., Drago, T., 2011. Assessing the performance of a foraminifera-based transfer function to estimate sea-level changes in northern Portugal. Quaternary Research 75, 278-287.

Levy, A., Mathieu, R., Poignant, A., Rosset-Moulinier, M., Ubaldo, M.L., Lebreiro, S., 1995. Foraminiferes actuels de la marge continentale portuguaise-inventaire et distribution. Memórias do Instituto Geológico e Mineiro, Lisbon, 32 p.

Levy, A., Mathieu, R., Poignant, A., Rosset-Moulinier, M., Ubaldo, M.L., Ambroise, D., 1993. Recent foraminifera from the continental margin of Portugal. Micropaleontology 39 (1), 75-87.

Levy, A., Mathieu, R., Momeni, I., Poignant, A., Rosset-Moulinier, M., Rovillois, A., 1974. Les représentants des Ammodiscacea, Lituolacea, Nodosariacea, Buliminacea (Foraminifères) dans les sables des plages de Dunkerque. Remarques sur les espéces signalées par O. Terquem. Revue de Micropaléontologie 17, 127-133.

Li, Z.-Y., Liu, D.-S, Long, H.-Y., 2014. Living and dead benthic foraminifera assemblages in the Bohai and northern Yellow Seas: Seasonal distributions and paleoenvironmental implications. Quaternary International 349, 113-126. https://doi.org/10.1016/j.quaint.2014.05.019

Lin, J., 1992. Palaeoecology, Palaeoclimate and Palaeogeography of Quaternary Foraminiferal Faunas in China. PhD Thesis, Free University of Brussels, 152 p.

Livingstone, D.R., 1993. Biotechnology and pollution monitoring: Use of molecular biomarkers in the aquatic environment. Journal of Chemical Technology and Biotechnology 57, 195-211.

Lopes, J.F., Cardoso, A.C., Moita, M. T., Rocha, A.C., Ferreira, J.A., 2009. Modelling the temperature and the phytoplankton distributions at the Aveiro near coastal zone, Portugal. Ecological Modelling 220, 940-961.

Lübbers, J., Schönfeld, J., 2018. Recent saltmarsh foraminiferal assemblages from Iceland. Estuarine, Coastal and Shelf Science 200, 380-394. https://doi.org/10.1016/j.ecss.2017.11.019

Magalhães, F., 1999. Os sedimentos da plataforma continental portuguesa: contrastes espaciais, perspectiva temporal, 
potencialidades económicas. PhD Thesis, Universidade de Lisboa (Portugal), 289 pp.

Majewski, W., Wellner, J.S., Szczuciński, W., Anderson, J.B., 2012. Holocene oceanographic and glacial changes recorded in Maxwell Bay, West Antarctica. Marine Geology 326-328, 6779. https://doi.org/10.1016/j.margeo.2012.08.009

Mangoni, O., Aiello, G., Balbi, S., Barra, D., Bolines, F., Donadio, C., Ferrara, L., Guida, M., Paris, R., Pennetta, M., Trifuoggi, M., Arienzo, M., 2016. A multidisciplinary approach for the characterization of the coastal marine ecosystems of Monte Di Procida (Campania, Italy). Marine Pollution Bulletin 112, 443 451. https://doi.org/10.1016/j.marpolbul.2016.07.008

Martins, M.V.A., Hohenegger, J., Frontalini, F., Alveirinho Dias, J.M., Geraldes, M.C., Rocha, F., 2019. Dissimilarity between living and dead benthic foraminiferal assemblages in the Aveiro Continental Shelf (Portugal). PlosOne, https://doi.org/10.1371/journal.pone.0209066.

Martins, M.V.A., Moreno, J.C., Miller, P. I., Miranda, P., Laut, L., Pinheiro, A. E. P., Yamashita, C., Terroso, D. L., Rocha, F., Bernardes, C., 2017. Biocenoses of benthic foraminifera of the Aveiro Continental Shelf (Portugal): influence of the upwelling events and other shelf processes. Journal of Sedimentary Environments 2 (1), 9-34. http://dx.doi.org/ 10.12957/jse.2017.28041

Martins, M.V.A., Pinto, A.F., Frontalini, F., Machado da Fonseca, M.C., Terroso, D.L., Laut, L.L.M., Zaaboub, N., Rodrigues, M.A.C., Rocha, F., 2016 a. Can benthic foraminifera be used as bio-indicators of pollution in areas with a wide range of physicochemical variability? Estuarine, Coastal and Shelf Science 182, 211-225. http://dx.doi.org/10.1016/ j.ecss.2016.10.011

Martins, M.V.A., Hohenegger, J., Frontalini, F., Miranda, P., Rodrigues, M.A.C., Dias, J.M.A., 2016 b. Comparison between the dead and living benthic foraminiferal assemblages in Aveiro Lagoon (Portugal). Palaeogeography, Palaeoclimatology, Palaeoecology 455 (1), 16-32. http://dx.doi.org/10.1016/j.palaeo.2016.05.003

Martins, M.V.A., Victor Quintino, V., Tentúgal, R.M., Frontalini, F., Miranda, P., Laut, L.L.M., Martins, R., Rodrigues, A.M., 2015 a. Characterization of bottom hydrodynamic conditions on the central western Portuguese continental shelf based on benthic foraminifera and sedimentary parameters. Marine Environmental Research 109, 52-68. http://dx.doi.org/ $.1016 /$ j.marenvres.2015.06.006

Martins, V.A., Silva, F., Lazaro, L.M.L., Frontalini, F., Clemente, I.M., Miranda, P., Figueira, R., Sousa, S.H.M., Dias, J.M.A., 2015 b. Response of benthic foraminifera to organic matter quantity and quality and bioavailable concentrations of metals in Aveiro Lagoon (Portugal). PLoS ONE 10 (2): e0118077. https://doi.org/10.1371/journal.pone.0118077

Martins, M.V.A., Frontalini, F., Rodrigues, M.A.C., Dias, F.A., Laut, L.L.M., Silva, F. S., Clemente, I. M.M.M., Reno, R., Moreno, J., Sousa, S., Zaaboub, N., El Bour, M., Rocha, F., 2014. Foraminiferal biotopes and their distribution control in Ria de Aveiro (Portugal): a multiproxy approach. Environmental Monitoring and Assessment 186 (12), 88758897. https://doi.org/10.1007/s10661-014-4052-7

Martins, V. A. Frontalini, F., Tramonte, K. M., Figueira, R. C. L., Miranda, P., Sequeira, C., Fernández-Fernández, S., Dias, J.A., Yamashita, C., Laut, L. M., Sobrinho, F., Rodrigues, M. A.,
Bernardes, C., Nagai, R., Sousa, S. M., Mahiques, M., Rubio, B., Bernabeu, A., Rey, D., Rocha, F., 2013. Assessment of the health quality of Ria de Aveiro (Portugal): heavy metals and benthic foraminifera. Marine Pollution Bulletin 70, 18-33. http://dx.doi.org/10.1016/j.marpolbul.2013.02.003

Martins, V., Abrantes, I., Grangeia, C., Martins, P., Nagai, R., Sousa, S. H.M., Laut, L.L.M., Dias, J. M. A., Silva, E. F., Rocha, F., 2012. Records of sedimentar dynamics in the continental shelf and upper slope between Aveiro-Espinho ( $\mathrm{N}$ Portugal). Journal of Marine Systems 96, 48-60. http://dx.doi: 10.1016/j.jmarsys.2012.02.001

Martins, V., Ferreira da Silva, E., Sequeira, C., Rocha, F., Duarte, A.C., 2010. Evaluation of the ecological effects of heavy metals on the assemblages of benthic foraminifera of the canals of Aveiro (Portugal). Estuarine, Coastal and Shelf Science 87, 293-304. http://dx.doi:10.1016/j.ecss.2010.01.011.

Mathieu, R., 1986. Sediments et Foraminiferes actuels et ressurgences cotieres sur la marge continentale Atlantique du Maroc: living foraminifera and upwelling on the Atlantic Continental Margin of Morocco. Revue de Paléobiologie, Benthos'86, International Symposium Benthic Foraminifera, Vol. Spéc. n. ${ }^{\circ}$ 2, Genève, pp. 845-850.

Mello e Sousa, S.H., Yamashita, C., Nagai, R.H., Martins, M.V.A., Ito, C., Vicente, T., Taniguchi, N., Burone, L., Fukumoto, M., Aluizio, R., Koutsoukos, E.A.M., 2017. Foraminíferos bentônicos no talude continental, Platô de São Paulo e cânions da Bacia de Campos. In: Falcão, A.P.C., Lavrado, H.P. (Eds), Ambiente Bentônico: caracterização ambiental regional da Bacia de Campos, Atlântico Sudoeste, Rio de Janeiro: Elsevier, Habitats 3, 111-144. https://doi.org/10.1016/B978-85-3527263-5.50005-9

Mendes, I., Gonzalez, R., Dias, J. M. A., Lobo, P., Martins, V., 2004. Factors influencing recent benthic foraminifera distribution on the Guadiana shelf (Southwestern Iberia). Marine Micropaleontology 51, 171-192. https://doi.org/ 10.1016/j.marmicro.2003.11.001

Mendes, I., Rosa, F., Dias, J.A., Schönfeld, J., Ferreira, Ó., Pinheiro, J., 2010. Inner shelf paleoenvironmental evolution as a function of land-ocean interactions in the vicinity of the Guadiana River, SW Iberia. Quaternary International 221, 5867. https://doi.org/10.1016/j.quaint.2009.10.037

Moita, M.T., 2001. Estrutura, Variabilidade e Dinâmica do Fitoplâncton na Costa de Portugal Continental. PhD Thesis, Faculdade de Ciências da Universidade de Lisboa, 272 pp.

Mojtahid, M., Jorissen, F., Lansard, B., Fontanier, C., Bombled, B., Rabouille, C., 2009. Spatial distribution of live benthic foraminifera in the Rhône prodelta: Faunal response to a continental-marine organic matter gradient. Marine Micropaleontology 70, 177-200. https://doi.org/10.1016/ j.marmicro.2008.12.006

Mojtahid, M., Jorissen, F., Pearson, T.H., 2008. Comparison of benthic foraminiferal and macrofaunal responses, to organic pollution in the Firth of Clyde (Scotland). Marine Pollution Bulletin 56, 42-76. https://doi.org/10.1016/j.marpolbul. 2007.08.018

Moodley, L., van der Zwaan, G.J., Herman, P.M.J., Kempers, L., van Breugel, P., 1997. Differential response of benthic meiofauna to long-term anoxia with special reference to Foraminifera (Protista: Sarcodina). Marine Ecology Progress Series 158, 151-163. 
Moreno, J., Fatela, F., Leorri, E., De La Rosa, J.M., Medeiros, A. 2014. Marsh benthic Foraminifera response to estuarine hydrological balance driven by climate variability over the last $2000 \mathrm{yr}$ (Minho estuary, NW Portugal). Quaternary Research 82 (2), 318-330. https://doi.org/10.1016/j.yqres.2014.04.014

Morigi, C., Sabbatini, A., Vitale, G., Pancotti, I., Gooday, A.J., Duineveld, G.C.A., de Stigter, H.C., Danovaro, R., Negri, A., 2012 Foraminiferal biodiversity associated with cold-water coral carbonate mounds and open slope of SE Rockall Bank (Irish continental margin-NE Atlantic). Deep Sea Research Part I Oceanographic Research Papers 59. 54-71. https://doi.org/10.1016/j.dsr.2011.10.004

Müller-Navarra, K., Milker, Y., Schmiedl, G., 2016. Natural and anthropogenic influence on the distribution of salt marsh foraminifera in the Bay of Tümlau, German North Sea. Journal of Foraminiferal Research 46, 61-74. https://doi.org/ 10.2113/gsjfr.46.1.61

Murray, J., 2006. Ecology and applications of benthic foraminifera. Cambridge University Press, p. 426.

Murray, J.W., Alve, E., 2011. The distribution of agglutinated foraminifera in NW European seas: baseline data for the interpretation of fossil assemblages. Palaeontologia Electronica 14 (2), 1-41.

Murray, J., Alve, E., 1999a. Taphonomic experiments on marginal marine foraminiferal assemblages: how much ecological information is preserved? Palaeogeography, Palaeoclimatology, Palaeoecology 149, 183-197. https://doi.org/ 1010.1016/S0031-0182(98)00200-4

Murray, J.W., Alve, E., 1999b. Natural dissolution of modern shallow water benthic foraminifera: taphonomic effects on the palaeoecological record. Palaeogeography, Palaeoclimatology, Palaeoecology 146, 195-209. https://doi.org/10.1016/S00310182(98)00132-1

Murray, J.W., 1991. Ecology and Palaeoecology of Benthic Foraminifera Longman Scientific and Technical. Harlow, UK.

Murray, J.W., 1971. An Atlas of British Recent Foraminiferids. Heinemann Educ. Books, London, 244 pp., 96 pls.

Murray, J.W., 1970. Living foraminifers of the Western Approaches to the English Channel. Micropalaeontology 16 (4), 471-485.

Nichols, M., Allen, G., 1981. Sedimentary processes in coastal lagoons. In: Coastal Lagoon Research, Present and Future, Proc. Seminar, Duke University Marine Laboratory, Beaufort, NC, USA., UNESCO Technical Papers in Marine Science 33, 27-80.

Peliz, Á., Rosa, T.L., Santos, A., Miguel, P., Pissarra, J.L., 2002. Fronts, jets, and counter-f lows in the Western Iberian upwelling system. Journal of Marine Systems 35, 61-77. https://doi.org/10.1016/S0924-7963(02)00076-3

Perez-Cruz, L.L., Machain-Castillo, M.L., 1990. Benthic foraminifera of the oxygen minimum zone, continental shelf of the Gulf of Tehuantepec, Mexico. Journal of Foraminiferal Research 20 (4), 312-325. https://doi.org/10.2113/gsjfr.20.4.312

Pillet, L., de Vargas, C., Pawlowski, J., 2011. Molecular Identification of Sequestered Diatom. Chloroplasts and Kleptoplastidy in Foraminifera. Protist 162, 394-404. https://doi.org/10.1016/j.protis.2010.10.001

Poag, C.W., 1976. The foraminiferal community of San Antonio Bay. In: Bouma, A. H. (ed.), Shell dredging and its influence on Gulf Coast Environments, Gulf Publication, Houston, pp. 304-336.
RESEARCH PAPER

Polovodova, I., Nikulina, A., Schönfeld, J., Dullo, W.C., 2009. Recent benthic foraminifera in the Flensburg fjord (Western Baltic sea). Journal of Micropalaeontology 28, 131-142.

Pritchard, D.W., 1967. What is an estuary: physical viewpoint. In: Lauff, G.E. (Ed), Estuaries, American Association for Advancement of Science, Publication 83, Washington, 3-5.

Pritchard, D.W., 1989. Estuarine classification - a help or a hindrance. In: Neilson, B.J., Kuo, A., Brubaker, J. (Eds), Estuarine circulation. Humana Press, Clifton, pp. 1-38.

Pujos, M. ,1976. Écologie des foraminifères benthiques et des thecamoebiens de la Gironde et du plateau continental sudGascongne. Aplication à la connaissance du Quaternaire terminal de la région ouest-Gironde. Memoires de l'institute de Geologie du Bassin D’Aquitaine, Bordeaux 8, 274 pp.

Quintela, M., Costa, P.J.M., Fatela, F., Drago, T., Hoska, N., Andrade, C., Freitas, M.C., 2016. The AD 1755 tsunami deposits onshore and offshore of Algarve (south Portugal): Sediment transport interpretations based on the study of Foraminifera assemblages. Quaternary International 408, 123138. https://doi.org/10.1016/j.quaint.2015.12.029

Rathburn, A.E., Corliss, B.H., 1994. The ecology of living (stained) deep-sea benthic foraminifera from the Sulu Sea. Paleoceanography 9 (1), 87-150. https://doi.org/ 10.1029/93PA02327

Redois, F., Debenay, J.-P., 1996. Influence du confinement sur la répartition des foraminiferes benthiques: exemple de l'estran d'une ria mésotidale de Bretagne Méridionale. Revue de Paléobiologie 15 (1), 243-260.

Rhumbler, L., 1938. Foraminiferen aus dem Meeressand von Helgoland, gesammelt von A. Remane (Kiel). Kiel. Meeresforschungen 2, 157-222, 64 text-fig.

Roberts, A., Austin, W., Evans, K., Bird, C., Schweizer, M., Darling, K., 2016. A new integrated approach to taxonomy: the fusion of molecular and morphological systematics with type material in benthic foraminifera. PLoS One 11 (7), e0158754. https://doi.org/10.1371/journal.pone.0158754.

Romano, E., Bergamin, L., Pierfranceschi, G., Provenzani, C., Marassich, A., 2018. The distribution of benthic foraminifera in Bel Torrente submarine cave (Sardinia, Italy) and their environmental significance. Marine Environmental Research 133, 114-127. https://doi.org/10.1016/j.marenvres.2017.12.014

Romano, E., Bergamin, L., Finoia, M. G., Carboni, M. G., Ausili, A., Gabellini, M., 2008. Industrial pollution at Bagnoli (Naples, Italy): Benthic foraminifera as a tool in integrated programs of environmental characterisation. Marine Pollution Bulletin 56, 439-457. https://doi.org/10.1016/j.marpolbul.2007.11.003

Rottgard, D., 1952. Mikropaläotologisch wichtige Bestandteile rezenter brackishe sedimente an der Küsten SchleswigHolsteins. Kiel University, Institute of Geosciences 1, 169-228.

Samir, A.M., El-Din, A.B., 2001. Benthic foraminiferal assemblages and morphological abnormalities as pollution proxies in two Egyptian bays. Marine Micropaleontology 41, 193-227. https://doi.org/10.1016/S0377-8398(00)00061-X

Samir, A.M., 2000. The response of benthic foraminifera and ostracods to various pollution sources: a study from two lagoons in Egypt. Journal of Foraminiferal Research 30, 83-98. https://doi.org/10.2113/0300083

Schmiedl, G., Mackensen, A., 1997. Late Quaternary paleoproductivity and deep-water circulation in the eastern South Atlantic Ocean: evidence from benthic foraminifera. 
Palaeogeography, Palaeoclimatology, Palaeoecology 130, 43 80. https://doi.org/10.1016/S0031-0182(96)00137-X

Schönfeld, J., Alve, E., Geslin, E., Jorissen, F., Korsun, S., Spezzaferri, S. and members of the Fobimo Group, 2012. The FOBIMO (FOraminiferal Bio-MOnitoring) initiative towards a formalised protocol for benthic foraminiferal monitoring studies. Marine Micropaleontology 94-95, 1-13. https://doi.org/10.1016/ j.marmicro.2012.06.001

Schönfeld, J., 2002. Recent benthic foraminiferal in deep highenergy environments from the Gulf of Cadiz (Spain). Marine Micropaleontology 44, 141-162. https://doi.org/10.1016/ S0377-8398(01)00039-1

Schröder-Adams, C., Cole, F., Medioli, F., Mudie, P., Scott, D., Dobbin, L., 1990. Recent arctic shelf foraminifera: seasonally ice covered vs. perennially ice-covered areas. Journal of Foraminiferal Research 20 (1), 8-36. https://doi.org/ 10.2113/gsjfr.20.1.8

Scott, D.B., Schafer, C.T., Medioli, F.S., 2001. Monitoring in coastal environments using foraminifera and thecamoebian indicators. Cambridge University Press, $192 \mathrm{p}$.

Scott, D.B., Medioli, F.S., 1980. Quantitative studies of marsh foraminiferal distributions in Nova Scotia: their implications for the study of sea-level changes. Cushman Foundation for Foraminiferal Research, Special Publication 17, 58 p.

Scott, D.B., Piper, D., Panagos, A., 1979. Recent salt marsh and intertidal mudflat Foraminifera from the western coast of Greece. Rivista Italiana di Paleontologia 85 (1), 243-266.

Scott, D.B., Medioli, F.S., 1978. Vertical zonation of marsh foraminifera as accurate indicators of former sea-level. Nature 272, 538-541.

Seiglie, G.A., 1975. Foraminifers of Guayanilla bay and their use as environmental indicators. Revista Española de Micropaleontología 7, 453-487.

Seiglie, G.A., 1965. New and rare foraminifers from los Testigos reefs, Venezuela. Caribbean Journal of Science, Mayagüez, Puerto Rico, 4 (1964), n. ${ }^{\circ}$ 4, 497-512.

Sen Gupta, B.K., Smith, L.E., 2013. Foraminifera of petroleum platforms, Louisiana shelf, Gulf of Mexico. Marine Micropaleontology 101, 161-179. https://doi.org/10.1016/ j.marmicro.2013.01.001

Sen Gupta, B.K., Machain-Castillo, M.L., 1993. Benthic foraminifera in oxygen-poor habitats. Marine Micropaleontology 20, 183-201. https://doi.org/ 10.1016/0377-8398(93)90032-S

Serandrei-Barbero, R., Carbognin, L., Taroni, G., Cova, E., 1999. Distribution of recent benthic foraminifera in the southern basin of the Venice Lagoon (Italy): Statistical evaluation of taxa significance. Micropaleontology 45 (1), 99-111.

Silva, K.A., Corliss, B.H., Rathburn, A.E., Thunell, R.C., 1996. Seasonality of living benthic foraminifera from the San Pedro Basin, California Borderland. Journal of Foraminiferal Research 26 (1), 71-93. https://doi.org/10.2113/gsjfr.26.1.71

Sliter, W.V., 1970. Inner-neritic Bolivinitidae from the eastern Pacific margin. Micropaleontology 16 (2), 155-174, 8 pls.

Stefanoudis, P.V., Schiebel, R., Mallet, R., Durden, J.M., Bett, B.J., Gooday, A.J., 2016. Agglutination of benthic foraminifera in relation to mesoscale bathymetric features in the abyssal NE

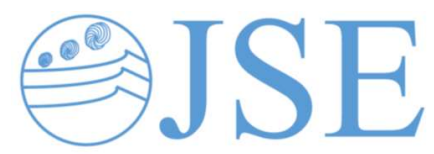

RESEARCH PAPER

Atlantic (Porcupine Abyssal Plain). Marine Micropaleontology 123, 15-28. https://doi.org/10.1016/j.marmicro.2015.12.005

Steinsund, P. I., 1994. Benthic foraminifera in surface sediments of the Barents and Kara Seas: Modern and late Quaternary applications. University of Tromsø, Tromsø, p. 111.

Suhr, S.B., Pond, D.W., 2006. Antarctic benthic foraminifera facilitate rapid cycling of phytoplankton-derived organic carbon. Deep Sea Research Part II: Topical Studies in Oceanography 53 (8-10), 895-902. https://doi.org/10.1016/ j.dsr2.2006.02.00

Swallow, J.E., 2000. Intra-annual variability and patchiness in living assemblages of salt marsh foraminifera from Mill Rythe Creek, Chichester Harbour, England. Journal of Micropaleontology 19 (9), 9-22. https://doi.org/10.1144/jm.19.1.9

van der Zwaan, G.J., Duijnstee, I.A.P., Den Dulk, M., Ernst, S.R., Jannink, N.T., Ouwenhoven, T.J., 1999. Benthic foraminifers: proxies or problems? A review of paleoecological concepts. Earth-Science Reviews 46, 213-236.

Vanney, J.R., Mougenot, D., 1981. La plate-forme continentale du Portugal et les provinces adjacentes: analyse géomorphologique. Memórias dos Serviços de Geologia de Portugal 28, $145 \mathrm{pp}$

Vanney, J. R., Auxietre, J. L., Dunand, J. P., 1979. Geomorphic provinces and evolution of the Northwestern Iberian continental margin. Annales de l'Institut Océanographique 55 (1), 5-20.

Varekamp, J. C., Thomas, E., van de Plassche, O., 1992. Relative sea-level rise and climate change over the last 1500 years. Global Change, SI, 4, 293-304.

Vaz, N., Dias, J.M., Leitão, P.C., 2009. Three-dimensional modelling of a tidal channel: the Espinheiro Channel (Portugal). Continental Shelf Research 29 (1), 29-41. https://doi.org/10.1016/j.csr.2007.12.005

Vilks, G., 1969. Recent foraminifera in the Canadian Arctic. Micropaleontology 15 (1), 35-60.

Vitorino, J.P.N., Oliveira, A.T.C., Jouanneau, J.M., Drago, T., 2002a. Winter dynamics on the northern Portuguese shelf. Part 1: bottom boundary layers and sediment dispersal. Progress in Oceanography 52 (2-4), 129-153. https://doi.org/10.1016/ S0079-6611(02)00003-4

Vitorino, J.P.N., Oliveira, A.T.C., Jouanneau, J.M., Drago, T., $2002 \mathrm{~b}$. Winter dynamics on the northern Portuguese shelf. Part 2: physical processes. Progress in Oceanography, 52 (2-4), 155 170. https://doi.org/10.1016/S0079-6611(02)00004-6

Wells, P., 1985. Recent agglutinated benthonic Foraminifera (suborder Textulariina) of Wellington Harbour, New Zealand. New Zealand Journal of Marine and Freshwater Research 19(4), 575-599.

Williamson, M.A., Keen, C.E., Mudie, P.J., 1984. Foraminiferal distribution on the continental margin off Nova Scotia. Marine Micropaleontology 9, 219-239.

Williamson, W.C., 1858. On the recent foraminifera of Great Britain. London Royal Society 4, 1-107, pl. 1-7, 204 fig.

Yassini, I., Jones B.G., 1995. Foraminiferida and ostracoda from estuarine and shelf environments on the southeastern coast of Australia. Wollong, N. S. W. The University os Wollongong Press, Australia, 484 pp. 